This item was submitted to Loughborough's Research Repository by the author.

Items in Figshare are protected by copyright, with all rights reserved, unless otherwise indicated.

\title{
The financial strength anomaly in the UK: Information uncertainty or liquidity?
}

\section{PLEASE CITE THE PUBLISHED VERSION}

https://doi.org/10.1080/1351847X.2019.1641532

\section{PUBLISHER}

Taylor \& Francis (Routledge)

\section{VERSION}

AM (Accepted Manuscript)

\section{PUBLISHER STATEMENT}

This is an Accepted Manuscript of an article published by Taylor \& Francis in The European Journal of Finance on 25 Jul 2019, available online: https://doi.org/10.1080/1351847X.2019.1641532

\section{LICENCE}

CC BY-NC-ND 4.0

\section{REPOSITORY RECORD}

Kumsta, Rene-Christian, and Andrew Vivian. 2019. "The Financial Strength Anomaly in the UK: Information Uncertainty or Liquidity?”. Loughborough University. https://hdl.handle.net/2134/38249. 


\section{The European Journal of Finance

\section{The Financial Strength Anomaly in the UK: Information Uncertainty or Liquidity?}

\begin{tabular}{|r|l|}
\hline Journal: & The European Journal of Finance \\
\hline Manuscript ID & REJF-2017-0226.R2 \\
\hline Manuscript Type: & Special Issue \\
\hline Keywords: & $\begin{array}{l}\text { Information and Market Efficiency; Event Studies < General Financial } \\
\text { Markets, behavioural finance, value investing, valuation, information } \\
\text { uncertainty, liquidity }\end{array}$ \\
\hline
\end{tabular}

\section{SCHOLARONE Manuscripts}


Abstract:

This paper examines two potential key drivers of the Financial Strength (F-Score) investment strategy: Information uncertainty and liquidity. We use novel, direct measures of information uncertainty related to the variability of Financial Strength signals themselves. However, Financial Strength strategy returns are not generally strongly related to these information uncertainty proxies. We also examine two proxies for liquidity. Financial strength strategy returns are generally substantially larger for illiquid firms. A zero-cost arbitrage strategy based on F-Score generates a $20 \%$ return in illiquid UK stocks and $12 \%$ in liquid UK stocks. The enhanced F-Score effect is driven by a flight from illiquidity amongst financially weak stocks. Overall, the profitability of the F-Score investment strategy appears more closely related to liquidity than to information uncertainty.

\section{Introduction}

The seminal work of Piotroski (2000) demonstrates that financially strong companies outperform financially weak companies by a very large margin. Practitioners have implemented this strategy. Given that financial strength indicators were available prior to the return evaluation period this result is an anomaly according to the efficient market hypothesis. Such anomalies tend to be more prevalent in small firms (see e.g. Fama and French, 2008) but the source of the profits from exploiting anomalies is disputed. Two of the most prominent explanations are that anomalies are due to either information uncertainty (Zhang, 2006) or (il)liquidity (Sadka, 2006; Chordia et al., 2009). We extend this literature by examining whether information uncertainty or illiquidity or both exacerbate the financial strength anomaly in the UK. We use novel, direct measures of information uncertainty estimated from F-Score components themselves; however, the financial strength anomaly is not strongly related to these. In contrast, we find more evidence that illiquidity exacerbates the financial strength anomaly and that there is a flight from illiquid financially weak stocks.

Value investing using financial statement ratios is particularly concerned with the question of whether specific investing strategies can outperform the market on a consistent basis and whether 
they can be implemented economically. Ou and Penman (1989) were among the first to examine thoroughly the predictive power of a set of 68 individual accounting ratios regarding subsequent earnings between 1965 and 1985. In general, early studies were concerned with the uncovering of those ratios with the highest predictive power and therefore criticised by the academic community for their "kitchen sink" approach (e.g. Lev and Thiagarajan, 1993 and Abarbanell and Bushee, 1997). To counter these deficiencies, simpler fundamentals-based investment strategies have been developed and tested more recently. Piotroski (2000) showed that a composite measure of nine accounting ratios applied to high book-to-market (BM hereafter) or value stocks could generate an annual return of more than $20 \%$ in a long-short equity portfolio between 1976 and 1996 . This paper has garnered interest on the part of academics and practitioners because it could be implemented without the need for huge data sets and because it required no holdout period. However, newer research by Duong et al. (2014) suggests that a separation of investment strategies that either focus on value, i.e. high BM firms or glamour, i.e. low BM firms, is unnecessary. The F-Score provided similar results when applied to the entire stock universe as compared to their intended, more limited use. $^{1}$

This paper shifts the focus to the potential causes of the success of the F-Score investment strategies. In other words, it is particularly concerned with the question of what the key drivers of the F-Score-based investment strategy are. Thus, it first explores if firm size is relevant to the success of the original F-Score approach. This question is of interest because various anomalies are concentrated particularly in small firms (e.g. Fama and French, 2008; Fama and French, 2012). For instance, striking anomalies such as the value premium, return momentum and post-earnings announcement drift are usually higher for smaller companies.

Previous work also suggests that anomalies are linked to information uncertainty (IU

\footnotetext{
${ }^{1}$ Mohanram (2005), extended the F-score idea to generate a composite score to generate a G-score that provided a composite measure of the financial condition of low-BM firms by summarising eight accounting signals. The G-Score could generate a $20 \%$ annual return in a long-short portfolio for the period between 1978 and 2001. Duong et al. (2014) also demonstrated that the G-score generated returns when applied to all stocks rather than just low BM firms; however, the magnitude of the returns are generally smaller than the F-score. Consequently this paper focuses only on the Piotroski measures.
} 
hereafter) and liquidity risk. However, this has not been extensively previously examined in the case of the F-Score strategy first introduced by Piotroski (2000). This is surprising given the magnitude of F-Score profits. As firm size proxies for either IU or liquidity, the paper evaluates how dedicated measures of IU and liquidity are correlated with the original strategy. In a related study by Zhang (2006), a set of IU proxies are used. However, the measures of IU used by Zhang (2006) are indirect (e.g. firm size, analyst coverage). For this reason, two novel volatility measures that are directly derived from the F-Score signals themselves are used in this paper. These are based on the standard deviation of the strength of the F-Score signals and the mean absolute deviation of the F-Score signals. Consequently, they measure the variability in the information used to implement the F-Score strategy itself.

The paper advances knowledge in three ways. Firstly, the success of the F-Score investment strategy is most closely related to liquidity and thus can partly explains its success. The annualised return of the F-Score strategy is much higher amongst illiquid stocks (20\%) compared to liquid stocks (12\%). Secondly, market participants favour, ceteris paribus, more liquid stocks and these stocks generate higher rather than lower ex-post returns than illiquid stocks, especially amongst financially weak companies; this flight from illiquid financially weak firms is an important source of the higher F-Score strategy returns amongst illiquid stocks. Thirdly, using novel, direct measures of information uncertainty, we find that generally the profitability of the F-Score strategy is not strongly related to information uncertainty, however, low uncertainty stocks generally generate higher ex-post returns than high uncertainty stocks; this is consistent with market participants generally preferring to invest in companies with low uncertainty.

\section{Background and hypothesis development}

The initial analysis of this paper is on the interplay between a firm's financial strength indicators (Piotroski, 2000) and its size (Fama and French, 2008) to examine how this impacts stock returns. Fama and French (2008) highlight that many stock market anomalies are concentrated in smaller 
firms, however, they do not provide compelling evidence for why this is.

Firm size can capture IU (Zhang, 2006) or firm liquidity (Amihud, 2002). The reasons it could capture IU are less diversification and less information availability due to fewer stakeholders and fewer disclosure requirements by the stock exchange for smaller firms. ${ }^{2}$ However, firm size can only be an approximation of IU (Zhang, 2006), because it might also capture other things, such as liquidity. Illiquid stocks tend to have lower volumes traded which translates into larger trading costs; for example, wider bid-ask spreads, more difficulty in executing large trades without incurring a price impact and also higher information costs.

The response to new information in smaller companies is anticipated to be slower and more gradual than larger companies. From an IU perspective, the greater the volatility of signals about fundamental value the slower investors will be to incorporate this into the firm price. From a liquidity perspective, the greater trading costs and possible price impact of large trades are frictions which limit the speed at which the market responds to a given signal about fundamental value. Our first hypothesis is therefore as follows.

Hypothesis H.1: Smaller (larger) firms, proxied by firm size, provide lower (higher) subsequent returns following bad news and higher (lower) returns following good news.

The main implication of H.1 is that the financial strength strategy should generate larger profits when implemented on smaller firms than on larger firms. It further suggests that for portfolios of low (high) financial strength there should be lower (higher) returns for small firms than large ones.

Zhang (2006) is amongst the first to apply the concept of IU to examine stock market anomalies; his key hypothesis is that IU, slows investor reaction to information and this delayed reaction enables greater profits to accrue to firms with high IU. In his study, the first (horizontal) subdivision into quintiles was based on past average monthly portfolio returns that proxy for

\footnotetext{
${ }^{2}$ Generally, information on large firms is available both at lower costs and more publicly (Bhattacharya, 2001). As most investors have predefined information acquisition costs, some smaller firms are unattractive to them as investment targets.
} 
momentum (or earnings surprises that link to post-earnings announcement drift). The second (vertical) subdivision is according to quintiles of one of the six IU proxies, of which firm size is just one. In general, smaller firms with supposedly greater IU provide better (worse) returns following good (bad) news. By definition, therefore, large (small) firms should feature lower (higher) IU, because, for instance, larger firms are required to meet higher disclosure standards and thus leave less room for interpretation. As defined by Zhang (2006), IU is a function of a firm's fundamental value and a noise term. Therefore, the variation of the IU signal is, in turn, a function of the volatility (v) of the fundamental value and the volatility of the noise term (e). More formally:

and

$$
I U=v+e
$$

Zhang (2006) did not distinguish between $v$ and $e$ and justified this choice by stating that both terms contribute to the measure of IU and separating the two variables is problematic as they are intertwined. Applied to firm size, therefore, smaller firms are characterised by lower information quality which results in more noise (e). If firm size is equated with market capitalisation then market capitalisation is representative of fundamental value $(v)$. However, this argument is only valid on the assumption that markets are efficient under the efficient market hypothesis (EMH). The underlying idea of both equations is shared in the present research and therefore the further analysis is based on Zhang's (2006) approach.

As noted by Zhang (2006), firm size (and the other variables he implements) can be regarded as an indirect measure of IU because it captures other things in addition to IU, which could distort the findings. A more direct indicator would alleviate this potential drawback. In this paper, we use a new direct IU proxy based on the variability of F-Score components. The underlying rationale behind both the standard deviation (SDF) and the mean absolute deviation (MADF) of the F-Score is that greater volatility of the signals is associated with a higher degree of IU. There are two main advantages of using the SDF or MADF as a proxy for IU compared with firm size. Firstly, as noted earlier, these indicators are more direct measures which are not influenced by local market 
conditions. For instance, differing disclosure requirements set by the respective exchange supervisory authority may be a source of IU. Apart from that, firm size is likely to be a noisy measure that captures other things as well (Zhang, 2006).

Secondly, the SDF/MADF measures capture the variability of nine different accounting metrics and should therefore give a very good representation of the disparity amongst the individual indicators of the financial health of a company. If the disclosure requirements apply equally to all firms, as mentioned before, a viable means to measure the level of IU is the volatility of key accounting ratios. The idea is that firms with higher volatility of the F-Score, i.e. higher IU, should generate lower subsequent stock returns and should be slower to respond to information. This follows on from research by Dichev and Tang (2009) for the US and Clubb and Wu (2014) for the UK. Both studies found a negative correlation between earnings volatility and earnings predictability. Thus, for firms with high earnings volatility the valuation effects of new information are more difficult to determine and hence there can be a delayed reaction for firms in such high information uncertainty environments. Thus, the second hypothesis is stated in the following way. Hypothesis H.2: Firms with higher (lower) information uncertainty, proxied by the volatility of accounting fundamentals, provide lower (higher) subsequent returns following bad news and higher (lower) returns following good news.

The main implication of H.2 is that the financial strength strategy should generate larger profits when implemented on high uncertainty firms than on low firms. It further suggests that for portfolios of low (high) financial strength there should be lower (higher) returns for high uncertainty firms than low uncertainty ones.

The presence of liquidity allows investors to trade large quantities in a timely manner, at low costs and with little impact on an asset's price (Liu, 2006). In a seminal paper, Amihud and Mendelsohn (1986) were amongst the first to analyse the effect of liquidity on stock returns. In their model, which represents a market consisting of rational investors with differing investment horizons 
and different asset spreads, they found a positive correlation between the average returns and the bid-ask spread in the cross-section. The wide asset spreads lead to greater trading costs would limit the speed at which the market responds to a given signal about a stock's fundamental value. For example, Bali et al. (2014) report that illiquidity inhibits prices discovery. Furthermore, some investors are discouraged by low-priced stocks and therefore illiquid stocks (Falkenstein, 1996 and Kumar, 2009) which would also slow the adjustment process given that a smaller proportion of investors are willing to trade such stocks. ${ }^{3}$

However, it is also that the case that investors will wish to move to quality investments. Investors would prefer holding portfolios of financially healthy companies, i.e. those with high FScores (and will rebalance their holdings from financially weak companies to financially healthier companies once the signals are received) ${ }^{4}$ Thus, the price of financially weak firms would be driven down and the price of financially strong firms increase consistent with the original F-Score strategy findings of Piotroski (2000). The price impact of such trades will be larger amongst low liquidity firms; hence this will lead to greater profits for those who immediately sell financially weak firms and buy financially strong firms. The aim of the first part of the next hypothesis is to analyse whether liquidity is a determinant of the success of the F-Score strategy.

Hypothesis H.3a: Portfolios of firms with lower liquidity have larger F-Score investment strategy returns.

As noted previously, Amihud and Mendelsohn (1986) report that illiquid stocks earn higher return on average, thus they receive a risk premium for the larger bid-ask spreads and the greater difficulty in making large trades without impacting price. This would suggest that portfolios of less liquid stocks should in general earn higher returns than portfolios of highly liquid stocks, ceteris

\footnotetext{
3 This is consistent with Choi and Sias (2012) who suggest that the financial strength anomaly is weaker in low turnover stocks, which they interpret as linked to investor type; however, they do not explicitly test whether it is liquidity or investor type per se which drives their results.

${ }^{4}$ Investors prefer to trade stocks with some firm-specific stock characteristics such as size, liquidity, earnings per share (Duxbury et al., 2013; Kumar, 2009; Ng and $\mathrm{Wu}, 2006$ ); this should extend to a preference for trading financially healthy stocks.
} 
paribus. This is also supported by using the turnover rate (ToR), as an alternative liquidity proxy by Datar et al. (1998). Silber (1992) provided evidence of a liquidity premium by examining restricted stocks with two-year lock-in periods which trade at a 30 percent discount to regular shares, implying dramatic return premium. More recently, further supportive evidence was presented by Amihud (2002), Hasbrouck (2009) and Asparouhova et al. (2010).

However, other research suggests that illiquidity is not always associated with higher expost returns. Two examples are Brennan and Subrahmanyam (1996), who showed that higher spreads lead to lower returns, and Spiegel and Wang (2005), who found no correlation whatsoever. There are at least three reasons why this may be the case. Firstly, there could be an exogenous shock to the firm's liquidity which in the case of a decrease in liquidity leads to a low return contemporaneously as the stock price adjusts to higher expected returns in future periods; as reported by Bali et al. (2014) responses to liquidity shocks may not be immediate. Secondly, high bid-ask spreads incentivise firms to increase liquidity to reduce their cost of capital, this triggers the same adjustment mechanism as the previous case but in reverse; here the increase in liquidity leads to a high return contemporaneously but to low expected returns in future periods. These first two reasons could mask the general relationship observed in general between liquidity and ex-post returns.

Thirdly, there could be a move to liquidity when bad news (or a weak signal) is apparent. For illiquid stocks when bad news (or a weak signal) is apparent such stocks are sold off while the opportunity is still and the investment transferred to more liquid assets; the reason is there is an increased risk for such stocks that they will become much less liquid and subject to great price impact of any sale or may even become essentially non-tradable. This would lead to (very) low returns for illiquid stocks which receive bad news, which would be driven down further than liquid stocks that receive bad news. Such an effect is supported by Longstaff (2009) and Naes et al. (2011). Longstaff (2009) suggests that after relaxing the assumptions of tradability and liquidity for all assets, investors tend to abandon the optimal diversified market portfolio in favour of highly 
polarised positions, i.e. liquid portfolios once assets become illiquid. Naes et al. (2011) report that there is a related move to liquidity during bad (economic) times where traders move from less liquid stocks to more liquid stocks. ${ }^{5}$ Based on the preceding discussion, the second part of the hypothesis is stated as follows:

Hypothesis H.3b: Following a negative signal firms with lower liquidity generate lower subsequent returns than firms with higher liquidity.

\section{Data}

The main data source is Thomson-Reuters Datastream. To be included in the analysis for a given year, firms need to: i) have a stock market listing in the UK, ii) be non-financial firms, iii) have British pounds (GBP) as their financial reporting currency, iv) have data available for all nine Financial Strength components (used in Piotroski; 2000) from the WorldScope Accounting database (accessed via Datastream), v) not have erroneous or unavailable data. Defunct companies are included in order to avoid survivorship bias. The final data set consists of 3,089 firms for the FScore calculation ${ }^{6}$ using accounting data over 1992-2010. To ensure that all the accounting information from the previous financial year is publicly available returns are calculated from $30^{\text {th }}$ June in each year following the accounting data being reported. One-year buy-and-hold returns (BHR) are calculated. So, for the accounting data reported in 1992, the first year of the study, we calculate the one-year BHR from purchase on $30^{\text {th }}$ June 1993 and held until $30^{\text {th }}$ June 1994; similarly, for the final year of accounting data in 2010, we calculate the one-year BHR from the end of June 2011 to the end of June 2012.

The firms' individual buy-and-hold abnormal return (BHAR) equals the difference between the annual stock return and the equally weighted market benchmark return. It should be noted that the benchmark index is equally weighted rather than value weighted. This method is in line with

\footnotetext{
${ }^{5}$ Investors tend to prefer to hold and trade liquid stocks in general (Duxbury et al., 2013; Kumar, 2009; $\mathrm{Ng}$ and $\mathrm{Wu}, 2006)$, however this preference will plausibly be strengthened during bad times.

${ }^{6}$ In total, 1,392 firms were excluded from the analysis.
} 
Barber and Lyon (1997), who advocated the calculation of simple buy-and-hold returns on a sample firm less the simple buy-and-hold return on a reference portfolio or benchmark index, respectively. ${ }^{7}$

\section{Methodology}

Portfolios are constructed each year and firms are assigned to one of the five portfolios outlined below depending on their Financial Strength. The first measure implemented is Piotroski's F-Score, which is based on nine financial statement items that provide insight into three sections of the company's financial condition (see Appendix A for full information), which are i) Profitability, ii) Leverage, liquidity and source of funds and iii) Operating efficiency. ${ }^{8}$ The F-Score is the sum of each of the nine item's binary signal (zero or one). ${ }^{9}$

The stocks with the highest (lowest) F-Score of 9 (0) are deemed to feature the highest (lowest) levels of financial strength and thus the highest (lowest) probability of generating abnormal oneyear returns. The cut-off points of the portfolios are derived from the distribution of firm years of the F-Score and are constant over time for consistency. ${ }^{10}$ Table 1 presents descriptive statistics relating to the F-Score. Panel A of Table 1 indicates, according to the cumulative percentages, that the F-Scores appear to be relatively evenly distributed, with the lowest and highest portfolios $\left(\mathrm{L}^{*}\right.$ and $\mathrm{H}^{*}$ ) representing about $5 \%$ of the data. More precisely, the lowest portfolio, $\mathrm{L}^{*}$, contains approximately the lowest $5 \%$ of F-Score stocks, ranging from 0 to 2 . This lowest portfolio, in turn, is contained in the low (L) quintile which therefore ranges from 0 to 3 and contains approximately

\footnotetext{
${ }^{7}$ As the authors showed, the calculation of long-run abnormal returns can be subject to problems. However, this is mostly the case in studies in which either daily or monthly abnormal returns are summed with the result of a firm-specific one-year cumulative abnormal return (CAR). Problems can be caused, for instance, due to a rebalancing bias. In this case, the firm's individual CAR would be computed without rebalancing, whereas the reference portfolio would be subject to monthly rebalancing. The same applies if firms are newly listed and included in the reference portfolio. Since the reference portfolio is readjusted only once a year on exactly the same date as the stock returns are measured, these problems are mitigated in the present analysis.

${ }^{8}$ The profitability indicators are: i) return on assets, ii) cashflow from operations, iii) change in return on assets and iv) accruals. The leverage, liquidity and source of funds indicators are: i) change in leverage, ii) change in liquidity and iii) seasoned equity offering. The operating efficiency indicators are: i) change in gross profit margin and ii) change in asset turnover ratio.

${ }^{9} \mathrm{~F}-\mathrm{Score}=\mathrm{FI}_{\mathrm{ROA}}+\mathrm{FI}_{\mathrm{CFO}}+\mathrm{FI}_{\triangle \mathrm{ROA}}+\mathrm{FI}_{\mathrm{ACCRUAL}}+\mathrm{FI}_{\triangle \mathrm{LEVER}}+\mathrm{FI}_{\triangle \mathrm{LIQUID}}+\mathrm{FI}_{\mathrm{EQ} \_\mathrm{OFF}}+\mathrm{FI}_{\triangle \mathrm{MARGIN}}+\mathrm{FI}_{\Delta \mathrm{TURN}}$, where $\mathrm{FI}$ is a binary financial strength indicator and the individual indicators are defined in Appendix A.

${ }^{10}$ Firm years are defined as the cumulative number of firms that provide a full set of relevant data, which is needed for the F-Score calculation for the period 1992 to 2010.
} 
$20 \%$ of the observations. Stocks with an F-Score between 4 and 6 are assigned to the middle portfolio, defined as M. The high portfolio (H), with F-Scores of 7 to 9, encompasses the highest $\left(\mathrm{H}^{*}\right)$ scoring $5 \%$ of the data with F-Scores of 8 and 9, respectively. Therefore, the cumulative distribution is such that approximately $\mathrm{L}=20 \%, \mathrm{M}=60 \%$ and $\mathrm{H}=20 \%$ of all firm years and $\mathrm{L}^{*}$ $\left(\mathrm{H}^{*}\right)$ are included in the $\mathrm{L}(\mathrm{H})$ portfolio.

[Insert Table 1 around here:]

Table 1 panel B reports the number of observations in each F-Score portfolio by year. In every year since the 1995 accounting year there are more than 1000 sample observations per year and these are suitably split between the individual portfolios; even amongst the $\mathrm{L}^{*}$ and $\mathrm{H}^{*}$ portfolios there are almost always at least 40 firms per year. However for 1992 and 1993 especially there are very few observations with a much larger number of 620 observations for 1994. Table 1 panel C reports the information on the distribution of the one-year buy and hold abnormal returns for each portfolio. The top section compares our UK sample (1992-2010 accounting data) with Piotroski's (2000) US sample (1976-1996 data); broadly the distributions are comparable the main difference is in the estimated mean which is substantially positive in Piotroski's US sample due to his use of the value-weighted market index to adjust returns during a period when there was a substantial size premium while we use an equally-weighted index of all sample firms to adjust returns. The second section reports F-score portfolio distributions; these generally decrease monotonically as you go from the highest financial strength $\left(\mathrm{H}^{*}\right)$ to the lowest financial strength $\left(\mathrm{L}^{*}\right)$. Interestingly there is a large difference in the mean between the high financial strength group of $5.4 \%$ and the low financial strength group of $-10.4 \%$ suggesting that investing long in high financial strength companies and short in low financial strength companies would be highly profitable in the UK as Piotroski reported amongst high BM firms in the US. At an individual stock level only $51.5 \%$ of high financial strength companies generate a positive annual buy and hold return; however, only $34.7 \%$ of low financial strength companies generate a positive return. Interestingly the standard deviation of returns is smaller for high financial strength companies compared to weak ones. 
A possible drawback of the F-score method is that it is based on binary signals that are either 0 or 1 . Consequently, it is plausible that this ignores important information specifically that contained by the magnitude of each signal. Hence in this paper we consider an approach based on the rank of firms which is based on the magnitude of each financial strength signal. This approach also enables direct measures of IU based on the variability in the magnitude of the financial strength signals to be calculated. Thus, we implement a ranking and standardisation process for each of the nine F-Score components which is essential to ensure commensurability between them. We use equation (3) to compute the F-rank, which is simply an average of the ranks of the $\mathrm{K}=9$ financial strength indicators, which is standardised by the total number of observations in each year (F-rank); thus the F-rank is a continuous measures of the financial strength estimated of each firm in each year which varies between 0 and 1 . In general, ties between different firms and the same Financial Strength rank component are retained. The F-rank represents the aggregate of the nine Fk-ranks.

$$
F-\operatorname{rank}=\sum_{k=1}^{K} \frac{\left(F_{k, \text { rank }}-1\right)}{\left(F_{\max }-1\right)}
$$

To avoid bias towards a specific method, both the mean and the median of the nine Fi-ranks is taken to construct the standardised F-rank. ${ }^{11}$ Although the utilisation of ranks already ensures the moderation of outlier influence, this approach is another step in this direction compared with a simple addition of values. In comparison with the F-Score, with its binary values, F-rank portfolios require flexible cut-off points that are recalculated on an annual basis. The percentage distributions summarised in table 1 are used as a guideline. Hence, the F-rank cut-off points are set exactly at 5\% for the lowest $\left(\mathrm{L}^{*}\right)$ and highest $\left(\mathrm{H}^{*}\right)$ portfolios, with the remaining portfolios being cut off at $20 \%$ (L), $60 \%(\mathrm{M})$ and $20 \%(\mathrm{H})$.

The BHAR in each of the F-Score portfolios and size/IU/liquidity terciles (one-thirds) is also equally weighted, similar to Zhang (2007) and Dechow et al. (2008). Due to an uneven

\footnotetext{
11 The mean and the median of the $\mathrm{F}_{\text {rank }}$ provided qualitatively similar results and hence just the results based on the mean are reported in the paper.
} 
distribution of F-score firm years as presented in table 1, the portfolios, do not contain the same number of firms except for $\mathrm{H}^{*} / \mathrm{L}^{*}$ and $\mathrm{H} / \mathrm{L}$ portfolios. The portfolios are equally weighted to achieve consistency with the equally weighted BHAR described above, similarly to Hirshleifer et al. (2004). This approach differs from Piotroski (2000) because, originally, portfolios were equally weighted and BHARs were value weighted. There is a debate over the best way to construct portfolios. However, three points justify the use of equal weighting in the present analysis. Firstly, since this paper builds on the original F-Score strategy of Piotroski (2000), it appears useful to follow the original method to ensure comparability. Secondly, Baker and Wurgler (2006) formed equally weighted decile portfolios while researching the relationship of investor sentiment and stock returns in the cross-section. They argued that value weighting is likely to distort the relevant patterns because larger firms are generally less influenced by investor sentiment. Likewise, an underlying assumption of the paper is that stock markets are not efficient at all times but rather subject to nonrational behaviour. Therefore, it is preferable to isolate behavioural biases to examine those using respective measures, such as IU or liquidity. Thirdly and lastly, Benartzi and Thaler (2001) found that most investors use a diversification heuristic when faced with the task of asset allocation. This so-called $1 / \mathrm{n}$ rule is commonly applied in pension plans, in which contributors spread their funds evenly across asset classes (Huberman and Jiang, 2006).

To test for statistical significance and robustness, both the mean and the median returns are calculated and compared for the financial strength zero-investment strategies across the high minus low (H-L) and highest minus lowest $\mathrm{H}^{*}-\mathrm{L}^{*}$ cuts. Portfolio $\mathrm{M}$ is not considered in the further course of the return analysis. The statistical tests implemented are generally well-known and conform to the methods used in the seminal work by Piotroski (2000) on the F-Score. ${ }^{12}$ When examining size,

${ }^{12}$ In general, unpaired two-sample t-tests are conducted to test the equality of means of the percentage stock returns between portfolios with high/low and highest/lowest financial strength portfolios. The same tests are then applied holding financial strength constant across terciles (thirds), which represent the second dimension, i.e. size, IU and liquidity. As noted by Kothari and Warner (1997), long-horizon parametric test results might suggest abnormal performance when none actually exists (due to model misspecification); hence they recommend the use of non-parametric tests. Consequently, the non-parametric version of the ttest, which was originally introduced by Wilcoxon (1945) and modified by Mann and Whitney (1947), is applied in this paper. According to Neave and Worthington (1988), the Mann-Whitney-Wilcoxon (MWW) 
information uncertainty and liquidity we sort firms on each indicator independently to financial strength into three groups with dividing points at the $33.3 \%$ and $66.6 \%$ percentile. So, for example the small firm portfolio contains the $33.3 \%$ of firms with the lowest market capitalization, while the large firm portfolio contains the $33.3 \%$ of firms with the highest market capitalization.

We implement two information uncertainty measures. To construct the first information uncertainty measure (IU), we utilise the standard deviation of F-ranks and estimate the overall dispersion of the financial strength indicators (the F-ranks). Thus, it should give an excellent indication of information uncertainty surrounding the firm's financial strength. The higher (lower) the standard deviation of the financial strength ranks, the higher (lower) the information uncertainty. The SDF which is defined as the standard deviation of the F-rank of each firm and year is computed by using the following equation.

$$
S D F_{i, t}=\sqrt{\frac{\sum\left(F-\operatorname{rank}_{i, t}-\overline{F-\operatorname{rank}_{t}}\right)^{2}}{(n-1)}}
$$

The second IU measure is based on the mean absolute deviation of the F-rank. It represents an alternative measure to the SDF and thus can be regarded as an overall robustness check of the previous SDF results. It is computed as follows.

$$
M A D F_{i, t}=\frac{\sum\left|F-\operatorname{rank}_{i, t}-\overline{F-\operatorname{rank}_{t}}\right|}{n}
$$

For both IU measures we sort firms on the basis of the scores (independently) with the lowest-third being placed in the IU1 (Low) portfolio and the highest-third being placed in the IU3 (High) portfolio.

We also examine two measures of liquidity. With regard to our first liquidity indicator, we construct the Amihud measures as follows:

$$
I L L I Q_{i, t}=1 / D_{i, t} \sum_{\mathrm{t}}^{\mathrm{D}_{\mathrm{i}, \mathrm{t}}}\left|\mathrm{R}_{\mathrm{i}, \mathrm{t}, \mathrm{d}}\right| / \mathrm{VOL}_{\mathrm{i}, \mathrm{t}, \mathrm{d}}
$$

test is widely used and virtually as powerful as its parametric counterpart. Finally, Mood's (1950) median test for two independent samples is applied as a robustness check. 
For each firm and each year, ILLIQ is the result of the absolute daily stock return in one year divided by its respective volatility expressed in British pounds. In this context, $D_{i, t}$ represents the number of days in one specific year for each firm. As a result, lower values of ILLIQ are associated with more liquidity and vice versa.

The turnover ratio (ToR) captures the trading quantity dimension rather than the price impact dimension and is computed as follows.

$$
T o R_{i, t}=1 / D_{i, t} \sum_{\mathrm{t}}^{\mathrm{D}_{\mathrm{i}, \mathrm{t}}} \mathrm{VOL}_{\mathrm{i}, \mathrm{t}, \mathrm{d}} / \mathrm{NOSH}_{\mathrm{i}, \mathrm{t}, \mathrm{d}}
$$

The equation states that the ToR for the individual firm $i$ in year $t$ equals the daily trading volume of its stock scaled by the number of shares outstanding on this day. Because either no trading takes place or no data are available for several days, the previous result is divided by the amount of days for which data are available. It serves as a robustness check for the Amihud measure.

For both liquidity (LQ) measures we sort firms on the basis of the scores (independently) with the most illiquid being placed in the LQ1 (Low) portfolio and the highest-third being placed in the IU3 (High) portfolio. Please note that for the Amihud measure that high scores correspond to illiquidity and thus the highest third on the Amihud measure are placed into the LQ1 portfolio, while for ToR the third with the lowest scores are assigned to LQ1.

[Insert Table 2 around here:]

Table 2 provides portfolio descriptive statistics. Panel A begins by providing for each F-Score portfolio, the average rank for size and for each information uncertainty and liquidity variable; we focus on the F-score since F-rank portfolio descriptive statistics are broadly similar and are available upon request. The average rank for each portfolio is generally close to 0.5 and the standard deviations indicate there is substantial variation in all cases. Table 2 panel $\mathrm{B}$ gives an overview of the average number of stocks in each of the two-way sorted portfolios, which are sorted on a) financial strength: either F-Score or F-rank and b) on size or IU or LQ. The 
average number of stocks per year over 1994-2010 (accounting years) in each portfolio is generally between $40-80$ per year which in terms of total observations equates to $680-1360$. There are some slight patterns apparent; for example there are slightly fewer i) small firms displaying either high or low financial strength, ii) high financial strength high uncertainty firms and iii) amihud low liquidity firms displaying either high or low financial strength. However, in terms of the total number of observations there are still more than sufficient observations for inference to drawn in the subsequent analysis.

Table 2 panel C provides information on migration for the F-Score portfolios of interest. What is very clear is that each year there is substantial turnover across the portfolios. At most $26 \%$ of firms by number and $30 \%$ of firms by market value remain in the same portfolio (Small - High F-Score); in many cases it is substantially less than this. Further, up to $20 \%$ of firms are dissolved or do not have sufficient data for an F-Score to be calculated the following year, which means that every year more than $60 \%$ of firms move to a different portfolio. Most of these changes are due to changes in the F-Score, perhaps unsurprisingly firms find in difficult to continually increase profitability, increase operating efficiency and decrease leverage (or vice-versa). However, if someone were to implement the F-Score strategy given that we are considering annual buy and hold returns, even given there is substantial turnover, this would only occur once a year which would ameliorate the level of transaction costs incurred compared to strategies with monthly, weekly or even daily rebalancing.

\section{Empirical Results}

\subsection{Firm size}

The first step in answering questions about the driving forces behind the F-Score strategy is to analyse the relationship between F-Score return portfolios and company size terciles. Table 2 documents the respective findings where portfolios were independently sorted by their F-Score and also by size, such that the order of sorting is irrelevant. The same structure is kept throughout the 
paper where panels A.1 and B.1 report the winsorised mean and panels A.2 and B.2 the winsorised median portfolio returns. In this sub-section we provide evidence relating to Hypothesis 1, specifically, whether i) the financial strength strategy is more profitable amongst small firms; horizontal dimension of Table 2 and ii) whether smaller firms generate lower (higher) returns following a weak (strong) financial strength signal; vertical dimension of Table 2.

Beginning with panel A.1, the horizontal findings show that the F-Score strategy is particularly fruitful for smaller-sized (S) companies and that those results are highly significant consistent with H.1. For instance, a long-only strategy based on the highest F-Score portfolio and the smallest firm size group (bottom third by size) thereby yields an annual return of $10.4 \%\left(\mathrm{H}^{*}, \mathrm{~S}\right)$. With the additional option to short the lowest F-Score portfolio in the same size tercile, the horizontal mean return difference extends to 23.6 percentage points $\left(\mathrm{H}^{*}-\mathrm{L}^{*}, \mathrm{~S}\right)$. The analysis of the median portfolio returns and return differences in panel A. 2 reveals a very similar trend, with highly significant median test results. This magnitude of the F-Score strategy returns amongst small firms is not close to being matched by the larger (B) firms.

With regards to the alternative F-rank method panels B.1 and B.2, the findings confirm the benefits of the original F-Score strategy are enhanced when implemented on companies with small market capitalisation. Overall, though, both the portfolio returns and the financial strength strategy returns (HL and $\left.\mathrm{H}^{*}-\mathrm{L}^{*}\right)$ are less pronounced than with the F-Score method. Although all the tstatistics of the small firms' portfolios are significant at the $1 \%$ level, the return differences between the $\mathrm{H}^{*} / \mathrm{L}^{*}$ portfolio within the large-firm tercile turn out to be only marginally significant at the $10 \%$ (panel B.1) level. The evaluation of the corresponding median portfolio returns in panel B.2 provides a very similar picture again. However, the F-rank method underperforms the F-Score strategy in absolute percentage terms throughout.

[Insert Table 3 around here:]

An interesting part is the analysis of the vertical return differences between portfolios consisting of the largest and smallest firms (B-S or big minus small) as it provides answers to the 
second implication of the first hypothesis. It aims to determine whether firm size in combination with the F-Score strategy as an indicator of information quality behaves as anticipated by Zhang (2006). If this is the case, small firms should provide better (worse) results following good (bad) news than large firms. The uncertainty of news is thereby determined by the respective size portfolio. In our setting, following the logic of Piotroski (2000), high (low) financial strength is a measure of good (bad) news. Focusing first on the F-Score strategy in panel A.1, this trend is generally confirmed. Small firms in the $\mathrm{L}^{*}$ and $\mathrm{L}$ quintiles are outperformed by their larger competitors, as predicted by Zhang (2006). However, the results of the t-tests are insignificant and suggest that the portfolio returns within the F-Score quintiles are not driven by firm size.

In contrast the non-parametric tests, the MWW results document some significance for all the vertical return differentials except for the $\mathrm{H}^{*} \mathrm{~F}$-Score portfolio. On the one side, small firms in the $\mathrm{L}^{*}$ F-Score portfolio return $-13.2 \%$ over the year, whereas large firms return $-10.1 \%$. The difference of 3.1 percentage points is significant at the $10 \%$ level $(t=1.84)$. This seems to imply that size proxying for IU is positively correlated with one-year returns for companies with the $\mathrm{L}^{*} / \mathrm{L}$ F-Scores, as initially observed by Zhang (2006) for the US stock market. On the other side, the H and $\mathrm{H}^{*} \mathrm{~F}$-Score portfolios within the small-size tercile have higher one-year returns of $7.2 \%$ and $10.4 \%$, respectively. However, although the return difference between the big minus small (B-S) tercile is only significant for the $\mathrm{H}$ but not the $\mathrm{H}^{*} \mathrm{~F}-\mathrm{S}$ core portfolios, the signs are not as expected. In other words, large firms continue to outperform smaller ones based on positive MWW test statistics throughout.

These findings are further supported by the mean portfolio returns in panel B.1. While large firms significantly outperform smaller ones in the Low F-Score quintile, the remaining parametric test results are not significant. All the significant differentials in those two panels feature a positive sign in the case of the non-parametric t-statistics. Consequently, larger firms are more profitable within their respective quintile. In addition, these findings are consistent with the results of the median return portfolios reported in panels A.2 and B.2 and therefore point to the same conclusion. 
As can be seen from there, larger firms consistently outperform their smaller peers, with the majority of the return differences being highly significant. In summary, in relation to the mixed parametric test results, both the MWW and the median test statistics appear to be strong and thus should be regarded as determinative in this case. This suggests that Dimson and Marsh's (1999) reversal of the size effect is apparent also amongst stocks sorted on financial health. However, the vertical t-tests show little evidence of significance.

The UK results of the F-Score method presented in table 2 support Fama and French's (2006b) findings that specifically size is an important determinant for returns. However, this depends on the scenario under scrutiny. In the case of the horizontal return differentials, both the parametric and the non-parametric test results strongly underline the strength of the F-Score as a forecasting tool, which is enhanced amongst small firms. For low financial strength companies then large firms consistently outperform smaller ones, while for high financial strength companies the results are mixed. With this in mind, the results of the original F-Score strategy indicate that the absorption of new information into stock prices is incomplete due to significant horizontal return differentials. Although, this effect is not dependent on a firm's market capitalisation, it is enhanced amongst smaller companies; the evidence that it is still apparent amongst large firms is contrary to Zhang's (2006) US findings for momentum. In summary, H.1 is only partly confirmed as small firms do produce lower returns in the case of bad news but in many cases still do so for good news.

\subsection{Information uncertainty - SDF}

We now examine direct measures of information uncertainty. First we consider the standard deviation of F-ranks; the overall dispersion of the financial strength indicators is estimated as outlined in (4). Stocks are independently assigned to one of three equally sized groups from IU1 (lowest uncertainty) to IU3 (highest uncertainty) according to the magnitude of SDF. These terciles of the SDF are now shown on the vertical axis in Table 4. The structure of Table 4 follows table 2 whereby winsorised F-Score (F-rank) mean portfolio returns in panel A.1 (B.1) and the respective 
median equivalents in panel A.2 (B.2).

[Insert Table 4 around here:]

We initially examine the main implication of hypothesis 2 that the financial strength strategy returns are larger in high uncertainty groups. As can be observed from table 4 panel A.1, the FScore once again is able to separate future winning stocks reliably from losing ones. For instance, the highest F-Score portfolio in the highest SDF tercile returns a positive $10.7 \%\left(\mathrm{H}^{*}, \mathrm{IU} 3\right)$ annually compared with a negative $14.8 \%$ for the lowest portfolio $\left(L^{*}, I U 3\right)$. Hence, the difference between the returns of those portfolios is a huge 25.5 percentage points, with parametric t-statistics of 4.17 . Similarly, the horizontal winsorised median portfolio differentials are highly significant for the investment strategy. For the high SDF tercile, the greatest difference is observable in panel A.2, which amounts to 30.5 percentage points $\left(\mathrm{H}^{*}, \mathrm{IU} 3\right)$. This is further supported by highly significant test statistics for the F-rank portfolios in panels B.1 and B.2. ${ }^{13}$ Finally, there are cases where the financial strength strategy is larger for low uncertainty groups than high uncertainty groups; the $\mathrm{H}^{*}$ $L^{*}$ financial strength strategy returns in panels B.1 and B.2 illustrate this. Consequently, the main implications of hypothesis 2 are not fully supported when the F-rank is considered.

The second part of hypothesis 2 indicates that high (low) uncertainty firms outperform following a high (low) financial strength signal which proxes good (bad) news. This can be examined for the SDF measure of information uncertainty by examining the vertical differences between the IU3 and IU1 portfolio for a given level of financial strength. We report that the winsorised mean portfolio returns are significant for some quintiles under parametric test conditions. In panel A.1 (B.1), the Low Financial strength quintile yields a return differential of $6.5(-6.5)$ percentage points which is highly significant both in terms of the t-statistics and nonparametric test statistics. This indicates that firms with low uncertainty perform better following bad news consistent with the second part of hypothesis 2 . However, the remaining vertical

\footnotetext{
${ }^{13}$ As previously reported for the although the long-short (H-L) differentials are of smaller magnitude compared to the F-Score.
} 
differences are rather mixed especially when varying uncertainty while holding high financial strength fixed. For the $\mathrm{H}^{*}$ F-Score group, the positive signs of the IU3-IU1 differentials suggest better performance of high-uncertainty portfolios consistent with the second part of hypothesis 2 . However, for the $\mathrm{H}$ groups the reverse is the case contrary to what was hypothesised; furthermore some test statistics are significant in the opposite direction to that anticipated. In general, the analysis of the median return panels A.2 and B.2 are broadly consistent with the analysis for mean returns.

\subsection{Information uncertainty - MADF}

Table 5 provides further evidence on hypothesis 2 by providing test results for the second information uncertainty measure, MADF, which is based on the mean absolute deviation of the Financial strength signals. The F-Score and F-rank strategies once again show a strong ability to discriminate between future losing and future winning stocks. This outcome is underlined by highly significant horizontal return differences in all scenarios as a result of both the parametric and the non-parametric tests. In panel A.1 (B.1), for example, the $\mathrm{H}^{*}$ (F-Score)/IU1(MADF) portfolio delivers an absolute return of $6.9 \%(6.6 \%)$ and the respective horizontal difference from the $\mathrm{H}^{*}-\mathrm{L}^{*}$ portfolio amounts to a total of 22.8 (20.2) percentage points, with t-statistics of 7.26 (5.19) highly significant at the $1 \%$ level. Additional evidence for the validity of those results is provided by the median tests. As can be seen in panel A.2, the test statistics are significant at the $1 \%$ level throughout (apart from one exception in panel B.2). In summary, the MADF portfolios closely mirror the results of the two-way SDF portfolios of table 4 in regard of the horizontal return differentials. Hence, both strategies are robust across the two different ways of calculating IU.

[Insert Table 5 around here:]

In view of the second part of H.2, for the vertical differences, the parametric test results are mainly weak. In panel A.1, for instance, the only significant t-statistic of the $\mathrm{H}-\mathrm{L}$ portfolios is located in the L quintile, with a value of -2.24 . Further, the $\mathrm{H}^{*}$ quintile indicates that highuncertainty (low-uncertainty) firms return 16.2\% (6.9\%), in line with Zhang's (2006) findings. 
However, test results for the median winsorised returns in panel A.2 are confirmative of the SDF results i.e. low uncertainty firms generally outperform their high uncertainty peers. The strategy produces significant results for the $\mathrm{H}$ and L quintiles, which is also generally in accordance with the SDF findings. All in all, however, the F-Score strategy provides results that reasonably indicate better performance for the low IU stocks and vice versa. These findings are supported by the F-rank results in panels B.1 and B.2.

\subsection{Summary of information uncertainty measures}

In this paper, both the SDF and MADF of the Financial strength indicators are used as direct proxies for IU and which are directly linked to the Financial strength strategy examined. This is in contrast to Zhang (2006), who analysed six indirect IU proxies with regard to momentum and postearnings announcement drift. ${ }^{14}$ Higher volatility is associated with higher IU but there is a distinction to be made between the types of volatility, which are not further specified by Zhang (2006). On the one hand, cash flow volatility could be interpreted as a direct measure of a certain financial statement item. On the other hand, forecast dispersion could be regarded as the outcome of financial statement interpretation. Consequently, the latter measure is of an indirect nature because the amplitude of the volatility depends on analysts' information processing ability. Because investors apply certain heuristics to reduce the complexity of the information at hand, volatility is highest if there is deep disagreement on the interpretation of information. Both the SDF and the MADF are based on this underlying logic by examining the variability of the signals from the accounting indicators of financial strength and circumvent the problem of information processing. Therefore, it is a simple and effective measure. ${ }^{15}$

The SDF and MADF IU measures do not fully confirm findings using IU proxies for momentum in the US (Zhang, 2006). Zhang (2006) found that the market reaction to newly

\footnotetext{
${ }^{14}$ The six information uncertainty proxies in Zhang (2006) are: firm size, firm age, analyst coverage, forecast dispersion, stock volatility and cash flow volatility.

15 These measures should be as simple and effective as the Apgar score, which is widely used in medicine to evaluate the health of newborns (Finster and Wood, 2005).
} 
published information is incomplete amongst high uncertainty groups; using one-month-ahead stock returns Zhang finds that greater IU generates lower (higher) returns following bad (good) news. However, the analysis has shown that UK investors generally prefer portfolios with low information uncertainty regardless of the news signal consistent with the US study of Jiang et al. (2005). ${ }^{16}$ Consequently, as investors subsequently reallocate their money from the low F-Score and high IU firms to the low-uncertainty stocks with high F-Scores, their returns should be relatively higher one year ahead because the demand for them increases. The relatively better performance of stock portfolios with low uncertainty, implies that market inefficiency is still present to some extent, where stock prices mean revert and former losers become future winners (e.g. De Bondt and Thaler, 1985; Fama and French, 1988; Poterba and Summers, 1988) and prices are almost continuously in disequilibrium (Kothari et al., 2010). Such overshooting may even be fuelled by usually rational investors. As a consequence of rational finance theory, investors would possess the ability to recognise this disequilibrium fully. However, if rational investors thought they could profit from the disequilibrium, they would follow the trend rather than countering it, leading to a larger disequilibrium (O’Hara, 2008).

In summary, the results of the Financial strength strategy under various IU measures shows strong evidence in favour of an incomplete market reaction to newly published information; buying high financial strength companies and selling low financial strength companies generates large and highly significant returns. Results are generally consistent with the first part of hypothesis 2 since generally, if not always, the strategy returns are of greater magnitude for high uncertainty groups (H-L,IU3 > H-L,IU1). However, using the volatility of financial statement items, as measured by the SDF and MADF, indicates investors' preference for portfolios with low IU in the UK stock market especially amongst low financial strength companies which have received bad news. Thus, the second hypothesis 2 is only partly confirmed since there is little evidence that amongst high

\footnotetext{
${ }^{16}$ Jiang et al. (2005) studied the role of IU in forecasting cross-sectional stock returns. They find IU is indeed priced but in the wrong direction, i.e. there is a negative relationship between all IU proxies and future returns.
} 
financial strength firms that high IU stocks outperform.

\subsection{Liquidity - The Amihud measure}

We next examine proxies for liquidity. As Amihud (2002) hypothesised, illiquid stocks should feature higher future returns to compensate for liquidity risk. However, it is of interest whether this is also the case in conjunction with the F-Score strategy where illiquidity could delay the incorporation of information into the share price. Hence, we can test first whether the investment strategy is working reliably irrespective of the level of liquidity in a certain stock. If this requirement is met, then the horizontal portfolio return differentials should be positive, indicating that the higher (lower) the financial strength, the better (worse) the subsequent performance. Then, we can analyse whether the financial strength strategy is enhanced amongst illiquid stocks (hypothesis H.3a).

[Insert Table 6 around here:]

Panels A.1 and B.1 (A.2 and B.2) contain the winsorised mean (median) portfolio returns and the respective parametric and non-parametric test results. The analysis of the horizontal mean return differentials indicates strong support for the ability of the investment strategy to distinguish between future outperformers and underperformers. The highest percentage differences can thereby be found in panel A.1 within the low-liquidity tercile. For instance, the percentage differences between the $\mathrm{H} / \mathrm{L}$ and the $\mathrm{H}^{*} / \mathrm{L}^{*} \mathrm{~F}-\mathrm{Score}$ (F-rank) mean return portfolios amount to 17.1 (13.6) and 22.3 (17.6) points, respectively, which are significant at the $1 \%$ level. Without any exception, all the parametric tests are highly significant. Exactly the same results are observable for the MWW tests while the effect is more pronounced in panel A.1. Overall, therefore, it can be concluded that the strategy performs as expected within the same liquidity tercile.

On the other hand, the logic of an illiquidity premium could be questioned. For instance, stocks that are part of a high $(\mathrm{H}) \mathrm{F}$-Score portfolio have favourable future prospects in terms of stock returns. If this portfolio is now split into two separate sub-portfolios according to the levels of liquidity of their contained stocks, the following question arises: Why should the portfolio with lower liquidity yield higher returns than the one with higher liquidity? If rational investors regard 
both portfolios as equally likely to deliver satisfying yields, they should normally prefer the one with higher liquidity (hypothesis H.3b). In this case, the stock returns should turn out to be relatively higher because of increased investors' demand for more liquid stocks, indicated by the Amihud measure described in equation 6 . Table 6 presents the results of the winsorised percentage portfolio returns, following the same structure as previous tables.

Regarding the vertical return differences, the test statistics are weaker, especially for both of the extreme portfolio quintiles, for which no significance was found. Panel A.1 documents some significance but only for the L quintile differentials. Higher levels of significance are reported in the non-parametric test environment, but this is limited to the $\mathrm{L}$ and $\mathrm{H}$ quintiles only.

Regarding the median portfolios in panel A.2, the test results generally resemble those of the previous portfolios. The horizontal differentials are significant at the $1 \%$ level throughout, while the vertical counterparts are mostly relevant only within the low and high quintiles. This means that high-liquidity portfolios perform relatively better, which is in favour of the liquidity hypothesis.

\subsection{Liquidity - The ToR measure}

This section deals with the turnover ratio (ToR) proxy for liquidity outline in equation 7 , which is an alternative to the Amihud measure. The results of the two-way portfolios with ToR as the second dimension are summarised in table 7.

[Insert Table 7 around here:]

Of interest first are the results of the horizontal differentials, which are linked to H.3a. An analysis of all panels reveals that both the parametric and the non-parametric test outcomes are significant at the $1 \%$ level. This confirms the previous findings of the Amihud two-way portfolios. However, the horizontal differences are more pronounced for the ToR measure. This means that long/short investors, are able to increase the profits of the financial strength strategy in most cases. Thus H.3a is more strongly supported.

The vertical portfolio return differences (between high and low turnover portfolios) are now examined with a focus on the mean returns of panel A.1. It is conspicuous that the L* and L F-Score 
portfolios are highly significant in the test results at the $1 \%$ level. These higher returns occur in the high-liquidity terciles for financially weak firms. Evaluating the non-parametric test results yields a similar picture. For financially strong firms the returns are of similar magnitude amongst both the high and low turnover groups. The vertical return differentials of the winsorised median return portfolios presented in panel A.2 further substantiate these findings, which means that except for the highest portfolios investors prefer stocks with higher liquidity. This trend manifests itself particularly in the $\mathrm{L}$ and $\mathrm{L}^{*}$ groups. For example, the vertical percentage difference within the $\mathrm{L}$ quintile in panel A.1 amounts to 9.7 points, while the $L^{*}$ one is higher with 11.8 points; this is also confirmed by significant test results in panels B.1 and B.2. Thus, it is clear that with ToR, most action is taken by investors who hold low-quality portfolios. Bad news is perceived as a signal that stocks that already underperform are deemed to continue this trend in the future, especially from illiquid stocks with low financial strength the extremely low returns implies a sell-off consistent with H.3b. Regarding both liquidity hypotheses, the results are generally as expected and hence hypotheses H.3a and H.3b are confirmed.

\subsection{Summary of liquidity measures}

It has been proposed that an illiquidity premium can be observed in a theoretical asset pricing setting. However, as outlined in the hypothesis development sections there are reasons why this might not be easily observed in ex-post data. Partly this is because liquidity shocks drive unanticipated returns in the opposite direction to expected returns. Further when there is a bad signal then investors are likely to desert illiquid stocks which cannot be sold cheaply or easily especially in such circumstances (Longstaff, 2009), which may drive down prices of such stocks especially if investors herd (Ivković and Weisbenner, 2007; Ng and Wu, 2010).

The observations in tables 6 and 7 lead to the following conclusions. Firstly, investors with a long-short financial strength strategy generate much larger profits when the implement it using illiquid stocks rather than liquid ones (e.g. H-L LQ1 > H-L LQ3); this clearly supports hypothesis 3a that investing in more illiquid stocks enhances the F-Score strategy. Secondly, the hypothesis of investors' liquidity preference is supported (holding financial strength constant). This is due to the 
consistent outperformance of the high-liquidity terciles as opposed to the low-liquidity terciles, especially for the low financial strength portfolios. In other words, this means that investors are more inclined to sell low-liquidity stocks especially following a negative signal (low financial strength); this is consistent with hypothesis $3 \mathrm{~b}$. What is behind these results? The answer is find by looking at the low (L) financial strength portfolios for liquid minus illiquid stocks (LQ3-LQ1), in which the parametric and the non-parametric t-statistics for are at least significant at the $10 \%$ level. This supports hypothesis $3 \mathrm{~b}$ that there is a flight from illiquidity amongst financially weak stocks and is entirely consistent with investors heavily selling such assets.

In summary, liquidity is a key driver of financial strength investment strategy returns. The most plausible reasons for this are an initial delayed reaction to new information (Hong and Stein, 1999; Bali et al., 2014), which includes a move to quality from firms with weak financial strength to higher financial strength and a move to liquidity from illiquid firms with weak financial strength to more liquid firms (Longstaff, 2009; Karolyi et al., 2012). This process is most likely enhanced by herding behaviour whereby institutional investors begin the transitioning process, which is subsequently followed by the broad market (e.g. Ivković and Weisbenner, 2007; $\mathrm{Ng}$ and $\mathrm{Wu}, 2010$; Choi and Sias, 2012).

\section{Further Empirical Analysis}

\subsection{Robustness tests}

In this section we provide further empirical analysis. This sub-section provides robustness tests on i) the breakpoints used for financial strength classification and ii) adjusted returns via an industry average rather than just a market average.

One of the advantages of the F-rank is that it is more flexible than the F-score, which means examining the effect of changing the point at which a firm is classified as high financial strength (or low) is relatively straightforward. In contrast the F-score which is based on discrete data can only take on integer values between 0 and 9 , which means change the classification point typically involves including or excluding a large proportion of observations. In Table 8 we report results 
where the top and bottom $10 \%\left(\mathrm{H}_{10}\right.$ and $\left.\mathrm{L}_{10}\right)$ and top and bottom $30 \%\left(\mathrm{H}_{30}\right.$ and $\left.\mathrm{L}_{30}\right)$ are used as financial strength classifications. We report results for the mean returns of the F-rank groups. These are broadly consistent with the earlier results. F-rank investment strategies (e.g. $\mathrm{H}_{30}-\mathrm{L}_{30}$ ) are consistently profitable. They are always more profitable amongst the more illiquid firms, especially for the ToR measure. For information uncertainty, the $\mathrm{H}_{30}-\mathrm{L}_{30}$ strategies are more profitable amongst the low uncertainty group (IU1) but performance across IU groups is similar for the $\mathrm{H}_{10^{-}}$ $\mathrm{L}_{10}$ strategy; thus $\mathrm{H}_{30}-\mathrm{L}_{30}$ is more in line with $\mathrm{H}-\mathrm{L}$, while $\mathrm{H}_{10}-\mathrm{L}_{10}$ is closer to $\mathrm{H}^{*}-\mathrm{L}^{*}$.

[Insert Tables 8 and 9 around here:]

For the second robustness exercise we adjust the returns. It is plausible that we are at least partly capturing industry effects in our analysis. To control for this possibility we take the industry average of the market adjusted return for each period and then subtract this from the firm's market adjusted return in that period. We use the ICB level 4 industry calculation, which is based on 41 industries to do this. The results for F-score are reported in Table 9. ${ }^{17}$ The key results are qualitatively similar to those which are previously reported especially the F-Score strategy investment returns. The only notable difference is that the industry-adjustment tends to reduce the financial strength strategy returns by perhaps $1 \%-2 \%$, however it does this consistently across high and low uncertainty groups and also illiquid and liquid groups.

\subsection{Financial strength strategies in the time series.}

The results so far have all been based on pooled observations of one-year buy and hold returns. We now consider the time-series performance of the financial strength strategy (H-L) using accounting data from 1994-2010. ${ }^{18}$ while Figure 1 plots the return data for the F-Score strategy by year. Perhaps the most striking feature of figure 1 is that the H-L strategy return is positive is the overwhelming majority of years. For the F-Score itself panel A of figure 1 it is only negative when implemented using 1998 accounting data which is when the buy and hold return ended in June 2000

\footnotetext{
${ }^{17}$ Results for F-rank were qualitatively similar and are available upon request.

${ }^{18}$ For 1992 and 1993 there were insufficient observations to include them in the analysis.
} 
during the bursting of the dot-com bubble. In fact in none of the graphs is the F-score strategy return negative in more than 4 of the 17 years. Panel B of figure 1 indicates that the F-score strategy is much less variable for the low uncertainty groups and amongst though low uncertainty groups is only negative using the first year of accounting data, 1994. Panel C clearly demonstrates that the Fscore strategy is generally of much greater magnitude amongst the low liquidity groups than the high liquidity groups, consistent with prior results.

[Insert Table 10 and Figure 1 around here:]

Table 10 reports the average, standard deviation and Sharpe ratio of the financial strength strategy over the 17 years of accounting data from 1994-2010. It includes both the F-score and Frank measure of financial strength. As noted in relation to figure 1 the financial strength strategies perform consistently well; the standard deviations are relatively low compared to the average strategy returns. ${ }^{19}$ As such the Sharpe ratios, calculated since this is a zero investment strategy as the average return divided by the standard deviation, are relatively high. The market equity premium, itself considered to be puzzlingly high typically has a Sharpe ratio approaching 0.4 . Here in several cases the financial strength strategy generates a Sharpe ratio above 1 . In terms of hypothesis $3 \mathrm{a}$ we find consistently that the return and Sharpe ratio for the strategy using illiquid firms is higher than for the liquid ones; for ToR the F-score strategy amongst illiquid firms generates a time-series return of $21.7 \%$ and a Sharpe ratio of 1.61 . This provides further support for H.3a. In contrast the results for the main part of H.2 are rather different. For information uncertainty, while we typically find the time series return is slightly larger for high uncertainty firms (IU3) consistent with H.2, the Sharpe ratios are generally substantially higher for the low uncertainty firms; this occurs because the standard deviation of the strategy is much smaller for low uncertainty firms. Consequently, this would suggest that investors may be better advised to implement the financial strength strategy on low uncertainty stocks.

\footnotetext{
${ }^{19}$ Thus despite the small number of time series observations, t-tests would find these returns highly significant.
} 


\subsection{Regression tests}

Finally, we examine the effect of controlling for key known determinants of stock returns, specifically the book-market ratio and the lagged annual return by implementing regression tests. We use the proxies of information uncertainty and liquidity from the earlier section. For the regression tests, we assign each firm its percentage rank for each year for each of these indicators. We also use an average of the two liquidity measures (Av LQ) and the two information uncertainty measures (Av IU). These regressions can also enable us to test if the financial strength strategy returns are enhanced amongst the high information uncertainty (H2a) or illiquid stocks (H3a).

Pooled regressions are used to estimate the impact of IU and LQ on the stock return, with standard errors based on clustering by firm. In Table 11-12 we estimate:

$$
R_{i t+1}=\propto+\beta_{1} F S_{i t}+\beta_{2} X_{i t}+\beta_{3} F S_{i t} X_{i t}+\sum_{j=1}^{J} \gamma_{j} Z_{j i t}+\varepsilon_{i t}
$$

where, the dependent variable is the annual buy and hold abnormal stock return $\left(\mathrm{R}_{\mathrm{it}}\right)$, which is either adjusted for the market return or the market return and the industry return. $F S$, is a financial strength dummy variable which is 1 for high financial strength, 0 for medium financial strength, and -1 for low financial strength. $\mathrm{X}$ is one of the proxies for either liquidity or information uncertainty. $\mathrm{Z}$ contains the control variables especially book-market ratio and the lagged market return ${ }^{20}$ and $\varepsilon_{i t}$ is an error term. The interaction term is the financial strength dummy multiplied by a proxy for information uncertainty or liquidity. $\beta_{1}$ can be interpreted as half the financial strength premium for firms with the lowest level of each $\mathrm{X}$ indicator $(0)$. The interaction coefficient $\left(\beta_{3}\right)$ can be interpreted as half the change in the Financial strength strategy return from moving from the lowest firms (0) on each X indicator to the highest (1). This provides another estimate of the extent of the increase in the financial strength strategy return by investing in high IU or low LQ and also whether this is statistically significant.

Table 11 Panel A presents results for the F-Score financial strength indicator for the full

\footnotetext{
${ }^{20}$ Regressions were estimated that included size as a control variable, but size was statistically insignificant in most cases and hence is not reported. As noted by Dimson and Marsh (1999) the size effect in the UK varies over time and reverses in some periods.
} 
sample. For Model 2, the turnover ratio liquidity proxy this indicates a financial strength premium of $16 \%(2 \times 0.080)$ for firms with the lowest levels of turnover, but this reduces by $6.4 \%(2 \times-$ 0.032 ) to $9.6 \%$ for firms with the highest levels of turnover. This is an economically substantial difference however the coefficient on the interaction term here is statistically insignificant. As expected, book-market ratio and lagged dependent variable are highly significant. For the information uncertainty proxies, the interaction terms are all positive and significant in Panel A. This indicates, for example in model 4, that the financial strength premium increases from 5.8\% (2 $\mathrm{x} 0.029)$ for firms with the highest information uncertainty by $13.8 \%(2 \times 0.069)$ to $19.6 \%$ for firms with the lowest information uncertainty; this is both economically substantial and statistically significant in Panel A. ${ }^{21}$

Table 11 Panel B presents results for the $\mathrm{F}$ rank financial strength indicator. There is a substantial financial strength premium amongst firms with low values of each $\mathrm{X}$ variable. In contrast to Panel $\mathrm{A}$ the interaction terms $\left(\beta_{3}\right)$ for information uncertainty are no longer statistically significant and the magnitude of these effects are small and much smaller than the interaction terms on the liquidity proxies. This suggests a substantial financial strength premium is available regardless of the level of information uncertainty. Amongst liquidity levels, the magnitude of the financial strength premium differs substantially according to the point estimates and is $8-11 \%$ smaller for the most liquid firms as measured by ToR and AvLQ (than the lowest); however, this is only statistically significant for ToR.

Table 12 provides results where the industry-adjusted return is the dependent variable rather than the market adjusted returns. These results generally strongly confirm the results presented in Table 11. The only important difference is that in Table 12 Panel A, the interaction term $\left(\beta_{3}\right)$ becomes significant at the $10 \%$ for ToR and AvLQ indicating that the financial strength

\footnotetext{
${ }^{21}$ Please note that we interpret the estimated magnitudes here for changes from low financial strength to high financial strength. Using these estimates for a change from low to medium financial strength or from medium to high financial strength may not be appropriate since they are being estimated symmetrically across the interval from low financial strength to high financial strength (consistent with an investment strategy which is long in high financial strength firms and short in low financial strength firms).
} 
strategy return is smaller amongst liquid stocks consistent with hypothesis $3 \mathrm{a}$. Thus in Table 12 hypothesis $3 \mathrm{a}$ is supported both in panels $\mathrm{A}$ and $\mathrm{B}$.

We next examine whether there is a flight from illiquidity following a bad signal, hypothesis $3 \mathrm{~b}$, by examining the impact of liquidity on low financial strength firms. These are compared to the effect of liquidity on high financial strength companies and to the impact of information uncertainty. The regressions estimated in Table 13 hence drop the Financial strength dummy variable and interaction terms from equation (6) and are run on sub-samples of firms which have either low financial strength in panels A and B or high financial strength in panels $\mathrm{C}$ and $\mathrm{D}$. Thus they are of the form:

$$
R_{i t+1}=\propto+\beta X_{i t}+\sum_{j=1}^{J} \gamma_{j} Z_{j i t}+\varepsilon_{i t}
$$

Where the key coefficient of interest is the $\beta$ coefficient on the liquidity proxies. If amongst low financial strength companies we can reject the null hypothesis that $\beta=0$ and the coefficient estimate is positive for liquidity proxies then $\mathrm{H} 3 \mathrm{~b}$ is supported; i.e. amongst low financial strength firms more liquid companies earn higher returns than less liquid ones.

Table 13 panel A provides results estimated for firms in the low F-Score group. These indicate that as liquidity increases the stock return increases consistent with the flight from illiquidity hypothesis (H3b). The coefficient is positive and is significant for the ToR and AvLQ measures. For AvLQ the coefficient indicates that a move from the $25^{\text {th }}$ percentile of liquidity to the $75^{\text {th }}$ percentile results in an increase in return of $4.2 \%(0.5 \times 0.086)$. The effect for liquidity is consistent amongst the F-rank indicator also (see panel B) where a $7.7 \%$ increase in return is estimated for a move from firms on the Q1 boundary to the Q3 boundary of liquidity. For information uncertainty, an increase in uncertainty is associated with a reduction in return in both panels A and B, although this is only statistically significant in panel A. The results also indicate that the control variables BM and lagged return have much stronger impact on returns in the low financial strength groups than the full sample.

Table 13 panels $\mathrm{C}$ and $\mathrm{D}$ provide results for the high financial strength groups. These clearly 
indicate that there is at best a weak link between liquidity and return during this group; indicating the flight to liquidity phenomenon is primarily evident following a bad signal. In fact, none of the liquidity proxies are significant in panel $\mathrm{C}$ or $\mathrm{D}$ and the coefficient estimates are each less than half the equivalent value estimated for low financial strength firms. This also supports $\mathrm{H} 3 \mathrm{~b}$, since the hypothesis is that there is a flight from illiquidity amongst low financial strength firms only. There is also no link between information uncertainty and return in the high financial strength firms. In further robustness tests we conducted the same exercises as Table 13 using industry-adjusted returns rather than market adjusted returns as the dependent variable; these results were extremely similar to Table 13 and hence are not reported. Overall there is clear support for the flight from illiquidity hypothesis amongst the financially weak firms only consistent with H3b.

\section{[Insert Tables 11, 12, 13 around here:]}

\section{Conclusions}

The aim of this paper is to analyse the key drivers of the financial strength investment strategy as originally proposed by Piotroski (2000). Based on previous work in the literature, there is reason to assume that the concentration of anomalies in small firms is a large part of their overall success (see for example Fama and French, 2008). However, firm size is regarded as a proxy for different driving forces. To isolate in turn one specific aspect captured by firm size, this paper documented empirical results of the financial strength (FS) investment strategy in relation to information uncertainty (IU) and liquidity (LQ), each of which could slow the speed at which information is incorporated in the stock price. Regarding IU, two different measures - standard deviation and mean absolute deviation of the nine fundamental constituents of the F-Score - were explored. The main focus was thereby to evaluate how IU and liquidity drive the returns of financial strength strategies.

The key findings are as follows. Firm size is connected to the size of profits available to the FS strategy confirming hypothesis 1 . However, the F-Score strategy is still effective in large firms just to a lesser extent than in small firms. Second, F-Score strategy profits overall are not 
consistently or substantially enlarged in high IU stocks. However, firms with high IU and low FScore have weak performance. Hence the part of the second hypothesis that relates to bad news or bad signals is generally confirmed (supporting Zhang, 2006). However, this is also the case once good news hit the market whereas it should be the reverse if IU were a key driver of the F-Score strategy. Furthermore the time-series Sharpe ratio is higher when financial strength strategies are implemented on low uncertainty stocks rather than high because although the strategy return is smaller when IU is low the standard deviation falls even more.

In summary, this paper advances knowledge in two important ways. Firstly, liquidity is a key driver of the financial strength investment strategy. The returns of a long-short portfolio that is based on the FS investment strategy are of larger magnitude amongst illiquid stocks. Consequently, hypothesis $3 \mathrm{a}$ is validated. For example amongst low turnover stocks the F-Score zero investment strategy earns above $20 \%$ on average annually and time-series analysis indicates a Sharpe ratio of about 1.6 can be generated. Secondly, hypothesis $3 \mathrm{~b}$ refers to the flight-from-illiquidity hypothesis, which states that less liquid stocks should underperform their more liquid peers when there is bad news. In this regard, financial strength was utilised as a yardstick to identify bad news. The research findings are in line with this observation and support hypothesis $3 \mathrm{~b}$ regarding a flight from illiquidity. The empirical analysis reveals that amongst low FS companies higher returns are reported for more liquid stocks than less liquid ones; this effect is generally statistically significant and is of substantial economic magnitude. Thus, investors switch to more liquid stocks once they realise the implications of the firm's financial weakness. The resulting price fall could be reinforced by less sophisticated investors, who follow this group. Overall, the results suggest that the financial strength anomaly is exacerbated by a flight from low liquidity firms which are financially weak.

\section{References}

Abarbanell, J., and B. Bushee. 1997. "Fundamental Analysis, Future Earnings, and Stock Prices." Journal of Accounting Research 35 (1): 1 - 24.

Amihud, Y. 2002. "Illiquidity and Stock Returns: Cross-Section and Time-Series Effects." Journal of Financial Markets, 5 (1): 31 - 56.

Amihud, Y., and H. Mendelson. 1986. "Asset Pricing and the Bid-Ask Spread." Journal of 
Financial Economics, 17 (2): 223 - 249.

Andrikopoulos, P., A. Daynes, D. Latimer, and P. Pagas. 2008. "Size Effect, Methodological Issues and 'Risk-to-Default': Evidence from the UK Stock Market." European Journal of Finance, 14 (3-4): 299 - 314.

Asparouhova, E., H. Bessembinder, and I. Kalcheva. 2010. "Liquidity Biases in Asset Pricing Tests." Journal of Financial Economics, 96 (2): 215 - 237.

Baker, M., and J. Wurgler. 2006. "Investor Sentiment and the Cross-Section of Stock Returns." The Journal of Finance, 61 (4): 1645 - 1680.

Bali, T. G., L. Peng, Y. Shen, and Y. Tang. 2014. "Liquidity Shocks and Stock Market Reactions." Review of Financial Studies, 27 (5): 1434 - 1485.

Barber, B. M., and J. D. Lyon. 1997. "Detecting Long-Run Abnormal Stock Returns: The Empirical Power and Specification of Test Statistics." Journal of Financial Economics, 43 (3): $341-372$.

Barton, J., T. B. Hansen, and G. Pownall. 2010. "Which Performance Meassures Do Investors Around the World Value the Most - and Why?" The Accounting Review, 85 (3): 753 -789 .

Benartzi, S., and R. H. Thaler. 2001. "Naïve Diversification Strategies in Defined Contribution Saving Plans." American Economic Review, 91 (1): 79 - 98.

Bhattacharya, N. 2001. "Investors' Trade Size and Trading Responses around Earnings Announcements: An Empirical Investigation." The Accounting Review, 76 (2): 221 - 244.

Brennan, M. J., and A. Subrahmanyam. 1996. "Market Microstructure and Asset Pricing: On the Compensation for Illiquidity in Stock Returns." Journal of Financial Economics, 41 (3): $441-464$.

Choi, N. Y., and R. W. Sias. 2012. "Why Does Financial Strength Forecast Stock Returns?

Evidence from Subsequent Demand by Institutional Investors." Review of Financial Studies, 25 (5): $1550-1587$.

Chordia, T., A. Goyal, G. Sadka, R. Sadka,and L. Shivakumar. 2009. Liquidity and the PostEarnings-Announcement Drift. Financial Analysts Journal, 65(4), 18-32.

Clubb, C., and G. L. Wu. 2014. "Earnings Volatility and Earnings Prediction: Analysis and UK Evidence." Journal of Business Finance \& Accounting, 41 (1-2): 53 - 72.

Datar, V. T., N. Y. Naik, and R. Radcliffe. 1998. "Liquidity and Stock Market Returns: An Alternative Test." Journal of Financial Markets, 1 (2): 203 - 219.

De Bondt, W. F. M., and R. H. Thaler. 1985. "Does the Stock Market Overreact?" The Journal of Finance, 40 (3): $793-805$.

Dechow, P. M., S. A. Richardson, and R. G. Sloan. 2008. "The Persistence and Pricing of the Cash Component of Earnings." Journal of Accounting Research, 46 (3): 537 - 566.

Dichev, I. D., and V. W. Tang. 2009. "Earnings Volatility and Earnings Predictability." Journal of Accounting \& Economics, 47 (1-2): 160 - 181.

Dimson, E., and P. Marsh. 1999. "Murphy's Law and Market Anomalies." Journal of Portfolio Management, 25: 53 - 69.

Duong, C., G. Pescetto, and D. Santamaria. 2014. "How Value-Glamour Investors Use Financial Information: UK Evidence of Investors' Confirmation Bias." The European Journal of Finance, 20 (6): $524-549$.

Duxbury, D., R. Hudson, K. Keasey, Z. Yang, and S. Yao. 2013. "How Prior Realized Outcomes Affect Portfolio Decisions." Review of Quantitative Finance and Accounting, 41 (4): 611 629.

Falkenstein, E. G. 1996. "Preferences for Stock Characteristics as Revealed by Mutual Fund Portfolio Holdings." The Journal of Finance, 51 (1): 111 - 135.

Fama, E. F., and K. R. French. 1988. "Permanent and Temporary Components of Stock Prices." Journal of Political Economy, 96: 246 - 273.

Fama, E. F., and K. R. French. 2006a. "The Value Premium and the CAPM." The Journal of Finance, 61 (5): $2163-2185$. 
Fama, E. F., and K. R. French. 2006b. "Profitability, Investment and Average Returns." Journal of Financial Economics, 82 (3): 491 - 518.

Fama, E. F., and K. R. French. 2008. "Dissecting Anomalies." The Journal of Finance, 63 (4): $1653-1678$.

Fama, E. F., and K. R. French. 2012. "Size, Value, and Momentum in International Stock Returns." The Journal of Finance, 105 (3): 457 - 472.

Finster, M., and M. Wood. 2005. "The Apgar Score Has Survived the Test of Time." Anesthesiology, 102 (4): 855 - 857.

Hasbrouck, J. 2009. "Trading Costs and Returns for U.S. Equities: Estimating Effective Costs from Daily Data." The Journal of Finance, 64 (3): 1445 - 1477.

Haugen, R. A., and N. L. Baker. 1996. "Commonality in the Determinants of Expected Stock Returns." Journal of Financial Economics, 41 (3): 401 - 439.

Hirshleifer, D., K. W. Hou, S. H. Teoh, and Y. L. Zhang. 2004. "Do Investors Overvalue Firms with Bloated Balance Sheets?" Journal of Accounting and Economics, 38 (1-3): 297 $-331$.

Hong, H., T. Lim, and J.C. Stein. 2000. "Bad News Travels Slowly: Size, Analyst Coverage, and the Profitability of Momentum Strategies." The Journal of Finance, 55 (1): 265 $-295$.

Huberman, G., and W. Jiang. 2006. "Offering versus Choice in 401(k) Plans: Equity Exposure and Number of Funds." The Journal of Finance, 61 (2): 763 - 801.

Ivković, Z., and S. Weisbenner. 2007. "Information Diffusion Effects in Individual Investors' Common Stock Purchases: Covet Thy Neighbors' Investment Choices." The Review of Financial Studies, 20 (4): 1327 - 1357.

Jiang, G., C. M. C. Lee, and Y. Zhang. 2005. "Information Uncertainty and Expected Returns." Review of Accounting Studies, 10 (2): 185 - 221.

Karolyi, G. A., K.-H. Lee, and M. A. Van Dijk. 2012. "Understanding Commonality in Liquidity Around the World." Journal of Financial Economics, 105 (1): 82 - 112.

Kothari, S. P., K. Ramanna, and D. J. Skinner. 2010. "Implications for GAAP from an Analysis of Positive Research in Accounting." Journal of Accounting and Economics, 50 (23): $246-286$.

Kothari, S. P., and J. B. Warner. 1997. "Measuring Long-Horizon Security Price Performance." Journal of Financial Economics, 43 (3): 301 - 339.

Kumar, A. (2009). "Who Gambles in the Stock Market?" The Journal of Finance, 64 (4): $1889-1933$.

Lev, B., and R. Thiagarajan, R. 1993. "Fundamental Information Analysis." Journal of Accounting Research, 31 (2): 190 - 215.

Liu, W. 2006. "A Liquidity-Augmented Capital Asset Pricing Model." Journal of Financial Economics, 82 (3): $631-671$.

Longstaff, F. A. 2009. "Portfolio Claustrophobia: Asset Pricing in Markets with Illiquid Assets." The American Economic Review, 99 (4): 1119 - 1144.

Mann, H. B., and D. R. Whitney. 1947. "On a Test of Whether One of Two Random Variables is Stochastically Larger than the Other." The Annals of Mathematical Statistics, 18 (1): $50-60$.

Mohanram, P. S. 2005. "Separating Winners from Losers among Low Book-to-Market Stocks Using Financial Statement Analysis." Review of Accounting Studies, 10 (2-3): 133 170.

Mood, A. M. 1950. "Introduction to the Theory of Statistics." New York: McGraw-Hill.

Næs, R., J. A. Skjeltorp, and B. A. Ødegaard. 2011. "Stock Market Liquidity and the Business Cycle." The Journal of Finance, 66 (1): 139 - 176.

Neave, H. R., and P. L. Worthington. 1988. "Distribution-Free Tests." London: Unwin Hyman.

Ng, L., and F. Wu. 2006. "Revealed Stock Preferences of Individual Investors: Evidence from 
Chinese Equity Markets." Pacific-Basin Finance Journal, 14 (2): 175 - 192.

Financial Management, 39 (2): 807 - 831.

Ng, L., and F. Wu. 2010. "Peer Effects in the Trading Decisions of Individual Investors." Financial Management, 39 (2): 807 - 831.

O'Hara, M. 2008. "Bubbles: Some Perspectives (and Loose Talk) from History." Review of Financial Studies, 21 (1): $11-17$.

Ou, J. A., and S. H. Penman. 1989. "Financial Statement Analysis and the Prediction of Stock Returns." Journal of Accounting and Economics, 11 (4): 295 - 329.

Piotroski, J. D. 2000. "Value Investing: The Use of Historical Financial Statement Information to Separate Winners from Losers." Journal of Accounting Research, 38: 1 - 41.

Poterba, J., and L. H. Summers. 1988. "Mean Reversion in Stock Prices: Evidence and Implications." Journal of Financial Economics, 22 (1): 27 - 59.

Richardson, S., I. Tuna, and P. Wysocki. 2010. "Accounting Anomalies and Fundamental Analysis: A Review of Recent Research Advances." Journal of Accounting and Economics, 50 (2-3): $410-454$.

Sadka, R. 2006. "Momentum and Post-Earnings-Announcement Drift Anomalies: The Role of Liquidity Risk." Journal of Financial Economics, 80 (2): 309 - 349.

Silber, W. L. 1992. "Discounts on Restricted Stock: The Impact of Illiquidity on Stock Prices." Financial Analysts Journal, 47 (4): 60 - 64.

Spiegel, M. I., and X. Wang. 2005. "Cross-Sectional Variation in Stock Returns: Liquidity and Idiosyncratic Risk." Yale ICF Working Paper No. 05-13. Available at SSRN.

Wilcoxon, F. 1945. "Individual Comparisons by Ranking Methods." Biometrics Bulletin, 1 (6): $80-83$.

Zhang, X. F. 2006. "Information Uncertainty and Stock Returns." The Journal of Finance, 61 (1): $105-136$.

Zhang, X. F. 2007. "Accruals, Investment, and the Accrual Anomaly." The Accounting Review, 82 (5): 1333 - 1363. 
0
$\stackrel{0}{0}$
o
0
$m$
0
0
0
0

$\infty$

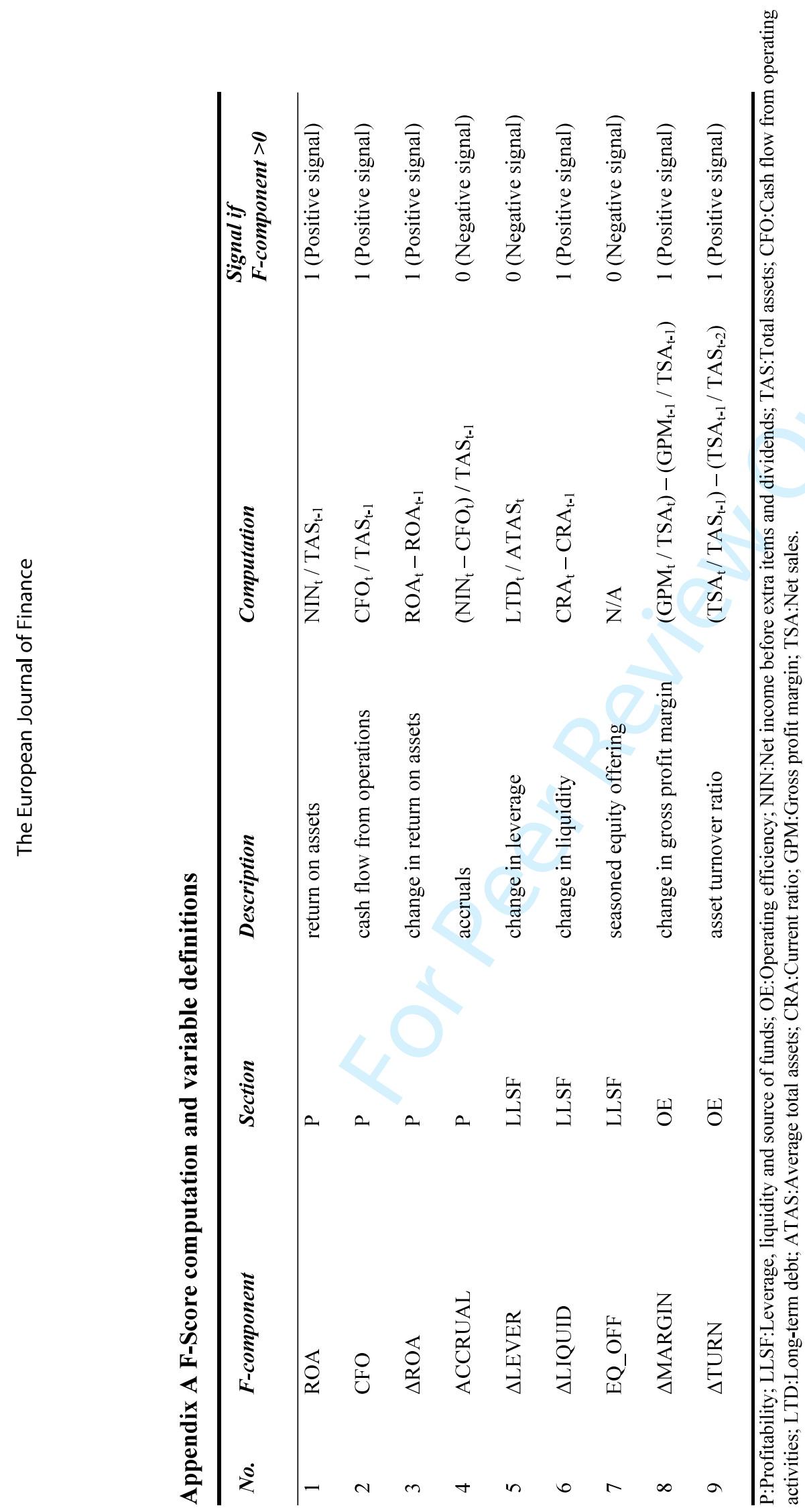


Table 1. F-Score Descriptive statistics.

Panel A: UK firm years of the F-Score.

\begin{tabular}{|c|c|c|c|c|c|}
\hline F-Score & Freq. & Percent. & Cum. Percent. & \multicolumn{2}{|c|}{ Grouping } \\
\hline 0 & 13 & 0.06 & 0.06 & \multirow{4}{*}{\multicolumn{2}{|c|}{$\mathrm{L}^{*}$}} \\
\hline 1 & 203 & 1.01 & 1.08 & & \\
\hline 2 & 875 & 4.36 & 5.44 & & \\
\hline 3 & 2,177 & 10.86 & 16.30 & & \\
\hline 4 & 4,091 & 20.40 & 36.70 & \multirow{3}{*}{ M } & \multirow{3}{*}{ M } \\
\hline 5 & 4,875 & 24.31 & 61.01 & & \\
\hline 6 & 4,109 & 20.49 & 81.50 & & \\
\hline 7 & 2,550 & 12.72 & 94.22 & \multirow{4}{*}{$\mathrm{H}^{*}$} & \multirow{4}{*}{$\mathrm{H}$} \\
\hline 8 & 999 & 4.98 & 99.20 & & \\
\hline 9 & 161 & 0.80 & 100 & & \\
\hline Total & 20,053 & 100 & & & \\
\hline
\end{tabular}

Notes: Firm years are defined as the cumulative number of firms that provide a full set of relevant accounting data for the period 1992 to 2010 . The cut-off points remain constant and follow a cumulative distribution such that approximately L*:5\%; L:20\%; M:60\%; H:20\%; H*:5\%.

Panel B: UK firm years of the F-Score portfolios by year.

\begin{tabular}{lcccccc}
\hline $\begin{array}{l}\text { Account } \\
\text { Year }\end{array}$ & $\boldsymbol{L}^{*}$ & $\boldsymbol{L}$ & $\boldsymbol{M}$ & $\boldsymbol{H}$ & $\boldsymbol{H}^{*}$ & $\begin{array}{c}\text { Total } \\
(\boldsymbol{L}+\boldsymbol{M}+\boldsymbol{H})\end{array}$ \\
\hline 1992 & 0 & 3 & 12 & 4 & 0 & 19 \\
1993 & 1 & 7 & 27 & 29 & 8 & 63 \\
1994 & 22 & 71 & 398 & 151 & 45 & 620 \\
1995 & 41 & 157 & 808 & 199 & 56 & 1164 \\
1996 & 42 & 154 & 794 & 196 & 54 & 1144 \\
1997 & 28 & 116 & 772 & 237 & 77 & 1125 \\
1998 & 51 & 144 & 732 & 193 & 56 & 1069 \\
1999 & 50 & 173 & 770 & 215 & 78 & 1158 \\
2000 & 71 & 216 & 698 & 188 & 53 & 1102 \\
2001 & 91 & 280 & 758 & 173 & 55 & 1211 \\
2002 & 87 & 230 & 785 & 218 & 70 & 1233 \\
2003 & 56 & 154 & 764 & 277 & 98 & 1195 \\
2004 & 61 & 179 & 790 & 295 & 81 & 1264 \\
2005 & 95 & 238 & 875 & 253 & 69 & 1366 \\
2006 & 105 & 275 & 878 & 240 & 63 & 1393 \\
2007 & 101 & 279 & 896 & 198 & 68 & 1373 \\
2008 & 83 & 269 & 831 & 160 & 44 & 1260 \\
2009 & 65 & 208 & 805 & 179 & 66 & 1192 \\
2010 & 41 & 115 & 682 & 305 & 119 & 1102 \\
Total & $\mathbf{1 , 0 9 1}$ & $\mathbf{3 , 2 6 8}$ & $\mathbf{1 3 , 0 7 5}$ & $\mathbf{3 , 7 1 0}$ & $\mathbf{1 , 1 6 0}$ & $\mathbf{2 0 , 0 5 3}$ \\
\hline
\end{tabular}

Notes: Number of firms in each portfolio by year. Please note that the $\mathrm{L}^{*}$ firms are also included in the $\mathrm{L}$ portfolio and the $\mathrm{H}^{*}$ firms are also included in the $\mathrm{H}$ portfolio. Thus, the total number of firms per year is given by the sum of $\mathrm{L}, \mathrm{M}$ and $\mathrm{H}$.

Panel C. Comparison of one-year buy-and-hold returns.

\begin{tabular}{lcccccccc}
\hline \multicolumn{1}{c}{ Returns } & Mean & $\boldsymbol{P}_{\mathbf{1 0}}$ & $\boldsymbol{P}_{\mathbf{2 5}}$ & Median & $\boldsymbol{P}_{\mathbf{7 5}}$ & $\boldsymbol{P}_{\boldsymbol{9 0}}$ & Fract. $+\boldsymbol{v e}$ & S.D. \\
\hline US & 0.059 & -0.560 & -0.317 & -0.061 & 0.255 & 0.708 & 0.437 & - \\
UK & 0.000 & -0.558 & -0.306 & -0.048 & 0.229 & 0.542 & 0.451 & 0.511 \\
\multicolumn{2}{l}{ F-Score portfolios } & & & & & & & \\
UK H* & 0.078 & -0.415 & -0.207 & 0.026 & 0.269 & 0.581 & 0.526 & 0.465 \\
UK H & 0.054 & -0.433 & -0.211 & 0.013 & 0.250 & 0.540 & 0.515 & 0.449 \\
UK M & 0.011 & -0.532 & -0.288 & -0.040 & 0.234 & 0.543 & 0.459 & 0.507 \\
UK L & -0.104 & -0.706 & -0.477 & -0.183 & 0.144 & 0.529 & 0.347 & 0.576 \\
UK L* & -0.142 & -0.749 & -0.536 & -0.221 & 0.100 & 0.456 & 0.315 & 0.604 \\
\hline
\end{tabular}

Notes: The top section presents one year buy and hold returns for the UK for the period 1992 to 2010 compared to Piotroski (2000) results for the US over 1976-1996. The following section presents one year buy and hold returns for the F-score portfolios and the final section presents one year buy and hold returns for the F-rank portfolios. $\mathrm{P}_{\mathrm{x}}$ is the xth percentile of the return. Fract. +ve is the proportion of positive returns. S.D. is the standard 
deviation.

Table 2. Portfolio descriptive statistics.

Panel A: Characteristics of the F-Score portfolios (and the F-rank portfolios).

\begin{tabular}{lcccccc}
\hline \multirow{4}{*}{ Size } & & $\boldsymbol{L}^{*}$ & $\boldsymbol{L}$ & $\boldsymbol{M}$ & $\boldsymbol{H}$ & $\boldsymbol{H}^{*}$ \\
& Av. & 0.579 & 0.556 & 0.451 & 0.494 & 0.555 \\
& SD & 0.259 & 0.274 & 0.287 & 0.280 & 0.277 \\
SDF & Obs & 1,045 & 3,163 & 12,751 & 3,571 & 1,108 \\
& Av. & 0.496 & 0.547 & 0.511 & 0.416 & 0.362 \\
& SD & 0.306 & 0.302 & 0.291 & 0.252 & 0.234 \\
MADF & Obs & 1,091 & 3,268 & 13,075 & 3,710 & 1,160 \\
& Av. & 0.463 & 0.523 & 0.519 & 0.410 & 0.348 \\
AMI & SD & 0.300 & 0.299 & 0.290 & 0.256 & 0.229 \\
& Obs & 1,091 & 3,268 & 13,075 & 3,710 & 1,160 \\
& Av. & 0.611 & 0.585 & 0.475 & 0.508 & 0.562 \\
ToR & SD & 0.256 & 0.272 & 0.291 & 0.281 & 0.274 \\
& Obs & 1,008 & 2,984 & 11,283 & 3,044 & 952 \\
& Av. & 0.453 & 0.458 & 0.514 & 0.485 & 0.447 \\
& SD & 0.303 & 0.299 & 0.287 & 0.283 & 0.284 \\
& Obs & 1,009 & 2,998 & 11,345 & 3,061 & 959 \\
\hline
\end{tabular}

Notes: This table reports the average rank for each characteristic by portfolio. The ranks are bounded between 0 and 1.

Panel B: Two-way Portfolios (Average number of stocks per year 1994-2010).

\begin{tabular}{ccccc}
\hline & $\boldsymbol{S L}$ & $\boldsymbol{S H}$ & $\boldsymbol{B L}$ & $\boldsymbol{B H}$ \\
\hline Size & 40.88 & 56.29 & 77.18 & 70.06 \\
\hline & $\boldsymbol{I U 1 \boldsymbol { L }}$ & $\boldsymbol{I U 1 \boldsymbol { H }}$ & $\boldsymbol{I U 3 \boldsymbol { L }}$ & $\boldsymbol{I U 3 \boldsymbol { H }}$ \\
\hline $\boldsymbol{S D F}$ & 52.47 & 82.76 & 77.82 & 39.29 \\
$\boldsymbol{M A D F}$ & 58.06 & 85.24 & 69.82 & 39.35 \\
\hline & $\boldsymbol{L Q 1 \boldsymbol { L }}$ & $\boldsymbol{L Q 1 ~ H}$ & $\boldsymbol{L Q 3 \boldsymbol { L }}$ & $\boldsymbol{L Q 3 ~} \boldsymbol{H}$ \\
\hline $\boldsymbol{A M I}$ & 38.06 & 48.53 & 90.88 & 92.71 \\
$\boldsymbol{T o R}$ & 60.88 & 54.29 & 60.41 & 80.53 \\
\hline
\end{tabular}

Notes: These are the number of firms on average in each of the two-way independently sorted portfolios. $\mathrm{S}=$ Small market capitalisation, $\mathrm{B}=\mathrm{Big}$ market capitalisation, IU1=low information uncertainty, IU3=high information uncertainty; LQ1= illiquid firms; LQ3 = liquid firms. SDF is the standard deviation of the F-rank measure of information uncertainty and MADF is the mean absolute deviation of the F-rank measure of information uncertainty. AMI is groups formed on the Amihud measure and ToR is groups formed on the Turnover ratio. 
Panel C: Migration across F-Score portfolios.

\begin{tabular}{|c|c|c|c|c|c|c|c|c|}
\hline \multirow[t]{8}{*}{ Size } & & $S L$ & $S H$ & $B L$ & BH & Other & Dis & Total \\
\hline & $S L$ & $\begin{array}{c}16.1 \\
(12.9)\end{array}$ & $\begin{array}{c}9.8 \\
(14.3)\end{array}$ & $\begin{array}{c}0.8 \\
(0.1)\end{array}$ & $\begin{array}{c}0.1 \\
(0.0)\end{array}$ & $\begin{array}{r}63.6 \\
(685)\end{array}$ & $\begin{array}{c}9.6 \\
(4.2)\end{array}$ & $\begin{array}{c}100 \\
(100)\end{array}$ \\
\hline & $S H$ & 4.8 & 25.3 & 0.1 & 0.0 & 63.6 & 6.2 & 100 \\
\hline & & (2.6) & (29.7) & $(0.0)$ & $(0.0)$ & (61.7) & (6.0) & (100) \\
\hline & $B L$ & 0.0 & 0.0 & 19.5 & 9.4 & 53.4 & 17.7 & 100 \\
\hline & & $(0.0)$ & $(0.0)$ & (20.0) & $(10.0)$ & (54.8) & $(15.2)$ & $(100)$ \\
\hline & BH & 0.0 & 0.0 & 7.8 & 25.2 & 55.0 & 12.0 & 100 \\
\hline & & $(0.0)$ & $(0.0)$ & (6.2) & (22.6) & (60.3) & (10.9) & (100) \\
\hline \multirow[t]{9}{*}{ SDF } & & IU1 L & IUI H & IU3 $L$ & IUS H & Other & Dis & Total \\
\hline & IU1 L & 8.6 & 6.2 & 2.9 & 1.6 & 67.0 & 13.7 & 100 \\
\hline & & (5.0) & (3.8) & $(0.8)$ & (5.5) & (78.7) & (6.2) & (100) \\
\hline & IUI H & 2.5 & 17.5 & 1.7 & 1.9 & 67.4 & 9.0 & 100 \\
\hline & & $(0.5)$ & (21.3) & $(0.2)$ & $(0.1)$ & (76.5) & (1.4) & (100) \\
\hline & IU3 L & 4.0 & 1.5 & 18.1 & 2.9 & 59.6 & 13.9 & 100 \\
\hline & & (4.0) & $(0.4)$ & (10.8) & (1.8) & (77.9) & (5.1) & (100) \\
\hline & IU $3 \mathrm{H}$ & 2.2 & 5.0 & 4.8 & 7.8 & 70.9 & 9.3 & 100 \\
\hline & & $(0.3)$ & (1.0) & $(0.4)$ & $(0.9)$ & (92.) & (4.8) & $(100)$ \\
\hline \multirow[t]{9}{*}{ MADF } & & IU1 L & IUI H & IU3 L & IUS H & Other & Dis & Total \\
\hline & $I U 1 L$ & 9.0 & 5.5 & 2.7 & 2.3 & 65.7 & 14.8 & 100 \\
\hline & & (4.8) & (3.6) & $(0.8)$ & (5.6) & (79.3) & (5.9) & (100) \\
\hline & IUI H & 2.7 & 16.9 & 1.8 & 1.6 & 68.8 & 8.2 & 100 \\
\hline & & $(0.6)$ & (19.8) & $(0.2)$ & $(1.8)$ & (76.5) & (1.1) & (100) \\
\hline & IUS L & 5.2 & 1.5 & 15.4 & 2.7 & 61.9 & 13.3 & 100 \\
\hline & & (6.9) & $(0.4)$ & $(9.2)$ & (2.0) & (76.0) & (5.5) & (100) \\
\hline & IU $3 \mathrm{H}$ & 3.2 & 6.7 & 4.6 & 7.5 & 69.1 & 8.9 & 100 \\
\hline & & $(0.3)$ & $(0.9)$ & $(0.3)$ & (4.9) & (89.6) & (4.0) & $(100)$ \\
\hline \multirow[t]{9}{*}{ AMI } & & $L Q 3 L$ & $L Q 3 H$ & $L Q 1 L$ & $L Q 1 H$ & Other & Dis & Total \\
\hline & $L Q 3 L$ & 15.5 & 9.5 & 0.5 & 0.0 & 63.4 & 11.1 & 100 \\
\hline & & (11.3) & (14.3) & $(0.0)$ & $(0.0)$ & (70.5) & (3.9) & (100) \\
\hline & $L Q 3 H$ & 3.9 & 23.3 & 0.1 & 0.3 & 72.5 & 6.2 & 100 \\
\hline & & (2.5) & $(29.0)$ & $(0.0)$ & $(0.0)$ & (62.2) & (6.3) & (100) \\
\hline & $L Q 1 L$ & 0.1 & 0.1 & 18.8 & 8.3 & 72.5 & 16.4 & 100 \\
\hline & & $(0.1)$ & $(0.7)$ & (12.3) & (6.4) & (62.3) & (18.2) & (100) \\
\hline & $L Q 1 \mathrm{H}$ & 0.1 & 0.6 & 6.9 & 20.7 & 60.7 & 11.0 & 100 \\
\hline & & $(0.0)$ & (32.9) & (1.0) & (14.8) & (48.6) & (2.7) & $(100)$ \\
\hline \multirow[t]{9}{*}{ ToR } & & $L Q 3 L$ & LQ3H & $L Q 1 L$ & $L Q 1 H$ & Other & Dis & Total \\
\hline & $L Q 3 L$ & 19.0 & 6.8 & 2.5 & 0.9 & 49.6 & 12.2 & 100 \\
\hline & & $(15.4)$ & $(10.9)$ & (1.9) & $(0.1)$ & (65.5) & (6.2) & (100) \\
\hline & LQ3 $H$ & 5.7 & 21.3 & 0.6 & 2.1 & 59.9 & 10.4 & 100 \\
\hline & & (1.7) & $(20.0)$ & (7.2) & $(28.0)$ & (39.0) & (4.1) & (100) \\
\hline & $L Q 1 L$ & 1.2 & 0.8 & 12.6 & 7.3 & 78.2 & 16.3 & 100 \\
\hline & & $(0.1)$ & $(0.0)$ & (4.9) & (11.2) & (83.7) & (5.7) & (100) \\
\hline & $L Q 1 \mathrm{H}$ & 1.2 & 2.0 & 4.1 & 21.1 & 62.2 & 9.4 & 100 \\
\hline & & $(0.0)$ & $(0.2)$ & (1.4) & $(24.0)$ & $(71.0)$ & (3.4) & (100) \\
\hline
\end{tabular}

Notes: The first entry in each row is the percentage of the number of firms that move across portfolios. Values in parentheses indicate the percentage of the market capitalisation of the firms that move across portfolios within one year. Abbreviations are as follows with the first part relating to the Size/IU/LQ sort and the second part relating to the F-Score sort: Size: $\mathrm{SL}=$ Small/Low (F-Score), $\mathrm{SH}=$ Small/High, $\mathrm{BL}=\mathrm{Big} / \mathrm{Low}, \mathrm{BH}=\mathrm{Big} / \mathrm{High}$. SDF/MADF: IU1 L=Low (uncertainty)/Low (F-Score), IU1 H=Low/High, IU3 L=High/Low, IU3 $\mathrm{H}=$ High/High. AMI/ToR: LQ3 L=High (liquidity)/Low (F-Score), LQ3 H=High/High, LQ1 L=Low/Low, LQ1 $\mathrm{H}=$ Low/High. Other $=$ transfer to another portfolio not reported here, i.e. Neutral Financial Strength or Medium on the Size / IU/ LQ indicator or both. Dis=Dissolved. 
Table 3. Two-way F-Score/F-rank-size portfolios.

\begin{tabular}{|c|c|c|c|c|c|c|c|c|c|c|}
\hline \multirow{2}{*}{$\begin{array}{l}\underline{\text { A.1 }} \\
\text { Size }\end{array}$} & \multicolumn{4}{|c|}{ F-Score portfolio mean returns } & \multicolumn{2}{|c|}{$\begin{array}{c}\text { F-Score strategy } \\
\text { returns, } t \text {-test }\end{array}$} & \multicolumn{2}{|c|}{$\begin{array}{c}\text { F-Score strategy } \\
M W W \text { test }\end{array}$} & \multicolumn{2}{|c|}{ Mood } \\
\hline & $\mathrm{L}^{*}$ & $\mathrm{~L}$ & $\mathrm{H}$ & $\mathrm{H}^{*}$ & $\mathrm{H}-\mathrm{L}$ & $\mathrm{H}^{*}-\mathrm{L}^{*}$ & $\mathrm{H}-\mathrm{L}$ & $\mathrm{H}^{*}-\mathrm{L}^{*}$ & $\mathrm{H}-\mathrm{L}$ & $\mathrm{H}^{*}-\mathrm{L}^{*}$ \\
\hline $\mathrm{S}$ & -0.132 & -0.110 & 0.072 & 0.104 & $\begin{array}{l}.182^{* * * *} \\
(7.86)\end{array}$ & $\begin{array}{l}.236^{* * *} \\
(6.13)\end{array}$ & {$[11.14]^{* * *}$} & {$[8.46]^{* * *}$} & 2 & 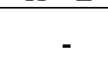 \\
\hline $\mathrm{B}$ & -0.101 & -0.070 & 0.046 & 0.049 & $\begin{array}{l}.116^{* * *} \\
(6.15)\end{array}$ & $\begin{array}{l}.150 * * * \\
(3.62)\end{array}$ & {$[7.24]^{* * *}$} & {$[4.76]^{* * *}$} & - & - \\
\hline $\begin{array}{c}\boldsymbol{B}-\boldsymbol{S} \\
\text { t-test } \\
\text { MWW }\end{array}$ & $\begin{array}{l}.031 \\
(0.58) \\
{[1.84]^{*}}\end{array}$ & $\begin{array}{l}.040 \\
(1.49) \\
{[4.59]^{* * *}}\end{array}$ & $\begin{array}{l}-.026 \\
(-1.40) \\
{[2.35]^{* *}}\end{array}$ & $\begin{array}{l}-.055 \\
(-1.47) \\
{[0.67]}\end{array}$ & & & & & & \\
\hline$\underline{\mathrm{A} .2}$ & \multicolumn{4}{|c|}{ F-Score portfolios median returns } & \multicolumn{2}{|c|}{ t-test } & \multicolumn{2}{|c|}{$M W W$} & \multicolumn{2}{|c|}{$\begin{array}{c}\text { F-Score strategy } \\
\text { returns, Mood }\end{array}$} \\
\hline Size & $\mathrm{L}^{*}$ & $\mathrm{~L}$ & $\mathrm{H}$ & $\mathrm{H}^{*}$ & $\mathrm{H}-\mathrm{L}$ & $\mathrm{H}^{*}-\mathrm{L}^{*}$ & $\mathrm{H}-\mathrm{L}$ & $\mathrm{H}^{*}-\mathrm{L}^{*}$ & $\mathrm{H}-\mathrm{L}$ & $\mathrm{H}^{*}-\mathrm{L}^{*}$ \\
\hline $\mathrm{S}$ & -0.230 & -0.210 & -0.016 & 0.003 & - & - & - & - & $\begin{array}{l}.194 * * * \\
(100.11)\end{array}$ & $\begin{array}{l}.233 * * * \\
(55.69)\end{array}$ \\
\hline B & -0.137 & -0.079 & 0.037 & 0.051 & - & - & - & - & $\begin{array}{l}.116^{* * *} \\
(29.40)\end{array}$ & $\begin{array}{l}.188^{* * *} \\
(11.10)\end{array}$ \\
\hline $\begin{array}{c}\boldsymbol{B}-\boldsymbol{S} \\
\text { Mood }\end{array}$ & $\begin{array}{l}.093 * * \\
(4.48) \\
\end{array}$ & $\begin{array}{l}.131 * * * \\
(20.42)\end{array}$ & $\begin{array}{l}.053^{* * *} \\
(9.89)\end{array}$ & $\begin{array}{l}0.048 \\
(1.72) \\
\end{array}$ & & & & & & \\
\hline$\underline{B .1}$ & \multicolumn{4}{|c|}{ F-rank (mean) portfolios mean returns } & \multicolumn{2}{|c|}{$\begin{array}{c}\text { F-rank strategy } \\
\text { returns, t-test }\end{array}$} & \multicolumn{2}{|c|}{$\begin{array}{c}F-\text { rank strategy } \\
M W W \text { test }\end{array}$} & \multicolumn{2}{|c|}{ Mood } \\
\hline Size & $\mathrm{L}^{*}$ & $\mathrm{~L}$ & $\mathrm{H}$ & $\mathrm{H}^{*}$ & $\mathrm{H}-\mathrm{L}$ & $\mathrm{H}^{*}-\mathrm{L}^{*}$ & $\mathrm{H}-\mathrm{L}$ & $\mathrm{H}^{*}-\mathrm{L}^{*}$ & $\mathrm{H}-\mathrm{L}$ & $\mathrm{H}^{*}-\mathrm{L}^{*}$ \\
\hline $\mathrm{S}$ & -0.127 & -0.090 & 0.049 & 0.083 & $\begin{array}{l}.139 * * * \\
(6.32)\end{array}$ & $\begin{array}{l}.210^{* * *} \\
(4.82)\end{array}$ & {$[10.25]^{* * *}$} & {$[7.59]^{* * *}$} & - & - \\
\hline B & -0.048 & -0.026 & 0.039 & 0.051 & $\begin{array}{l}.065 * * * \\
(3.51)\end{array}$ & $\begin{array}{l}.099^{*} \\
(1.88)\end{array}$ & {$[4.25]^{* * *}$} & {$[3.17]^{* * *}$} & - & - \\
\hline $\begin{array}{c}B-S \\
\text { t-test }\end{array}$ & $\begin{array}{l}.079 \\
(1.34)\end{array}$ & $\begin{array}{l}.064 * * * \\
(2.83)\end{array}$ & $\begin{array}{l}-.010 \\
(-0.46)\end{array}$ & $\begin{array}{l}-.032 \\
(-0.70)\end{array}$ & & & & & & \\
\hline MWW & {$[2.76]^{* * *}$} & {$[7.99]^{* * *}$} & $\underset{*}{[2.67]^{* *}}$ & {$[0.46]$} & & & & & & \\
\hline$\underline{\text { B.2 }}$ & F-rank & ean) portfo & os media & returns & & & & $V W$ & $\begin{array}{l}\text { F-rank } \\
\text { returns }\end{array}$ & $\begin{array}{l}\text { Mategy } \\
\text { Mood }\end{array}$ \\
\hline Size & $\mathrm{L}^{*}$ & $\mathrm{~L}$ & $\mathrm{H}$ & $\mathrm{H}^{*}$ & $\mathrm{H}-\mathrm{L}$ & $\mathrm{H}^{*}-\mathrm{L}^{*}$ & $\mathrm{H}-\mathrm{L}$ & $\mathrm{H}^{*}-\mathrm{L}^{*}$ & H-L & $\mathrm{H}^{*}-\mathrm{L}^{*}$ \\
\hline$S$ & -0.231 & -0.207 & -0.031 & -0.008 & & & - & - & $\begin{array}{l}.175^{* * *} \\
(78.35)\end{array}$ & $\begin{array}{l}.223 * * * \\
(42.94)\end{array}$ \\
\hline B & -0.116 & -0.042 & 0.019 & 0.019 & - & & - & - & $\begin{array}{l}.061 * * * \\
(10.63)\end{array}$ & $\begin{array}{l}.135^{* *} \\
(4.78)\end{array}$ \\
\hline $\begin{array}{c}B-\boldsymbol{S} \\
\text { Mood }\end{array}$ & $\begin{array}{l}.115^{* * *} \\
(7.90)\end{array}$ & $\begin{array}{l}.165^{* * *} \\
(70.04)\end{array}$ & $\begin{array}{l}.050^{* *} \\
(7.50)\end{array}$ & $\begin{array}{l}0.027 \\
(1.01)\end{array}$ & & & & & & \\
\hline
\end{tabular}

Notes: Panels A.1 and B.1 report the winsorised mean returns and panels A.2 and B.2 the winsorised median portfolio returns in relation to firm size where: $B=b i g ; S=$ small. Financial strength is measured by the F-Score and the F-rank. Portfolios are independently sorted on Financial strength and on Size, thus the order of sorting is irrelevant. $\mathrm{L}^{*}$ is a portfolio which contains (approximately) the lowest $5 \%$ of firms by Financial strength. Portfolio L contains (approximately) the $20 \%$ of firms with low Financial strength. Portfolio H contains (approximately) the $20 \%$ of firms with high Financial strength. $\mathrm{H}^{*}$ is a portfolio which contains (approximately) the highest $5 \%$ of firms by Financial strength. H-L is a zero investment financial strength strategy return, which takes a long position in the high financial strength firms and a short position in low financial strength firms. T-test reported in parentheses are parametric unpaired two-sample t-tests. MWW is the Mann-Whitney-Wilcoxon non-parametric version of the t-test reported in brackets. Median tests reported in parentheses are based on Mood's (1950) nonparametric median test for two independent samples. These tests are applied to the Financial Strength strategy returns as well as to test for differences between size portfolios holding financial strength constant (B-S). All returns are reported in decimals; so, for example, in Panel A.1 for Small firms the H-L financial strength strategy return is .182 which is $18.2 \%$. 
Table 4. Two-way F-Score/F-rank-SDF portfolios.

\begin{tabular}{|c|c|c|c|c|c|c|c|c|c|c|}
\hline \multirow{2}{*}{$\begin{array}{l}\underline{\mathbf{A . 1}} \\
\text { SDF }\end{array}$} & \multicolumn{4}{|c|}{ F-Score portfolios, mean returns } & \multicolumn{2}{|c|}{$\begin{array}{c}\text { F-Score strategy } \\
\text { returns, t-test }\end{array}$} & \multicolumn{2}{|c|}{$\begin{array}{c}\text { F-Score strategy } \\
\text { MWW test }\end{array}$} & \multicolumn{2}{|c|}{ Mood median } \\
\hline & $\mathrm{L}^{*}$ & $\mathrm{~L}$ & $\mathrm{H}$ & $\mathrm{H}^{*}$ & $\mathrm{H}-\mathrm{L}$ & $\mathrm{H}^{*}-\mathrm{L}^{*}$ & $\mathrm{H}-\mathrm{L}$ & $\mathrm{H}^{*}-\mathrm{L}^{*}$ & $\mathrm{H}-\mathrm{L}$ & $\mathrm{H}^{*}-\mathrm{L}^{*}$ \\
\hline $\begin{array}{l}\text { IU1 } \\
\text { (Low) }\end{array}$ & -0.134 & -0.069 & 0.054 & 0.059 & $\begin{array}{l}.123 * * * \\
(6.53)\end{array}$ & $\begin{array}{l}.193 * * * \\
(5.87)\end{array}$ & {$[8.40]^{* * *}$} & {$[7.32]^{* * *}$} & - & - \\
\hline $\begin{array}{l}\text { IU3 } \\
\text { (High) }\end{array}$ & -0.148 & -0.134 & 0.034 & 0.107 & $\begin{array}{l}.168^{* * *} \\
(6.18)\end{array}$ & $\begin{array}{l}.255^{* * *} \\
(4.17)\end{array}$ & {$[8.42]^{* * *}$} & {$[5.71]^{* * *}$} & - & - \\
\hline $\begin{array}{l}\text { IU3- } \\
\text { IU1 }\end{array}$ & -.014 & $-.065 * * *$ & -.020 & .048 & & & & & & \\
\hline $\begin{array}{l}\text { t-test } \\
\text { MWW }\end{array}$ & $\begin{array}{r}(-0.31) \\
{[-1.61]}\end{array}$ & $\begin{array}{l}(-2.63) \\
{[-5.00]^{* * *}}\end{array}$ & $\begin{array}{c}(-0.99) \\
{[-3.01] * * *}\end{array}$ & $\begin{array}{r}(1.11) \\
{[0.54]} \\
\end{array}$ & & & & & & \\
\hline$\underline{\mathbf{A . 2}}$ & \multicolumn{4}{|c|}{ F-Score portfolios, median returns } & \multicolumn{2}{|c|}{ t-test } & \multicolumn{2}{|c|}{$M W W$} & \multicolumn{2}{|c|}{$\begin{array}{l}\text { F-Score strateg] } \\
\text { returns, Mood }\end{array}$} \\
\hline SDF & $\mathrm{L}^{*}$ & $\mathrm{~L}$ & $\mathrm{H}$ & $\mathrm{H}^{*}$ & $\mathrm{H}-\mathrm{L}$ & $\mathrm{H}^{*}-\mathrm{L}^{*}$ & $\mathrm{H}-\mathrm{L}$ & $\mathrm{H}^{*}-\mathrm{L}^{*}$ & $\mathrm{H}-\mathrm{L}$ & $\mathrm{H}^{*}-\mathrm{L}^{*}$ \\
\hline $\begin{array}{l}\text { IU1 } \\
\text { (Low) }\end{array}$ & -0.202 & -0.129 & 0.020 & 0.013 & - & - & - & - & $\begin{array}{l}.149^{* * *} \\
(38.67)\end{array}$ & $\begin{array}{l}.215 * * * \\
(33.10)\end{array}$ \\
\hline $\begin{array}{l}\text { IU3 } \\
\text { (High) }\end{array}$ & -0.262 & -0.230 & -0.044 & 0.043 & - & - & - & - & $\begin{array}{l}.186^{* * *} \\
(46.09)\end{array}$ & $\begin{array}{l}.305^{* * *} \\
(24.69)\end{array}$ \\
\hline $\begin{array}{c}\text { IU3- } \\
\text { IU1 } \\
\text { Mood }\end{array}$ & $\begin{array}{l}-.060^{* *} \\
(-4.03) \\
\end{array}$ & $\begin{array}{l}-.101 * * * \\
(-24.87) \\
\end{array}$ & $\begin{array}{l}-.064 * * * \\
(-8.74)\end{array}$ & $\begin{array}{l}0.030 \\
(0.70)\end{array}$ & & & & & & \\
\hline$\underline{B .1}$ & \multicolumn{4}{|c|}{ F-rank (mean) portfolios, mean returns } & \multicolumn{2}{|c|}{$\begin{array}{c}\text { F-rank strategy } \\
\text { returns, } t \text {-test }\end{array}$} & \multicolumn{2}{|c|}{$\begin{array}{c}\text { F-rank strategy } \\
\text { MWW test }\end{array}$} & \multicolumn{2}{|c|}{ Mood } \\
\hline SDF & $\mathrm{L}^{*}$ & $\mathrm{~L}$ & $\mathrm{H}$ & $\mathrm{H}^{*}$ & $\mathrm{H}-\mathrm{L}$ & $\mathrm{H}^{*}-\mathrm{L}^{*}$ & $\mathrm{H}-\mathrm{L}$ & $\mathrm{H}^{*}-\mathrm{L}^{*}$ & $\mathrm{H}-\mathrm{L}$ & $\mathrm{H}^{*}-\mathrm{L}^{*}$ \\
\hline $\begin{array}{l}\text { IU1 } \\
\text { (Low) }\end{array}$ & -0.125 & -0.046 & 0.045 & 0.077 & $\begin{array}{l}.091^{* * *} \\
(5.06)\end{array}$ & $\begin{array}{l}.202^{* * * *} \\
(5.00)\end{array}$ & {$[6.11]^{* * *}$} & {$[6.75]^{* * *}$} & - & 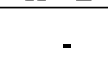 \\
\hline $\begin{array}{l}\text { IU3 } \\
\text { (High) }\end{array}$ & -0.099 & -0.111 & 0.009 & 0.007 & $\begin{array}{l}.120^{* * *} \\
(5.12)\end{array}$ & $\begin{array}{l}.106^{*} \\
(1.92)\end{array}$ & {$[8.22]^{* * *}$} & {$[4.01]^{* * *}$} & - & - \\
\hline $\begin{array}{l}\text { IU3- } \\
\text { IU1 }\end{array}$ & .026 & $-.065^{* * *}$ & $-.036^{* *}$ & -.069 & & & & & & \\
\hline $\begin{array}{l}\text { t-test } \\
\text { MWW }\end{array}$ & $\begin{array}{l}(0.52) \\
{[-1.16]}\end{array}$ & $\begin{array}{l}(-2.95) \\
{[-7.39]^{* * *}}\end{array}$ & $\begin{array}{l}(-1.81) \\
{[-4.51]^{* * *}}\end{array}$ & $\begin{array}{c}(-1.61) \\
{[-2.78]^{* * *}}\end{array}$ & & & & & & \\
\hline$\underline{B .2}$ & \multicolumn{4}{|c|}{ F-rank (mean) portfolios, median returns } & \multicolumn{2}{|c|}{$t$-test } & \multicolumn{2}{|c|}{$M W W$} & \multicolumn{2}{|c|}{$\begin{array}{c}\text { F-rank strategy } \\
\text { returns, Mood }\end{array}$} \\
\hline SDF & $\mathrm{L}^{*}$ & $\mathrm{~L}$ & $\mathrm{H}$ & $\mathrm{H}^{*}$ & $\mathrm{H}-\mathrm{L}$ & $\mathrm{H}^{*}-\mathrm{L}^{*}$ & $\mathrm{H}-\mathrm{L}$ & $\mathrm{H}^{*}-\mathrm{L}^{*}$ & $\mathrm{H}-\mathrm{L}$ & $\mathrm{H}^{*}-\mathrm{L}^{*}$ \\
\hline $\begin{array}{c}\text { IU1 } \\
\text { (Low) }\end{array}$ & -0.200 & -0.074 & 0.013 & 0.008 & - & - & - & - & $\begin{array}{l}.087^{* * * *} \\
(17.19)\end{array}$ & $\begin{array}{l}.208^{* * *} \\
(39.62)\end{array}$ \\
\hline $\begin{array}{l}\text { IU3 } \\
\text { (High) }\end{array}$ & -0.240 & -0.230 & -0.062 & -0.092 & - & - & - & - & $\begin{array}{l}.168^{* * *} \\
(50.89)\end{array}$ & $\begin{array}{l}.149^{* * *} \\
(7.39)\end{array}$ \\
\hline $\begin{array}{c}\text { IU3- } \\
\text { IU1 } \\
\text { Mood }\end{array}$ & $\begin{array}{l}-.041 \\
(-1.34)\end{array}$ & $\begin{array}{l}-.156^{* * *} \\
(-56.73)\end{array}$ & $\begin{array}{l}-.075 * * * \\
(-21.29)\end{array}$ & $\begin{array}{l}-0.100^{* * *} \\
(-7.38)\end{array}$ & & & & & & \\
\hline
\end{tabular}

Notes: Panels A.1 and B.1 report the winsorised mean and panels A.2 and B.2 the winsorised median portfolio returns in relation to information uncertainty (SDF) where: IU3=high; IU1=low. Financial strength is measured by the F-Score and the F-rank. Portfolios are independently sorted on Financial strength and on IU, thus the order of sorting is irrelevant. The first section of columns contain portfolio returns. $\mathrm{L}^{*}$ is a portfolio which contains (approximately) the lowest $5 \%$ of firms by Financial strength. Portfolio L contains (approximately) the $20 \%$ of firms with low Financial strength. Portfolio H contains (approximately) the $20 \%$ of firms with high Financial strength. $\mathrm{H}^{*}$ is a portfolio which contains (approximately) the highest $5 \%$ of firms by Financial strength. In the remaining columns of the table the performance as financial strength strategy returns and associated tests are reported. H-L is a zero investment financial strength strategy return, which takes a long position in the high financial strength firms and a short position in low financial strength firms. T-test reported in parentheses are parametric unpaired two-sample t-tests. MWW is the Mann-Whitney-Wilcoxon non-parametric version of the ttest reported in brackets. The t-test and MWW test are only calculated when the mean strategy return is examined. Median tests reported in parentheses are based on Mood's (1950) non-parametric median test for two independent samples; thus the mood test is only calculated when the median strategy return is considered. These tests are applied to the Financial Strength strategy returns as well as to test for differences between IU portfolios holding financial strength constant (B-S). All returns are reported in decimals. 
Table 5. Two-way F-Score/MADF portfolios.

\begin{tabular}{|c|c|c|c|c|c|c|c|c|c|c|}
\hline \multirow{2}{*}{$\begin{array}{c}\underline{\mathbf{A . 1}} \\
\text { MADF }\end{array}$} & \multicolumn{4}{|c|}{ F-Score portfolios, mean returns } & \multicolumn{2}{|c|}{$\begin{array}{c}\text { F-Score strategy } \\
\text { returns, } t \text {-test }\end{array}$} & \multicolumn{2}{|c|}{$\begin{array}{c}\text { F-Score strategy } \\
\text { MWW test }\end{array}$} & \multicolumn{2}{|c|}{ Mood median } \\
\hline & $\mathrm{L}^{*}$ & $\mathrm{~L}$ & $\mathrm{H}$ & $\mathrm{H}^{*}$ & $\mathrm{H}-\mathrm{L}$ & $\mathrm{H}^{*}-\mathrm{L}^{*}$ & $\mathrm{H}-\mathrm{L}$ & $\mathrm{H}^{*}-\mathrm{L}^{*}$ & $\mathrm{H}-\mathrm{L}$ & $\mathrm{H}^{*}-\mathrm{L}^{*}$ \\
\hline $\begin{array}{c}\text { IU1 } \\
\text { (Low) }\end{array}$ & -0.159 & -0.081 & 0.063 & 0.069 & $\begin{array}{l}.144^{* * *} \\
(7.66)\end{array}$ & $\begin{array}{l}.228^{* * *} \\
(7.26)\end{array}$ & {$[9.78]^{* * *}$} & {$[8.51]^{* * *}$} & - & - \\
\hline $\begin{array}{c}\text { IU3 } \\
\text { (High) }\end{array}$ & -0.165 & -0.135 & 0.045 & 0.162 & $\begin{array}{l}.180^{* * *} \\
(6.57)\end{array}$ & $\begin{array}{l}.327^{* * *} \\
(4.98)\end{array}$ & {$[8.41]^{* * *}$} & {$[5.65] * * *$} & - & - \\
\hline $\begin{array}{l}\text { IU3- } \\
\text { IU1 }\end{array}$ & -.006 & $-.054 * *$ & -.018 & $.093 *$ & & & & & & \\
\hline $\begin{array}{l}\text { t-test } \\
\text { MWW }\end{array}$ & $\begin{array}{l}(-0.13) \\
{[-1.11]}\end{array}$ & $\begin{array}{l}(-2.24) \\
{[-4.10]^{* * *}}\end{array}$ & $\begin{array}{l}(-0.85) \\
{[-3.21]^{* * *}}\end{array}$ & $\begin{array}{l}(1.96) \\
{[0.74]}\end{array}$ & & & & & & \\
\hline$\underline{\mathrm{A.2}}$ & \multicolumn{4}{|c|}{ F-Score portfolios, median returns } & \multicolumn{2}{|c|}{ t-test } & \multicolumn{2}{|c|}{$M W W$} & \multicolumn{2}{|c|}{$\begin{array}{c}\text { F-Score strategy } \\
\text { returns, Mood }\end{array}$} \\
\hline MADF & $\mathrm{L}^{*}$ & $\mathrm{~L}$ & $\mathrm{H}$ & $\mathrm{H}^{*}$ & $\mathrm{H}-\mathrm{L}$ & $\mathrm{H}^{*}-\mathrm{L}^{*}$ & $\mathrm{H}-\mathrm{L}$ & $\mathrm{H}^{*}-\mathrm{L}^{*}$ & $\mathrm{H}-\mathrm{L}$ & $\mathrm{H}^{*}-\mathrm{L}^{*}$ \\
\hline $\begin{array}{c}\text { IU1 } \\
\text { (Low) }\end{array}$ & -0.207 & -0.147 & 0.026 & 0.013 & - & - & - & - & $\begin{array}{l}.173 * * * \\
(57.24)\end{array}$ & $\begin{array}{l}.220^{* * *} \\
(44.37)\end{array}$ \\
\hline $\begin{array}{c}\text { IU3 } \\
\text { (High) }\end{array}$ & -0.262 & -0.228 & -0.044 & 0.069 & - & - & - & - & $\begin{array}{l}.184 * * * \\
(40.24)\end{array}$ & $\begin{array}{l}.331^{* * *} \\
(17.85)\end{array}$ \\
\hline $\begin{array}{l}\text { IU3- } \\
\text { IU1 } \\
\text { Mood }\end{array}$ & $\begin{array}{l}-.055^{*} \\
(-3.45)\end{array}$ & $\begin{array}{l}-.081 * * * \\
(-20.29)\end{array}$ & $\begin{array}{l}-.070 * * * \\
(-8.57)\end{array}$ & $\begin{array}{l}0.056 \\
(0.95)\end{array}$ & & & & & & \\
\hline$\underline{B .1}$ & \multicolumn{4}{|c|}{ F-rank (mean) portfolios, mean returns } & \multicolumn{2}{|c|}{$\begin{array}{c}\text { F-rank strategy } \\
\text { returns, } t \text {-test }\end{array}$} & \multicolumn{2}{|c|}{$\begin{array}{c}F-\text { rank strategy } \\
M W W \text { test }\end{array}$} & \multicolumn{2}{|c|}{ Mood median } \\
\hline MADF & $\mathrm{L}^{*}$ & $\mathrm{~L}$ & $\mathrm{H}$ & $\mathrm{H}^{*}$ & $\mathrm{H}-\mathrm{L}$ & $\mathrm{H}^{*}-\mathrm{L}^{*}$ & $\mathrm{H}-\mathrm{L}$ & $\mathrm{H}^{*}-\mathrm{L}^{*}$ & $\mathrm{H}-\mathrm{L}$ & $\mathrm{H}^{*}-\mathrm{L}^{*}$ \\
\hline $\begin{array}{c}\text { IU1 } \\
\text { (Low) }\end{array}$ & -0.136 & -0.063 & 0.048 & 0.066 & $\begin{array}{l}.111^{* * * *} \\
(5.92)\end{array}$ & $\begin{array}{l}.202^{* * *} \\
(5.19)\end{array}$ & {$[7.35]^{* * *}$} & {$[7.39] * * *$} & - & - \\
\hline $\begin{array}{c}\text { IU3 } \\
\text { (High) }\end{array}$ & -0.117 & -0.115 & 0.017 & 0.009 & & $\begin{array}{l}.126^{*} \\
(1.93)\end{array}$ & {$[8.32]^{* * *}$} & {$[3.77]^{* * *}$} & - & - \\
\hline $\begin{array}{l}I U 3- \\
I U 1\end{array}$ & .019 & $-.052^{* *}$ & -.031 & -.057 & & & & & & \\
\hline $\begin{array}{l}\text { t-test } \\
\text { MWW }\end{array}$ & $\begin{array}{l}(0.36) \\
{[-1.06]}\end{array}$ & $\begin{array}{c}(-2.35) \\
{[-6.10] * * *}\end{array}$ & $\begin{array}{l}(-1.53) \\
{[-4.28]^{* * *}}\end{array}$ & $\begin{array}{l}(-1.26) \\
{[-2.50]^{* *}}\end{array}$ & & & & & & \\
\hline$\underline{B .2}$ & \multicolumn{4}{|c|}{$F$-rank (mean), median returns } & \multicolumn{2}{|c|}{ t-test } & \multicolumn{2}{|c|}{$M W W$} & \multicolumn{2}{|c|}{$\begin{array}{c}\text { F-rank strategy } \\
\text { returns, } \text { Mood }\end{array}$} \\
\hline MADF & $\mathrm{L}^{*}$ & $\mathrm{~L}$ & $\mathrm{H}$ & $\mathrm{H}^{*}$ & $\mathrm{H}-\mathrm{L}$ & $\mathrm{H}^{*-\mathrm{L}^{*}}$ & $\mathrm{H}-\mathrm{L}$ & $\mathrm{H}^{*}-\mathrm{L}^{*}$ & $\mathrm{H}-\mathrm{L}$ & $\mathrm{H}^{*}-\mathrm{L}^{*}$ \\
\hline $\begin{array}{c}\text { IU1 } \\
\text { (Low) }\end{array}$ & -0.210 & -0.101 & 0.013 & 0.006 & - & & - & - & $\begin{array}{l}114^{* * *} \\
(34.47)\end{array}$ & $\begin{array}{l}.216^{* * *} \\
(43.30)\end{array}$ \\
\hline $\begin{array}{l}\text { IU3 } \\
\text { (High) }\end{array}$ & -0.252 & -0.230 & -0.060 & -0.095 & - & & . & - & $\begin{array}{l}.170^{* * * *} \\
(46.02)\end{array}$ & $\begin{array}{l}.157^{* *} \\
(5.22)\end{array}$ \\
\hline $\begin{array}{c}\text { IU3- } \\
\text { IU1 } \\
\text { Mood }\end{array}$ & $\begin{array}{l}-.041 \\
(-1.27)\end{array}$ & $\begin{array}{l}-.129 * * * \\
(-43.83)\end{array}$ & $\begin{array}{l}-.073 * * * \\
(-20.00)\end{array}$ & $\begin{array}{l}-0.101^{* *} \\
(-4.30)\end{array}$ & & & & & & \\
\hline
\end{tabular}

Notes: Panels A.1 and B.1 report the winsorised mean and panels A.2 and B.2 the winsorised median portfolio returns in relation to information uncertainty (MADF) where: IU3=high; IU1=low. F. Financial strength is measured by the F-Score and the F-rank. Portfolios are independently sorted on Financial strength and on IU, thus the order of sorting is irrelevant. The first section of columns contain portfolio returns. $\mathrm{L}^{*}$ is a portfolio which contains (approximately) the lowest $5 \%$ of firms by Financial strength. Portfolio L contains (approximately) the $20 \%$ of firms with low Financial strength. Portfolio H contains (approximately) the $20 \%$ of firms with high Financial strength. $\mathrm{H}^{*}$ is a portfolio which contains (approximately) the highest $5 \%$ of firms by Financial strength. In the remaining columns of the table the performance as financial strength strategy returns and associated tests are reported. H-L is a zero investment financial strength strategy return, which takes a long position in the high financial strength firms and a short position in low financial strength firms. T-test reported in parentheses are parametric unpaired two-sample t-tests. MWW is the Mann-Whitney-Wilcoxon non-parametric version of the ttest reported in brackets. The t-test and MWW test are only calculated when the mean strategy return is examined. Median tests reported in parentheses are based on Mood's (1950) non-parametric median test for two independent samples; thus the mood test is only calculated when the median strategy return is considered. These tests are applied to the Financial Strength strategy returns as well as to test for differences between IU portfolios holding financial strength constant (B-S). All returns are reported in decimals. 
Table 6. Two-way F-Score/Amihud portfolios.

\begin{tabular}{|c|c|c|c|c|c|c|c|c|c|c|}
\hline$\underline{\mathbf{A} .1}$ & \multicolumn{4}{|c|}{ F-Score portfolios, mean returns } & \multicolumn{2}{|c|}{$\begin{array}{c}\text { F-Score strategy } \\
\text { returns, } t \text {-test }\end{array}$} & \multicolumn{2}{|c|}{$\begin{array}{c}\text { F-Score strategy } \\
\text { MWW test }\end{array}$} & \multicolumn{2}{|c|}{ Mood median } \\
\hline AMI & $\mathrm{L}^{*}$ & $\mathrm{~L}$ & $\mathrm{H}$ & $\mathrm{H}^{*}$ & $\mathrm{H}-\mathrm{L}$ & $\mathrm{H}^{*}-\mathrm{L}^{*}$ & $\mathrm{H}-\mathrm{L}$ & $\mathrm{H}^{*}-\mathrm{L}^{*}$ & $\mathrm{H}-\mathrm{L}$ & $\mathrm{H}^{*}-\mathrm{L}^{*}$ \\
\hline $\begin{array}{c}\text { LQ1 } \\
\text { (Illiquid) }\end{array}$ & -0.125 & -0.117 & 0.054 & 0.098 & $\begin{array}{l}.171^{* * *} \\
(8.70)\end{array}$ & $\begin{array}{l}.223 * * * \\
(6.39)\end{array}$ & {$[12.53]^{* * *}$} & {$[9.15]^{* * *}$} & - & - \\
\hline $\begin{array}{c}\text { LQ3 } \\
\text { (Liquid) }\end{array}$ & -0.117 & -0.072 & 0.052 & 0.039 & $\begin{array}{l}.124 * * * \\
(6.01)\end{array}$ & $\begin{array}{l}.156^{* * *} \\
(3.72)\end{array}$ & {$[7.30]^{* * *}$} & {$[4.72] * * *$} & - & - \\
\hline $\begin{array}{l}\text { LQ3- } \\
\text { LQ1 }\end{array}$ & .008 & $.045^{*}$ & -.002 & -.059 & & & & & & \\
\hline $\begin{array}{l}\text { t-test } \\
\text { MWW }\end{array}$ & $\begin{array}{l}(0.16) \\
{[1.54]}\end{array}$ & $\begin{array}{l}(1.70) \\
{[4.44]^{* * *}}\end{array}$ & $\begin{array}{l}(-0.12) \\
{[2.94]^{* * *}}\end{array}$ & $\begin{array}{l}(-1.59) \\
{[0.24]}\end{array}$ & & & & & & \\
\hline$\underline{\mathrm{A.2}}$ & \multicolumn{4}{|c|}{ F-Score portfolios, median returns } & \multicolumn{2}{|c|}{ t-test } & \multicolumn{2}{|c|}{$M W W$} & \multicolumn{2}{|c|}{$\begin{array}{c}\text { F-Score strategy } \\
\text { returns, Mood }\end{array}$} \\
\hline AMI & $\mathrm{L}^{*}$ & $\mathrm{~L}$ & $\mathrm{H}$ & $\mathrm{H}^{*}$ & $\mathrm{H}-\mathrm{L}$ & $\mathrm{H}^{*}-\mathrm{L}^{*}$ & $\mathrm{H}-\mathrm{L}$ & $\mathrm{H}^{*}-\mathrm{L}^{*}$ & $\mathrm{H}-\mathrm{L}$ & $\mathrm{H}^{*}-\mathrm{L}^{*}$ \\
\hline $\begin{array}{c}\text { LQ1 } \\
\text { (Illiquid) }\end{array}$ & -0.230 & -0.213 & -0.017 & 0.009 & - & - & - & - & $\begin{array}{l}.196 * * * \\
(137.57)\end{array}$ & $\begin{array}{l}.239 * * * \\
(73.75)\end{array}$ \\
\hline $\begin{array}{c}\text { LQ3 } \\
\text { (Liquid) }\end{array}$ & -0.170 & -0.096 & 0.044 & 0.036 & - & - & - & - & $\begin{array}{l}.140^{* * *} \\
(31.54)\end{array}$ & $\begin{array}{l}.206^{* * *} \\
(13.96)\end{array}$ \\
\hline $\begin{array}{l}L Q 3- \\
L Q 1 \\
\end{array}$ & $\begin{array}{l}.060 \\
(1.76) \\
\end{array}$ & $\begin{array}{l}.117^{* * *} \\
(23.88) \\
\end{array}$ & $\begin{array}{l}.061 * * * \\
(9.79)\end{array}$ & $\begin{array}{l}.027 \\
(0.39) \\
\end{array}$ & & & & & & \\
\hline$\underline{\text { B.1 }}$ & \multicolumn{4}{|c|}{ F-rank (mean) portfolios, mean returns } & \multicolumn{2}{|c|}{$\begin{array}{c}\text { F-rank strategy } \\
\text { returns, } t \text {-test }\end{array}$} & \multicolumn{2}{|c|}{$\begin{array}{c}F-\text { rank strategy } \\
M W W \text { test }\end{array}$} & \multicolumn{2}{|c|}{ Mood median } \\
\hline AMI & $\mathrm{L}^{*}$ & $\mathrm{~L}$ & $\mathrm{H}$ & $\mathrm{H}^{*}$ & $\mathrm{H}-\mathrm{L}$ & $\mathrm{H}^{*}-\mathrm{L}^{*}$ & $\mathrm{H}-\mathrm{L}$ & $\mathrm{H}^{*}-\mathrm{L}^{*}$ & $\mathrm{H}-\mathrm{L}$ & $\mathrm{H}^{*}-\mathrm{L}^{*}$ \\
\hline $\begin{array}{c}\text { LQ1 } \\
\text { (Illiquid) }\end{array}$ & -0.112 & -0.098 & 0.038 & 0.064 & $\begin{array}{l}.136^{* * *} \\
(7.12)\end{array}$ & $\begin{array}{l}.176^{* * *} \\
(4.52)\end{array}$ & {$[11.05]^{* * *}$} & {$[7.83]^{* * *}$} & - & - \\
\hline $\begin{array}{c}\text { LQ3 } \\
\text { (Liquid) }\end{array}$ & -0.134 & -0.041 & 0.041 & 0.039 & $\begin{array}{l}.082 * * * \\
(3.92)\end{array}$ & $\begin{array}{l}.173^{* * *} \\
(3.11)\end{array}$ & {$[4.63]^{* * *}$} & {$[3.99]^{* * *}$} & - & - \\
\hline $\begin{array}{l}\text { LQ3- } \\
\text { LQ1 }\end{array}$ & -.022 & $.060 * * *$ & .003 & -.025 & & & & & & \\
\hline $\begin{array}{l}\text { t-test } \\
\text { MWW }\end{array}$ & $\begin{array}{l}(-0.37) \\
{[0.79]}\end{array}$ & $\begin{array}{l}(2.52) \\
{[6.88]^{* * *}}\end{array}$ & $\begin{array}{l}(0.13) \\
{[2.82]^{* * *}}\end{array}$ & $\begin{array}{l}(-0.54) \\
{[0.06]}\end{array}$ & & & & & & \\
\hline$\underline{\text { B.2 }}$ & \multicolumn{4}{|c|}{ F-rank (mean), median returns } & \multicolumn{2}{|c|}{ t-test } & \multicolumn{2}{|c|}{$M W W$} & \multicolumn{2}{|c|}{$\begin{array}{c}\text { F-rank strategy } \\
\text { returns, Mood }\end{array}$} \\
\hline AMI & $\mathrm{L}^{*}$ & $\mathrm{~L}$ & $\mathrm{H}$ & $\mathrm{H}^{*}$ & $\mathrm{H}-\mathrm{L}$ & $\mathrm{H}^{*}-\mathrm{L}^{*}$ & $\mathrm{H}-\mathrm{L}$ & $\mathrm{H}^{*}-\mathrm{L}^{*}$ & H-L & $\mathrm{H}^{*}-\mathrm{L}^{*}$ \\
\hline $\begin{array}{c}\text { LQ1 } \\
\text { (Illiquid) }\end{array}$ & -0.230 & -0.207 & -0.035 & -0.010 & - & & - & - & $\begin{array}{l}.172 * * * \\
(99.15)\end{array}$ & $\begin{array}{l}.219 * * * \\
(49.85)\end{array}$ \\
\hline $\begin{array}{c}\text { LQ3 } \\
\text { (Liquid) }\end{array}$ & -0.199 & -0.052 & -0.013 & -0.010 & - & - & - & - & $\begin{array}{l}.039 * * * \\
(10.77)\end{array}$ & $\begin{array}{l}.189^{* * *} \\
(11.29)\end{array}$ \\
\hline $\begin{array}{l}L Q 3- \\
L Q 1 \\
\end{array}$ & $\begin{array}{l}.031 \\
(0.33) \\
\end{array}$ & $\begin{array}{l}.155^{* * *} \\
(49.20) \\
\end{array}$ & $\begin{array}{l}.022^{* * *} \\
(10.12) \\
\end{array}$ & $\begin{array}{l}.000 \\
(0.24) \\
\end{array}$ & & & & & & \\
\hline
\end{tabular}

Notes: Panels A.1 and B.1 report the winsorised mean and panels A.2 and B.2 the winsorised median portfolio returns in relation to liquidity (AMI (Amihud, 2002)) where: LQ1=illiquid; LQ3=liquid. Financial strength is measured by the F-Score and the F-rank. Portfolios are independently sorted on Financial strength and on Liquidity, thus the order of sorting is irrelevant. The first section of columns contain portfolio returns. $\mathrm{L}^{*}$ is a portfolio which contains (approximately) the lowest $5 \%$ of firms by Financial strength. Portfolio L contains (approximately) the $20 \%$ of firms with low Financial strength. Portfolio H contains (approximately) the $20 \%$ of firms with high Financial strength. $\mathrm{H}^{*}$ is a portfolio which contains (approximately) the highest $5 \%$ of firms by Financial strength. In the remaining columns of the table the performance as financial strength strategy returns and associated tests are reported. H-L is a zero investment financial strength strategy return, which takes a long position in the high financial strength firms and a short position in low financial strength firms. T-test reported in parentheses are parametric unpaired two-sample t-tests. MWW is the Mann-Whitney-Wilcoxon non-parametric version of the t-test reported in brackets. The t-test and MWW test are only calculated when the mean strategy return is examined. Median tests reported in parentheses are based on Mood's (1950) non-parametric median test for two independent samples; thus the mood test is only calculated when the median strategy return is considered. These tests are applied to the Financial Strength strategy returns as well as to test for differences between IU portfolios holding financial strength constant (B-S). All returns are reported in decimals. 
Table 7. Two-way F-Score/ToR portfolios.

\begin{tabular}{|c|c|c|c|c|c|c|c|c|c|c|}
\hline$\underline{\text { A.1 }}$ & \multicolumn{4}{|c|}{ F-Score portfolios, mean returns } & \multicolumn{2}{|c|}{$\begin{array}{c}\text { F-Score strategy } \\
\text { returns, t-test }\end{array}$} & \multicolumn{2}{|c|}{$\begin{array}{c}\text { F-Score strategy } \\
\text { MWW test }\end{array}$} & \multicolumn{2}{|c|}{ Mood } \\
\hline ToR & $\mathrm{L}^{*}$ & $\mathrm{~L}$ & $\mathrm{H}$ & $\mathrm{H}^{*}$ & $\mathrm{H}-\mathrm{L}$ & $\mathrm{H}^{*}-\mathrm{L}^{*}$ & $\mathrm{H}-\mathrm{L}$ & $\mathrm{H}^{*}-\mathrm{L}^{*}$ & $\mathrm{H}-\mathrm{L}$ & $\mathrm{H}^{*}-\mathrm{L}^{*}$ \\
\hline $\begin{array}{c}\text { LQ1 } \\
\text { (Illiquid) }\end{array}$ & -0.214 & -0.165 & 0.050 & 0.074 & $\begin{array}{l}.215^{* * *} \\
(9.60)\end{array}$ & $\begin{array}{l}.288 * * * \\
(7.63)\end{array}$ & {$[12.62]^{* * *}$} & {$[9.69]^{* * *}$} & - & - \\
\hline $\begin{array}{c}\text { LQ3 } \\
\text { (Liquid) }\end{array}$ & -0.096 & -0.068 & 0.048 & 0.070 & $\begin{array}{l}.116^{* * *} \\
(6.05)\end{array}$ & $\begin{array}{l}.166^{* * *} \\
(4.48)\end{array}$ & {$[9.10]^{* * *}$} & {$[6.16]^{* * *}$} & - & - \\
\hline $\begin{array}{l}L Q 3- \\
L Q 1\end{array}$ & $.118^{* * *}$ & $.097 * * *$ & -.002 & -.004 & & & & & & \\
\hline $\begin{array}{c}\text { t-test } \\
\text { MWW }\end{array}$ & $\begin{array}{l}(2.77) \\
{[3.46]^{* * *}}\end{array}$ & $\begin{array}{l}(4.03) \\
{[5.23]^{* * *}}\end{array}$ & $\begin{array}{l}(-0.15) \\
{[0.99]}\end{array}$ & $\begin{array}{l}(-0.12) \\
{[0.56]}\end{array}$ & & & & & & \\
\hline$\underline{\mathbf{A . 2}}$ & \multicolumn{4}{|c|}{ F-Score portfolios, median returns } & \multicolumn{2}{|c|}{ t-test } & \multicolumn{2}{|c|}{$M W W$} & \multicolumn{2}{|c|}{$\begin{array}{c}\text { F-Score strategy } \\
\text { returns, Mood }\end{array}$} \\
\hline ToR & $\mathrm{L}^{*}$ & $\mathrm{~L}$ & $\mathrm{H}$ & $\mathrm{H}^{*}$ & $\mathrm{H}-\mathrm{L}$ & $\mathrm{H}^{*}-\mathrm{L}^{*}$ & $\mathrm{H}-\mathrm{L}$ & $\mathrm{H}^{*}-\mathrm{L}^{*}$ & $\mathrm{H}-\mathrm{L}$ & $\mathrm{H}^{*}-\mathrm{L}^{*}$ \\
\hline $\begin{array}{c}\text { LQ1 } \\
\text { (Illiquid) }\end{array}$ & -0.267 & -0.230 & -0.019 & -0.010 & - & - & - & - & $\begin{array}{l}.211 * * * \\
(128.48)\end{array}$ & $\begin{array}{l}.257 * * * \\
(71.62)\end{array}$ \\
\hline $\begin{array}{c}\text { LQ3 } \\
\text { (Liquid) }\end{array}$ & -0.176 & -0.132 & 0.013 & 0.027 & - & - & - & - & $\begin{array}{l}.145^{* * *} \\
(60.23)\end{array}$ & $\begin{array}{l}.203 * * * \\
(26.66)\end{array}$ \\
\hline $\begin{array}{c}L Q 3- \\
L Q 1 \\
\end{array}$ & $\begin{array}{l}.091 * * * \\
(7.34) \\
\end{array}$ & $\begin{array}{l}.098 * * * \\
(22.09)\end{array}$ & $\begin{array}{l}.032^{*} \\
(2.85) \\
\end{array}$ & $\begin{array}{l}.037 \\
(2.47)\end{array}$ & & & & & & \\
\hline$\underline{\text { B.1 }}$ & \multicolumn{4}{|c|}{ F-rank (mean) portfolios, mean returns } & \multicolumn{2}{|c|}{$\begin{array}{c}\text { F-rank strategy } \\
\text { returns, } t \text {-test }\end{array}$} & \multicolumn{2}{|c|}{$\begin{array}{c}F-\text { rank strategy } \\
\text { MWW test }\end{array}$} & \multicolumn{2}{|c|}{ Mood } \\
\hline ToR & $\mathrm{L}^{*}$ & $\mathrm{~L}$ & $\mathrm{H}$ & $\mathrm{H}^{*}$ & H-L & $\mathrm{H}^{*}-\mathrm{L}^{*}$ & $\mathrm{H}-\mathrm{L}$ & $\mathrm{H}^{*}-\mathrm{L}^{*}$ & $\mathrm{H}-\mathrm{L}$ & $\mathrm{H}^{*}-\mathrm{L}^{*}$ \\
\hline $\begin{array}{c}\text { LQ1 } \\
\text { (Illiquid) }\end{array}$ & -0.216 & -0.168 & 0.025 & 0.043 & $\begin{array}{l}.194^{* * *} \\
(8.99)\end{array}$ & $\begin{array}{l}.259 * * * \\
(5.89)\end{array}$ & {$[12.36]^{* * *}$} & {$[9.58] * * *$} & - & - \\
\hline $\begin{array}{c}\text { LQ3 } \\
\text { (Liquid) }\end{array}$ & -0.085 & -0.033 & 0.039 & 0.036 & $\begin{array}{l}.071^{* * *} \\
(3.80)\end{array}$ & $\begin{array}{l}.121^{* * *} \\
(2.92)\end{array}$ & {$[5.65]^{* * *}$} & {$[4.84]^{* * *}$} & - & - \\
\hline $\begin{array}{l}L Q 3- \\
L Q 1\end{array}$ & $.130^{* * *}$ & $.136^{* * *}$ & .013 & -.006 & & & & & & \\
\hline $\begin{array}{l}\text { t-test } \\
\text { MWW }\end{array}$ & $\begin{array}{l}(2.76) \\
{[4.37]^{* * *}}\end{array}$ & $\begin{array}{l}(6.31) \\
{[8.25]^{* * *}}\end{array}$ & $\begin{array}{l}(0.72) \\
{[1.06]}\end{array}$ & $\begin{array}{l}(-0.17) \\
{[-1.08]}\end{array}$ & & & & & & \\
\hline$\underline{\text { B.2 }}$ & \multicolumn{4}{|c|}{$F$-rank (mean), median returns } & & & \multicolumn{2}{|c|}{$M W W$} & \multicolumn{2}{|c|}{$\begin{array}{c}\text { F-rank strategy } \\
\text { returns, Mood }\end{array}$} \\
\hline ToR & $\mathrm{L}^{*}$ & $\mathrm{~L}$ & $\mathrm{H}$ & $\mathrm{H}^{*}$ & $\mathrm{H}-\mathrm{L}$ & $\mathrm{H}^{*}-\mathrm{L}^{*}$ & $\mathrm{H}-\mathrm{L}$ & $\mathrm{H}^{*}-\mathrm{L}^{*}$ & $\mathrm{H}-\mathrm{L}$ & $\mathrm{H}^{*}-\mathrm{L}^{*}$ \\
\hline $\begin{array}{c}\text { LQ1 } \\
\text { (Illiquid) }\end{array}$ & -0.343 & -0.237 & -0.038 & 0.008 & - & & - & - & $\begin{array}{l}.199^{* * *} \\
(122.48)\end{array}$ & $\begin{array}{l}.351 * * * \\
(88.42)\end{array}$ \\
\hline $\begin{array}{c}\text { LQ3 } \\
\text { (Liquid) }\end{array}$ & -0.191 & -0.099 & -0.010 & -0.020 & - & - & - & - & $\begin{array}{l}.088^{* * *} \\
(24.12)\end{array}$ & $\begin{array}{l}.171 * * * \\
(16.21)\end{array}$ \\
\hline $\begin{array}{l}L Q 3- \\
L Q 1 \\
\end{array}$ & $\begin{array}{l}.152^{* * *} \\
(12.14) \\
\end{array}$ & $\begin{array}{l}.138^{* * *} \\
(63.09) \\
\end{array}$ & $\begin{array}{l}.028^{* *} \\
(5.37) \\
\end{array}$ & $\begin{array}{l}-.028 \\
(-0.45) \\
\end{array}$ & & & & & & \\
\hline
\end{tabular}

Notes: Panels A.1 and B.1 report the winsorised mean and panels A.2 and B.2 the winsorised median portfolio returns in relation to liquidity (ToR) where: LQ1=illiquid; LQ3=liquid. Financial strength is measured by the FScore and the F-rank. Portfolios are independently sorted on Financial strength and then Liquidity. The first section of columns contain portfolio returns. $\mathrm{L}^{*}$ is a portfolio which contains (approximately) the lowest $5 \%$ of firms by Financial strength. Portfolio L contains (approximately) the $20 \%$ of firms with low Financial strength. Portfolio H contains (approximately) the $20 \%$ of firms with high Financial strength. $\mathrm{H}^{*}$ is a portfolio which contains (approximately) the highest $5 \%$ of firms by Financial strength. In the remaining columns of the table the performance as financial strength strategy returns and associated tests are reported. H-L is a zero investment financial strength strategy return, which takes a long position in the high financial strength firms and a short position in low financial strength firms. T-test reported in parentheses are parametric unpaired two-sample t-tests. MWW is the Mann-Whitney-Wilcoxon non-parametric version of the t-test reported in brackets. The t-test and MWW test are only calculated when the mean strategy return is examined. Median tests reported in parentheses are based on Mood's (1950) non-parametric median test for two independent samples; thus the mood test is only calculated when the median strategy return is considered. These tests are applied to the Financial Strength strategy returns as well as to test for differences between IU portfolios holding financial strength constant (B-S). All returns are reported in decimals. 
Table 8. Two-way F-Rank mean returns with alternative breakpoints (10-30).

\begin{tabular}{|c|c|c|c|c|c|c|c|c|c|c|}
\hline \multirow{2}{*}{$\begin{array}{l}\underline{\mathbf{A . 1}} \\
\mathrm{SDF}\end{array}$} & \multicolumn{4}{|c|}{$F-$ rank (mean), mean returns, $S D F$} & \multicolumn{2}{|c|}{$\begin{array}{c}\text { F-rank strategy } \\
\text { returns, } t \text {-test }\end{array}$} & \multicolumn{2}{|c|}{$\begin{array}{c}\text { F-rank strategy } \\
M W W \text { test }\end{array}$} & \multicolumn{2}{|c|}{ Mood } \\
\hline & $\mathrm{L}_{10}$ & $\mathrm{~L}_{30}$ & $\mathrm{H}_{30}$ & $\mathrm{H}_{10}$ & $\mathrm{H}_{30}-\mathrm{L}_{30}$ & $\mathrm{H}_{10}-\mathrm{L}_{10}$ & $\mathrm{H}_{30}-\mathrm{L}_{30}$ & $\mathrm{H}_{10}-\mathrm{L}_{10}$ & $\mathrm{H}_{30}-\mathrm{L}_{30}$ & $\mathrm{H}_{10}-\mathrm{L}_{10}$ \\
\hline $\begin{array}{l}\text { IU1 } \\
\text { (Low) }\end{array}$ & -0.087 & -0.020 & 0.045 & 0.051 & $\begin{array}{l}.065^{* * *} \\
(4.65)\end{array}$ & $\begin{array}{l}.138^{* * *} \\
(4.86)\end{array}$ & {$[5.09]^{* * *}$} & {$[6.55]^{* * *}$} & & \\
\hline $\begin{array}{l}\text { IU3 } \\
\text { (High) }\end{array}$ & -0.121 & -0.091 & 0.005 & 0.016 & $\begin{array}{l}.095^{* * * *} \\
(5.06)\end{array}$ & $\begin{array}{l}.137^{* * * *} \\
(3.79)\end{array}$ & {$[8.45]^{* * *}$} & {$[6.70]^{* * *}$} & - & - \\
\hline IU3- & .034 & $-.071^{* * *}$ & $-.041^{* *}$ & -.035 & & & & & & \\
\hline $\begin{array}{l}\text { t-test } \\
\text { MWW }\end{array}$ & $\begin{array}{l}(-0.99) \\
{[-3.10]^{* * *}}\end{array}$ & $\begin{array}{l}(-4.10) \\
{[-5.51]^{* * *}}\end{array}$ & $\begin{array}{c}(-2.53) \\
{[-9.66]^{* * *}}\end{array}$ & $\begin{array}{c}(-1.17) \\
{[-3.77]^{* * *}}\end{array}$ & & & & & & \\
\hline$\underline{\mathrm{A.2}}$ & \multicolumn{4}{|c|}{ F-rank (mean), mean returns, $M A D F$} & \multicolumn{2}{|c|}{$\begin{array}{c}\text { F-rank strategy } \\
\text { returns, } t \text {-test }\end{array}$} & \multicolumn{2}{|c|}{$\begin{array}{c}\text { F-rank strategy } \\
\text { MWW test }\end{array}$} & \multicolumn{2}{|c|}{ Mood } \\
\hline MADF & $\mathrm{L}_{10}$ & $\mathrm{~L}_{30}$ & $\mathrm{H}_{30}$ & $\mathrm{H}_{10}$ & $\mathrm{H}_{30}-\mathrm{L}_{30}$ & $\mathrm{H}_{10}-\mathrm{L}_{10}$ & $\mathrm{H}_{30}-\mathrm{L}_{30}$ & $\mathrm{H}_{10}-\mathrm{L}_{10}$ & $\mathrm{H}_{30}-\mathrm{L}_{30}$ & $\mathrm{H}_{10}-\mathrm{L}_{10}$ \\
\hline $\begin{array}{l}\text { IU1 } \\
\text { (Low) }\end{array}$ & -0.106 & -0.034 & 0.048 & 0.059 & $\begin{array}{l}.083^{* * *} \\
(5.70)\end{array}$ & $\begin{array}{l}.164^{* * *} \\
(5.89)\end{array}$ & ${ }_{* *}^{[6.43]^{*}}$ & {$[7.99]^{* * *}$} & - & $x_{0}$ \\
\hline $\begin{array}{l}\text { IU3 } \\
\text { (High) }\end{array}$ & -0.126 & -0.092 & 0.009 & 0.028 & $\begin{array}{r}.101^{* * *} \\
(5.33)\end{array}$ & $\begin{array}{l}.154^{*} \\
(3.95)\end{array}$ & $\underset{* *}{[8.52]^{*}}$ & {$[6.73]^{* * *}$} & - & - \\
\hline $\begin{array}{l}\text { IUS- } \\
\text { IUI }\end{array}$ & -.020 & $-.057^{* * *}$ & $-.039 * *$ & -.030 & & & & & & \\
\hline $\mathrm{t}$-test & $(-0.59)$ & $(-3.30)$ & $(-2.41)$ & $(-0.98)$ & & & & & & \\
\hline MWW & {$[-3.16]^{* * *}$} & {$[-5.32]^{* * *}$} & {$[-8.24]^{* * *}$} & {$[-3.18]^{* *}$} & & & & & & \\
\hline$\underline{\text { B.1 }}$ & \multicolumn{4}{|c|}{ F-rank (mean), mean returns, $A M I$} & \multicolumn{2}{|c|}{$\begin{array}{c}\text { F-rank strategy } \\
\text { returns, t-test }\end{array}$} & \multicolumn{2}{|c|}{$\begin{array}{c}\text { F-rank strategy } \\
M W W \text { test }\end{array}$} & \multicolumn{2}{|c|}{ Mood } \\
\hline AMI & $\mathrm{L}_{10}$ & $\mathrm{~L}_{30}$ & $\mathrm{H}_{30}$ & $\mathrm{H}_{10}$ & $\mathrm{H}_{30}-\mathrm{L}_{30}$ & $\mathrm{H}_{10}-\mathrm{L}_{10}$ & $\mathrm{H}_{30}-\mathrm{L}_{30}$ & $\mathrm{H}_{10}-\mathrm{L}_{10}$ & $\mathrm{H}_{30}-\mathrm{L}_{30}$ & $\mathrm{H}_{10}-\mathrm{L}_{10}$ \\
\hline $\begin{array}{l}\text { LQ1 } \\
\text { (Illiquid) }\end{array}$ & -0.114 & -0.075 & 0.036 & 0.040 & $\begin{array}{l}.111^{* * *} \\
(6.98)\end{array}$ & $\begin{array}{l}.154^{* * *} \\
(5.68)\end{array}$ & {$[11.21]^{* * *}$} & {$[9.35]^{* * *}$} & & - \\
\hline $\begin{array}{l}\text { LQ3 } \\
\text { (Liquid) }\end{array}$ & -0.088 & -0.015 & 0.031 & 0.050 & $\begin{array}{l}.046 * * * \\
(3.00)\end{array}$ & $\begin{array}{l}.138^{* * * *} \\
(3.80)\end{array}$ & {$[3.07]^{* * *}$} & {$[4.61]^{* * *}$} & - & - \\
\hline $\begin{array}{l}\text { LQ3- } \\
\text { LQ1 }\end{array}$ & .026 & $.060^{* * *}$ & -.005 & .010 & & & & & & \\
\hline $\begin{array}{l}\text { t-test } \\
\text { MWW }\end{array}$ & $\begin{array}{l}(0.71) \\
{\left[3.107^{* * *}\right.}\end{array}$ & $\begin{array}{l}(3.48) \\
{[9.29]^{* * *}}\end{array}$ & $\begin{array}{l}(-0.29) \\
{[2.57]^{* *}}\end{array}$ & $\begin{array}{l}(0.30) \\
{[1.687}\end{array}$ & & & & & & \\
\hline$\underline{\mathrm{A} .4}$ & \multicolumn{4}{|c|}{ F-rank (mean), mean returns, ToR } & \multicolumn{2}{|c|}{$\begin{array}{c}\text { F-rank strategy } \\
\text { returns, } t \text {-test }\end{array}$} & \multicolumn{2}{|c|}{$\begin{array}{c}\text { F-rank strategy } \\
M W W \text { test }\end{array}$} & \multirow{2}{*}{\multicolumn{2}{|c|}{$\begin{array}{c}\text { Mood } \\
\mathrm{H}_{30}-\mathrm{L}_{30} \quad \mathrm{H}_{10}-\mathrm{L}_{10}\end{array}$}} \\
\hline ToR & $\mathrm{L}_{10}$ & $\mathrm{H}_{30}-\mathrm{L}_{30}$ & $\mathrm{H}_{10}-\mathrm{L}_{10}$ & $\mathrm{H}_{30}-\mathrm{L}_{30}$ & $\mathrm{H}_{30}-\mathrm{L}_{30}$ & $\mathrm{H}_{10}-\mathrm{L}_{10}$ & $\mathrm{H}_{30}-\mathrm{L}_{30}$ & $\mathrm{H}_{10}-\mathrm{L}_{10}$ & & \\
\hline $\begin{array}{l}\text { LQ1 } \\
\text { (Illiquid) }\end{array}$ & -0.205 & -0.131 & 0.014 & 0.042 & $\begin{array}{r}.146 * * * \\
(8.17)\end{array}$ & $\begin{array}{r}.247^{* * * *} \\
(8.06)\end{array}$ & {$[11.77]^{* *}$} & {$[11.76]^{* * *}$} & - & - \\
\hline $\begin{array}{c}\text { LQ3 } \\
\text { (Liquid) }\end{array}$ & -0.049 & -0.012 & 0.043 & 0.029 & $\begin{array}{r}.054^{* * * *} \\
(3.67)\end{array}$ & $\begin{array}{r}.078^{* * *} \\
(2.67)\end{array}$ & & {$[4.93]^{* * *}$} & - & - \\
\hline $\begin{array}{l}\text { LQ3- } \\
\text { LQ1 }\end{array}$ & $.124^{* * *}$ & $.120^{* * *}$ & $.028^{*}$ & -.013 & & & & & & \\
\hline $\begin{array}{l}\text { t-test } \\
\text { MWW }\end{array}$ & $\begin{array}{l}(4.72) \\
{[6.12]^{* * *}}\end{array}$ & $\begin{array}{l}(6.94) \\
{\left[9.737^{* * *}\right.}\end{array}$ & $\begin{array}{l}(1.86) \\
{[2.30]^{* *}}\end{array}$ & $\begin{array}{l}(-0.48) \\
{[-1.37]}\end{array}$ & & & & & & \\
\hline
\end{tabular}

Notes: This Table follows a similar format to Panel B.1 of Tables 4-7. The winsorized mean is reported for Financial strength measured by the F-rank using alternative breakpoints of $10 \%$ and $30 \%$. Portfolios are independently sorted on Financial strength and then on either IU or Liquidity. The first section of columns contain portfolio returns. $\mathrm{L}_{10}$ is a portfolio which contains the lowest $10 \%$ of firms by Financial strength. Portfolio $\mathrm{L}_{30}$ contains the $30 \%$ of firms with low Financial strength. Portfolio $\mathrm{H}_{30}$ contains the top $30 \%$ of firms with high Financial strength. $\mathrm{H}_{10}$ is a portfolio which contains the highest $10 \%$ of firms by Financial strength. In the remaining columns of the table the performance as financial strength strategy returns and associated tests are reported. All returns are reported in decimals. Full details are provided in the notes to Tables 4-7. 
Table 9. Two-way F-Score industry-adjusted returns

\begin{tabular}{|c|c|c|c|c|c|c|c|c|c|c|}
\hline \multirow{2}{*}{$\begin{array}{l}\underline{\text { A.1a }} \\
\text { SDF }\end{array}$} & \multicolumn{4}{|c|}{ F-Score portfolios, mean IA returns } & \multicolumn{2}{|c|}{$\begin{array}{c}\text { F-Score strategy } \\
\text { returns, } t \text {-test }\end{array}$} & \multicolumn{2}{|c|}{$\begin{array}{c}\text { F-Score strategy } \\
\text { MWW test }\end{array}$} & \multicolumn{2}{|c|}{ Mood } \\
\hline & $\mathrm{L}^{*}$ & $\mathrm{~L}$ & $\mathrm{H}$ & $\mathrm{H}^{*}$ & H-L & $\mathrm{H}^{*}-\mathrm{L}^{*}$ & $\mathrm{H}-\mathrm{L}$ & $\mathrm{H}^{*}-\mathrm{L}^{*}$ & $\mathrm{H}-\mathrm{L}$ & $\mathrm{H}^{*}-\mathrm{L}^{*}$ \\
\hline $\begin{array}{c}\text { IU1 } \\
\text { (Low) }\end{array}$ & -0.108 & -0.056 & 0.049 & 0.054 & $\begin{array}{l}.105^{* * *} \\
(5.76)\end{array}$ & $\begin{array}{l}.162^{* * *} \\
(5.10)\end{array}$ & {$[7.56]^{* * *}$} & {$[6.63] * * *$} & - & - \\
\hline $\begin{array}{l}\text { IU3 } \\
\text { (High) }\end{array}$ & -0.143 & -0.120 & 0.029 & 0.085 & $\begin{array}{l}.149^{* * *} \\
(5.72)\end{array}$ & $\begin{array}{l}.228^{* * *} \\
(3.93)\end{array}$ & {$[7.82]^{* * *}$} & {$[5.45]^{* * *}$} & - & - \\
\hline $\begin{array}{l}\text { IU3- } \\
\text { IU1 }\end{array}$ & -.035 & $-.064 * * *$ & -.021 & .031 & & & & & & \\
\hline $\begin{array}{l}\text { t-test } \\
\text { MWW }\end{array}$ & $\begin{array}{c}(-0.81) \\
{[-1.92]^{*}}\end{array}$ & $\begin{array}{c}(-2.70) \\
{[-4.72] * * *}\end{array}$ & $\begin{array}{l}(-1.05) \\
{[-2.89] * * *}\end{array}$ & $\begin{array}{r}(0.73) \\
{[0.53]} \\
\end{array}$ & & & & & & \\
\hline$\underline{\mathbf{A . 1 b}}$ & \multicolumn{4}{|c|}{ F-Score portfolios, median IA returns } & \multicolumn{2}{|c|}{ t-test } & \multicolumn{2}{|c|}{$M W W$} & \multicolumn{2}{|c|}{$\begin{array}{l}\text { F-Score strategy } \\
\text { returns, Mood }\end{array}$} \\
\hline SDF & $\mathrm{L}^{*}$ & $\mathrm{~L}$ & $\mathrm{H}$ & $\mathrm{H}^{*}$ & $\mathrm{H}-\mathrm{L}$ & $\mathrm{H}^{*}-\mathrm{L}^{*}$ & $\mathrm{H}-\mathrm{L}$ & $\mathrm{H}^{*}-\mathrm{L}^{*}$ & H-L & $\mathrm{H}^{*}-\mathrm{L}^{*}$ \\
\hline $\begin{array}{l}\text { IU1 } \\
\text { (Low) }\end{array}$ & -0.149 & -0.082 & 0.012 & -0.011 & - & - & - & - & $\begin{array}{l}.094 * * * \\
(29.58)\end{array}$ & $\begin{array}{l}.138^{* * *} \\
(16.84)\end{array}$ \\
\hline $\begin{array}{l}\text { IU3 } \\
\text { (High) }\end{array}$ & -0.260 & -0.217 & -0.039 & 0.030 & - & - & - & - & $\begin{array}{l}.178^{* * * *} \\
(51.24)\end{array}$ & $\begin{array}{l}.290^{* * *} \\
(35.38)\end{array}$ \\
\hline IU3- & $-.111 * * *$ & $-.135^{* * *}$ & $-.051^{* *}$ & 0.041 & & & & & & \\
\hline IU1 & $(-7.89)$ & $(-27.49)$ & $(-6.59)$ & $(0.70)$ & & & & & & \\
\hline$\underline{\text { A.2a }}$ & \multicolumn{4}{|c|}{ F-Score portfolios, mean IA returns } & \multicolumn{2}{|c|}{$\begin{array}{c}\text { F-Score strategy } \\
\text { returns, } t \text {-test }\end{array}$} & \multicolumn{2}{|c|}{$\begin{array}{c}\text { F-Score strategy } \\
\text { MWW test }\end{array}$} & \multicolumn{2}{|c|}{ Mood } \\
\hline MADF & $\mathrm{L}^{*}$ & $\mathrm{~L}$ & $\mathrm{H}$ & $\mathrm{H}^{*}$ & H-L & $\mathrm{H}^{*}-\mathrm{L}^{*}$ & $\mathrm{H}-\mathrm{L}$ & $\mathrm{H}^{*}-\mathrm{L}^{*}$ & $\mathrm{H}-\mathrm{L}$ & $\mathrm{H}^{*}-\mathrm{L}^{*}$ \\
\hline $\begin{array}{c}\text { IU1 } \\
\text { (Low) }\end{array}$ & -0.140 & -0.069 & 0.060 & 0.065 & $\begin{array}{l}.129^{* * *} \\
(7.14)\end{array}$ & $\begin{array}{l}.205^{* * *} \\
(6.73)\end{array}$ & {$[9.20]^{* * *}$} & {$[8.14]^{* * *}$} & - & - \\
\hline $\begin{array}{l}\text { IU3 } \\
\text { (High) }\end{array}$ & -0.166 & -0.123 & 0.038 & 0.132 & $\begin{array}{l}.161^{* * *} \\
(6.14)\end{array}$ & $\begin{array}{l}.298 * * * \\
(4.87)\end{array}$ & {$[8.00]^{* * *}$} & {$[5.71]^{* * *}$} & - & - \\
\hline $\begin{array}{l}\text { IU3- } \\
\text { IU1 }\end{array}$ & -.027 & $-.054^{* * *}$ & $-.023^{* *}$ & .067 & & & & & & \\
\hline $\begin{array}{c}\text { t-test } \\
\text { MWW }\end{array}$ & $\begin{array}{l}(-0.65) \\
{[-1.43]} \\
\end{array}$ & $\begin{array}{l}(-2.31) \\
{[-3.91] * * *}\end{array}$ & $\begin{array}{l}(-1.15) \\
{[-3.26] * * *}\end{array}$ & $\begin{array}{r}(1.46) \\
{[0.70]} \\
\end{array}$ & & & & & & \\
\hline$\underline{\mathbf{A} .2 \mathbf{b}}$ & \multicolumn{4}{|c|}{ F-Score portfolios, median IA returns } & \multicolumn{2}{|c|}{ t-test } & \multicolumn{2}{|c|}{$M W W$} & \multicolumn{2}{|c|}{$\begin{array}{c}\text { F-Score strategy } \\
\text { returns, Mood }\end{array}$} \\
\hline MADF & $\mathrm{L}^{*}$ & $\mathrm{~L}$ & $\mathrm{H}$ & $\mathrm{H}^{*}$ & $\mathrm{H}-\mathrm{L}$ & $\mathrm{H}^{*}-\mathrm{L}^{*}$ & $\mathrm{H}-\mathrm{L}$ & $\mathrm{H}^{*}-\mathrm{L}^{*}$ & $\mathrm{H}-\mathrm{L}$ & $\mathrm{H}^{*}-\mathrm{L}^{*}$ \\
\hline $\begin{array}{l}\text { IU1 } \\
\text { (Low) }\end{array}$ & -0.170 & -0.105 & 0.021 & 0.004 & - & - & - & - & $\begin{array}{l}.126^{* * *} \\
(49.08)\end{array}$ & $\begin{array}{l}.174^{* * *} \\
(29.07)\end{array}$ \\
\hline $\begin{array}{l}\text { IU3 } \\
\text { (High) }\end{array}$ & -0.271 & -0.217 & -0.047 & 0.055 & - & - & - & - & $\begin{array}{l}.170^{* * *} \\
(52.08)\end{array}$ & $\begin{array}{l}.326^{* * *} \\
(35.82)\end{array}$ \\
\hline $\begin{array}{c}\text { IU3- } \\
\text { IUI }\end{array}$ & $\begin{array}{l}-.101^{* *} \\
(-5.30)\end{array}$ & $\begin{array}{l}-.112^{* * *} \\
(-20.63)\end{array}$ & $\begin{array}{l}-.068^{* * *} \\
(-11.42)\end{array}$ & $\begin{array}{l}-0.051 \\
(-1.02) \\
\end{array}$ & & & & & & \\
\hline$\underline{\mathbf{A . 3 a}}$ & \multicolumn{4}{|c|}{ F-Score portfolios, mean IA returns } & \multicolumn{2}{|c|}{$\begin{array}{l}\text { F-Score strategy } \\
\text { returns, } t \text {-test }\end{array}$} & \multicolumn{2}{|c|}{$\begin{array}{c}\text { F-Score strategy } \\
\text { MWW test }\end{array}$} & \multicolumn{2}{|c|}{ Mood } \\
\hline AMI & $\mathrm{L}^{*}$ & $\mathrm{~L}$ & $\mathrm{H}$ & $\mathrm{H}^{*}$ & H-L & $\mathrm{H}^{*}-\mathrm{L}^{*}$ & $\mathrm{H}-\mathrm{L}$ & $\mathrm{H}^{*}-\mathrm{L}^{*}$ & $\mathrm{H}-\mathrm{L}$ & $\mathrm{H}^{*}-\mathrm{L}^{*}$ \\
\hline $\begin{array}{c}\text { LQ1 } \\
\text { (Illiquid) }\end{array}$ & -0.120 & -0.110 & 0.053 & 0.093 & $\begin{array}{l}.164 * * * \\
(8.60)\end{array}$ & $\begin{array}{l}.213^{* * *} \\
(6.34)\end{array}$ & {$[12.26]^{* * *}$} & {$[8.83]^{* * *}$} & - & - \\
\hline $\begin{array}{c}\text { LQ3 } \\
\text { (Liquid) }\end{array}$ & -0.098 & -0.055 & 0.042 & 0.023 & $\begin{array}{l}.097 * * * \\
(5.00)\end{array}$ & $\begin{array}{l}.121^{* * *} \\
(2.97)\end{array}$ & {$[6.09]^{* * *}$} & {$[4.31]^{* * *}$} & - & - \\
\hline $\begin{array}{l}L Q 3- \\
L Q 1\end{array}$ & -.022 & $-.056^{* *}$ & .011 & $.070^{*}$ & & & & & & \\
\hline $\begin{array}{l}\text { t-test } \\
\text { MWW }\end{array}$ & $\begin{array}{c}(-0.43) \\
{[-1.85]^{*}}\end{array}$ & $\begin{array}{l}(-2.15) \\
{[-5.18]^{* * *}}\end{array}$ & $\begin{array}{l}(0.63) \\
{[-2.49] * *}\end{array}$ & $\begin{array}{r}(1.94) \\
{[-0.12]}\end{array}$ & & & & & & \\
\hline$\underline{\mathbf{A} .3 \mathbf{b}}$ & \multicolumn{4}{|c|}{ F-Score portfolios, median IA returns } & \multicolumn{2}{|c|}{$t$-test } & \multicolumn{2}{|c|}{$M W W$} & \multicolumn{2}{|c|}{$\begin{array}{c}\text { F-Score strategy } \\
\text { returns, Mood }\end{array}$} \\
\hline AMI & $\mathrm{L}^{*}$ & $\mathrm{~L}$ & $\mathrm{H}$ & $\mathrm{H}^{*}$ & $\mathrm{H}-\mathrm{L}$ & $\mathrm{H}^{*}-\mathrm{L}^{*}$ & $\mathrm{H}-\mathrm{L}$ & $\mathrm{H}^{*}-\mathrm{L}^{*}$ & H-L & $\mathrm{H}^{*}-\mathrm{L}^{*}$ \\
\hline $\begin{array}{c}\text { LQ1 } \\
\text { (Illiquid) }\end{array}$ & -0.216 & -0.202 & -0.004 & 0.008 & - & - & - & - & $\begin{array}{l}.198^{* * *} \\
(117.32)\end{array}$ & $\begin{array}{l}.223 * * * \\
(52.30)\end{array}$ \\
\hline $\begin{array}{c}\text { LQ3 } \\
\text { (Liquid) }\end{array}$ & -0.132 & -0.064 & 0.026 & 0.025 & - & - & - & - & $\begin{array}{l}.090^{* * *} \\
(22.66)\end{array}$ & $\begin{array}{l}.156^{* * *} \\
(15.47)\end{array}$ \\
\hline $\begin{array}{c}L Q 3- \\
L Q 1 \\
\end{array}$ & $\begin{array}{l}.084 \\
(2.37) \\
\end{array}$ & $\begin{array}{l}.139 * * * \\
(27.92)\end{array}$ & $\begin{array}{l}.030^{* *} \\
(4.74) \\
\end{array}$ & $\begin{array}{l}.017 \\
(0.60) \\
\end{array}$ & & & & & & \\
\hline
\end{tabular}




\begin{tabular}{|c|c|c|c|c|c|c|c|c|c|c|}
\hline \multirow{2}{*}{$\begin{array}{l}\text { A.4a } \\
\text { ToR }\end{array}$} & \multicolumn{4}{|c|}{ F-Score portfolios, mean IA returns } & \multicolumn{2}{|c|}{$\begin{array}{c}\text { F-Score strategy } \\
\text { returns, } t \text {-test }\end{array}$} & \multicolumn{2}{|c|}{$\begin{array}{c}\text { F-Score strategy } \\
\text { MWW test }\end{array}$} & \multicolumn{2}{|c|}{ Mood } \\
\hline & $\mathrm{L}^{*}$ & $\mathrm{~L}$ & $\mathrm{H}$ & $\mathrm{H}^{*}$ & $\mathrm{H}-\mathrm{L}$ & $\mathrm{H}^{*}-\mathrm{L}^{*}$ & $\mathrm{H}-\mathrm{L}$ & $\mathrm{H}^{*}-\mathrm{L}^{*}$ & $\mathrm{H}-\mathrm{L}$ & $\mathrm{H}^{*}-\mathrm{L}^{*}$ \\
\hline $\begin{array}{c}\text { LQ1 } \\
\text { (Illiquid) }\end{array}$ & -0.191 & -0.148 & 0.046 & 0.074 & $\begin{array}{l}.194^{* * * *} \\
(8.96)\end{array}$ & $\begin{array}{l}.265^{* * * *} \\
(7.22)\end{array}$ & {$[11.78]^{* * *}$} & {$[9.08]^{* * *}$} & - & - \\
\hline $\begin{array}{c}\text { LQ3 } \\
\text { (Liquid) }\end{array}$ & -0.096 & -0.061 & 0.039 & 0.051 & $\begin{array}{l}.100^{* * *} \\
(5.49)\end{array}$ & $\begin{array}{l}.147^{* * *} \\
(4.17)\end{array}$ & {$[8.53]^{* * *}$} & {$[5.87]^{* * *}$} & - & - \\
\hline $\begin{array}{l}\text { LQ3- } \\
\text { LQ1 }\end{array}$ & $.095 * *$ & $.088 * * *$ & -.006 & -.023 & & & & & & \\
\hline $\begin{array}{l}\text { t-test } \\
\text { MWW }\end{array}$ & $\begin{array}{c}(2.33) \\
{[2.85]^{* * *}}\end{array}$ & $\begin{array}{c}(3.79) \\
{[5.01]^{* * *}}\end{array}$ & $\begin{array}{r}(-0.39) \\
{[-0.89]}\end{array}$ & $\begin{array}{c}(-0.73) \\
{[-0.30]}\end{array}$ & & & & & & \\
\hline$\underline{\mathrm{A.4b}}$ & $F-S c o$ & re portfoli & , mediar & returns & & & & $\boldsymbol{W}$ & $\begin{array}{l}\text { F-Scor } \\
\text { return }\end{array}$ & $\begin{array}{l}\text { strategy } \\
\text { Mood }\end{array}$ \\
\hline ToR & $\mathrm{L}^{*}$ & $\mathrm{~L}$ & $\mathrm{H}$ & $\mathrm{H}^{*}$ & $\mathrm{H}-\mathrm{L}$ & $\mathrm{H}^{*}-\mathrm{L}^{*}$ & $\mathrm{H}-\mathrm{L}$ & $\mathrm{H}^{*}-\mathrm{L}^{*}$ & $\mathrm{H}-\mathrm{L}$ & $\mathrm{H}^{*}-\mathrm{L}^{*}$ \\
\hline $\begin{array}{c}\text { LQ1 } \\
\text { (Illiquid) }\end{array}$ & -0.264 & -0.220 & -0.003 & -0.013 & - & - & - & - & $\begin{array}{l}.217 * * * \\
(94.70)\end{array}$ & $\begin{array}{l}.250^{* * *} \\
(59.14)\end{array}$ \\
\hline $\begin{array}{c}\text { LQ3 } \\
\text { (Liquid) }\end{array}$ & -0.165 & -0.123 & 0.012 & 0.015 & - & - & - & - & $\begin{array}{l}.135^{* * *} \\
(54.57)\end{array}$ & $\begin{array}{l}.180 * * * \\
(28.93)\end{array}$ \\
\hline $\begin{array}{c}L Q 3- \\
L Q 1\end{array}$ & $\begin{array}{l}.098^{*} \\
(5.88)\end{array}$ & $\begin{array}{l}.098^{* * *} \\
(19.08)\end{array}$ & $\begin{array}{l}.015 \\
(1.30)\end{array}$ & $\begin{array}{l}.028 \\
(0.56)\end{array}$ & & & & & & \\
\hline
\end{tabular}

Notes: This Table follows a similar format to Panel A.1 and A.2 of Tables 4-7. The main difference is that returns are industry adjusted (IA) by the mean market adjusted return of firms in the same industry in the same year. Industry adjustment is at the ICB level 4 industry classification. The winsorized mean and median is reported for Financial strength measured by the F-Score. Portfolios are independently sorted on Financial strength and then on either IU or Liquidity. The first section of columns contain portfolio returns. In the remaining columns of the table the performance as financial strength strategy returns and associated tests are reported. All returns are reported in decimals. Full details are provided in the notes to Tables 4-7.

Table 10. Time-series portfolio performance and Sharpe ratios (1994-2010).

\begin{tabular}{|c|c|c|c|c|c|c|}
\hline$\underline{\mathrm{A.1}}$ & \multicolumn{3}{|c|}{$F-S c o r e$ strategy $H-L$} & \multicolumn{3}{|c|}{ F-rank strategy $\mathrm{H}-\mathrm{L}$} \\
\hline SDF & Return & SD & Sharpe & Return & SD & Sharpe \\
\hline IU1 (Low) & .124 & .108 & 1.16 & .075 & .102 & 0.74 \\
\hline IU3 (High) & .154 & .183 & 0.84 & .100 & .117 & 0.85 \\
\hline$\underline{\mathrm{A} .2}$ & \multicolumn{3}{|c|}{ F-Score strategy $\mathrm{H}-\mathrm{L}$} & \multicolumn{3}{|c|}{ F-rank strategy $\mathrm{H}-\mathrm{L}$} \\
\hline MADF & Return & $\mathrm{SD}$ & Sharpe & Return & SD & Sharpe \\
\hline IU1 (Low) & .144 & .087 & 1.65 & .097 & .075 & 1.29 \\
\hline IU3 (High) & .168 & .196 & 0.86 & .113 & .126 & 0.90 \\
\hline$\underline{\mathrm{A.3}}$ & \multicolumn{3}{|c|}{$F-$ Score strategy $H-L$} & \multicolumn{3}{|c|}{ F-rank strategy $H-L$} \\
\hline$\overline{\mathrm{AMI}}$ & Return & $\mathrm{SD}$ & Sharpe & Return & SD & Sharpe \\
\hline LQ1 (Illiquid) & .168 & .144 & 1.17 & .117 & .122 & 0.96 \\
\hline LQ3 (Liquid) & .100 & .098 & 1.02 & .081 & .119 & 0.68 \\
\hline$\underline{\mathrm{A} .4}$ & \multicolumn{3}{|c|}{ F-Score strategy $\mathrm{H}-\mathrm{L}$} & \multicolumn{3}{|c|}{ F-rank strategy $H-L$} \\
\hline$\overline{\mathrm{ToR}}$ & Return & SD & Sharpe & Return & SD & Sharpe \\
\hline LQ1 (Illiquid) & .217 & .135 & 1.61 & .175 & .130 & 1.34 \\
\hline LQ3 (Liquid) & .108 & .126 & 0.85 & .056 & .077 & 0.73 \\
\hline
\end{tabular}

Notes: This table summarises the performance of the financial strength strategies over the 1994-2010 accounting data period. Each year firms are assigned to relevant portfolios and one-year buy and hold returns are calculated from June of the year after the accounting data $(t+1)$ through to the end of the following June $(t+2)$. The portfolio return is then averaged across the firms in that period and a time series created. The financial strength (zero net investment) strategy return for each year is the difference between the high financial strength $(\mathrm{H})$ and low financial strength (L) returns for firms with a given level of information uncertainty (IU) or liquidity (LQ). Return is the time-series average of the 17 annual returns corresponding to the 1994-2010 accounting data. SD is the time-series standard deviation. Sharpe is the Sharpe ratio of the strategy calculated as the Return divided by SD. 
Table 11. Determinants of returns.

\begin{tabular}{|c|c|c|c|c|c|c|c|}
\hline \multicolumn{8}{|c|}{ POOLED Regressions of RETURN on Financial Strength, Liquidity and Information Uncertainty } \\
\hline \multicolumn{8}{|c|}{ Panel A: FULL SAMPLE - F-Score dummy } \\
\hline \multirow{4}{*}{ F-Score } & Model 0 & Model 1 & Model 2 & Model 3 & Model 4 & Model 5 & Model 6 \\
\hline & Uncond. & $\mathrm{X}=\mathrm{AMI}$ & $\mathrm{X}=\mathrm{ToR}$ & $\mathrm{X}=\mathrm{AvLQ}$ & $\mathrm{X}=\mathrm{SDF}$ & $\mathrm{X}=\mathrm{MADF}$ & $\mathrm{X}=\mathrm{AvIU}$ \\
\hline & $0.063 * * *$ & $0.066^{* * *}$ & $0.080^{* * *}$ & $0.077 * * *$ & $0.029 * * *$ & $0.033^{* * *}$ & $0.030 * * *$ \\
\hline & 9.23 & 4.17 & 5.70 & 4.73 & 2.36 & 2.67 & 2.45 \\
\hline \multirow[t]{2}{*}{$\mathrm{X}$} & & $0.052 * * *$ & $0.103 * * *$ & $0.102 * * *$ & $-0.046 * * *$ & $-0.044 * * *$ & $-0.045^{* * *}$ \\
\hline & & 3.45 & 6.95 & 6.20 & -3.14 & -3.01 & -3.10 \\
\hline \multirow[t]{2}{*}{$\mathrm{X} * \mathrm{~F}-\mathrm{Score}$} & & -0.005 & -0.032 & -0.030 & $0.069 * * *$ & $0.063^{* * *}$ & $0.067 * * *$ \\
\hline & & -0.21 & -1.30 & -1.07 & 2.80 & 2.55 & 2.70 \\
\hline \multirow[t]{2}{*}{$\mathrm{BM}$} & $-0.117 * * *$ & $-0.134 * * *$ & $-0.133 * * *$ & $-0.137 * * *$ & $-0.107 * * *$ & $-0.108 * * *$ & $-0.108 * * *$ \\
\hline & -7.44 & -7.52 & -7.76 & -7.84 & -6.77 & -6.80 & -6.78 \\
\hline \multirow[t]{2}{*}{ Lag Ret } & $0.063^{* * *}$ & $0.065^{* * *}$ & $0.061^{* * *}$ & $0.062 * * *$ & $0.0624^{* * *}$ & $0.0627^{* * *}$ & $0.0626^{* * *}$ \\
\hline & 7.06 & 6.94 & 6.45 & 6.63 & 6.96 & 7.00 & 6.98 \\
\hline R-sq & 0.016 & 0.018 & 0.020 & 0.020 & 0.017 & 0.017 & 0.017 \\
\hline Nobs & 17,010 & 15,008 & 15,082 & 15,008 & 17,010 & 17,010 & 17,010 \\
\hline \multicolumn{8}{|c|}{ Panel B: FULL SAMPLE - F-rank dummy } \\
\hline \multirow{4}{*}{ F-rank } & Model 0 & Model 1 & Model 2 & Model 3 & Model 4 & Model 5 & Model 6 \\
\hline & Uncond. & $\mathrm{X}=\mathrm{AMI}$ & $\mathrm{X}=\mathrm{ToR}$ & $\mathrm{X}=\mathrm{AvLQ}$ & $\mathrm{X}=\mathrm{SDF}$ & $\mathrm{X}=\mathrm{MADF}$ & $\mathrm{X}=\mathrm{AvIU}$ \\
\hline & $0.042 * * *$ & $0.045 * * *$ & $0.073 * * *$ & $0.065 * * *$ & $0.036^{* * *}$ & $0.040 * * *$ & $0.038 * * *$ \\
\hline & 6.38 & 2.85 & 5.32 & 3.96 & 3.07 & 3.33 & 3.18 \\
\hline \multirow[t]{2}{*}{$\mathrm{X}$} & & $0.062 * * *$ & $0.109 * * *$ & $0.110^{* * *}$ & $-0.060 * * *$ & $-0.059 * * *$ & $-0.061 * * *$ \\
\hline & & 4.00 & 7.28 & 6.67 & -4.20 & -4.11 & -4.18 \\
\hline \multirow[t]{2}{*}{$\mathrm{X} * \mathrm{~F}$-rank } & & -0.005 & $-0.057 * *$ & -0.043 & 0.011 & 0.005 & 0.008 \\
\hline & & -0.20 & -2.33 & -1.52 & 0.49 & 0.20 & 0.35 \\
\hline \multirow[t]{2}{*}{$\mathrm{BM}$} & $-0.124 * * *$ & $-0.141^{* * *}$ & $-0.139 * * *$ & $-0.143^{* * *}$ & $-0.111^{* * *}$ & $-0.111^{* * *}$ & $-0.111^{* * *}$ \\
\hline & -7.83 & -7.93 & -8.05 & -8.18 & -6.90 & -6.92 & -6.90 \\
\hline \multirow[t]{2}{*}{ Lag Ret } & $0.068^{* * *}$ & $0.069 * * *$ & $0.065^{* * *}$ & $0.066^{* * *}$ & $0.066^{* * *}$ & $0.066^{* * *}$ & $0.066^{* * *}$ \\
\hline & 7.47 & 7.27 & 6.78 & 6.91 & 7.29 & 7.32 & 7.30 \\
\hline $\mathrm{R}$-sq & 0.013 & 0.016 & 0.019 & 0.018 & 0.015 & 0.015 & 0.015 \\
\hline Nobs & 16,787 & 14,840 & 14,987 & 14,840 & 16,787 & 16,787 & 16,787 \\
\hline
\end{tabular}

Notes: We estimate: $R_{i t+1}=\propto+\beta_{i} F S_{i t}+\beta_{2} X_{i t}+\beta_{3} F S_{i t} X_{i t}+\sum_{j=1}^{J} \gamma_{j} Z_{j i t}+\varepsilon_{i t}$

$\mathrm{R}$ is the annual market-adjusted return. FS is a financial strength indicator, either the F-Score (F) or F-rank (Frank). FS is a dummy for the F-Score which is 1 if F-Score is H, 0 if F-Score is M and -1 if F-Score is L. Frank is a dummy for the F-rank which is 1 if $\mathrm{F}$-rank is $\mathrm{H}$ (top 20\% each year), 0 if F-rank is $\mathrm{M}$ and -1 if F-rank is $\mathrm{L}$ (bottom $20 \%$ each year). $\mathrm{X}$ is either a liquidity or information uncertainty measures. $\mathrm{X}$ variables are continuous measures bounded between 0 and 1 . The measure is based on the percentile rank within each year. Amihud ratio (AMI) and Turnover ratio (ToR) are 0 for illiquid and 1 for liquid. SDF and MADF are 0 for low uncertainty and 1 for high uncertainty. $Z$ covers control variables especially for book-market ratio (BM) and momentum effects (Lag Ret). $\mathrm{BM}$ is the book-market ratio is the percentile rank and is measured continuously where 0 is the highest BM and 1 is the lowest BM. Lag Ret is the annual market adjusted return in the previous year. Standard errors are adjusted for clusters at the firm level. Nobs is the number of observations. 
Table 12. Determinants of returns - industry-adjusted returns.

\begin{tabular}{|c|c|c|c|c|c|c|c|}
\hline \multicolumn{8}{|c|}{ POOLED Regressions of RETURN on Financial Strength, Liquidity and Information Uncertainty } \\
\hline \multicolumn{8}{|c|}{ Panel A: FULL SAMPLE - F-Score dummy } \\
\hline \multirow{4}{*}{ F-Score } & Model 0 & Model 1 & Model 2 & Model 3 & Model 4 & Model 5 & Model 6 \\
\hline & Uncond. & $\mathrm{X}=\mathrm{AMI}$ & $X=$ ToR & $X=A v L Q$ & $\mathrm{X}=\mathrm{SDF}$ & $\mathrm{X}=\mathrm{MADF}$ & $\mathrm{X}=\mathrm{AvIU}$ \\
\hline & $0.055^{* * *}$ & $0.065 * * *$ & $0.076^{* * *}$ & $0.076^{* * *}$ & $0.021 *$ & $0.033^{* *}$ & $0.023^{*}$ \\
\hline & 8.51 & 4.26 & 5.67 & 4.85 & 1.80 & 2.20 & 1.95 \\
\hline \multirow[t]{2}{*}{$\mathrm{X}$} & & $0.046^{* * *}$ & $0.095^{* * *}$ & $0.092 * * *$ & $-0.043 * * *$ & $-0.040 * * *$ & $-0.042 * * *$ \\
\hline & & 3.16 & 6.71 & 5.86 & -3.09 & -2.86 & -3.00 \\
\hline \multirow{2}{*}{$X^{*}$ F-Score } & & -0.020 & -0.040 & -0.044 & $0.069 * * *$ & $0.061^{* *}$ & $0.066^{* * *}$ \\
\hline & & -0.82 & $-1.69 *$ & $-1.65^{*}$ & 2.85 & 2.52 & 2.71 \\
\hline \multirow[t]{2}{*}{$\mathrm{BM}$} & $-0.111 * * *$ & $-0.119 * * *$ & $-0.133 * * *$ & $-0.122 * * *$ & $-0.102 * * *$ & $-0.103 * * *$ & $-0.102 * * *$ \\
\hline & -7.40 & -7.00 & -7.31 & -7.32 & -6.73 & -6.77 & -6.74 \\
\hline \multirow[t]{2}{*}{ Lag Ret } & $0.061 * * *$ & $0.064 * * *$ & $0.059 * * *$ & $0.061 * * *$ & $0.0604 * * *$ & $0.0608^{* * *}$ & $0.0606^{* * *}$ \\
\hline & 6.65 & 6.53 & 6.09 & 6.25 & 6.54 & 6.58 & 6.56 \\
\hline R-sq & 0.014 & 0.016 & 0.018 & 0.018 & 0.016 & 0.015 & 0.015 \\
\hline Nobs & 17,010 & 15,008 & 15,082 & 15,008 & 17,010 & 17,010 & 17,010 \\
\hline \multicolumn{8}{|c|}{ Panel B: FULL SAMPLE - F-rank dummy } \\
\hline \multirow{4}{*}{ F-rank } & Model 0 & Model 1 & Model 2 & Model 3 & Model 4 & Model 5 & Model 6 \\
\hline & Uncond. & $\mathrm{X}=\mathrm{AMI}$ & $X=$ ToR & $\mathrm{X}=\mathrm{AvLQ}$ & $\mathrm{X}=\mathrm{SDF}$ & $\mathrm{X}=\mathrm{MADF}$ & $\mathrm{X}=\mathrm{AvIU}$ \\
\hline & $0.036^{* * *}$ & $0.044 * * *$ & $0.071^{* * *}$ & $0.064 * * *$ & $0.029 * * *$ & $0.034^{* * *}$ & $0.032 * * *$ \\
\hline & 5.63 & 2.87 & 5.45 & 4.12 & 2.59 & 2.95 & 2.74 \\
\hline \multirow[t]{2}{*}{$\mathrm{X}$} & & $0.052 * * *$ & $0.100 * * *$ & $0.098 * * *$ & $-0.056 * * *$ & $-0.053 * * *$ & $-0.055^{* * *}$ \\
\hline & & 3.58 & 7.00 & 6.22 & -4.00 & -3.81 & -3.93 \\
\hline \multirow[t]{2}{*}{$\mathrm{X} * \mathrm{~F}$-rank } & & -0.016 & $-0.066^{* * *}$ & $-0.055^{* *}$ & 0.012 & 0.004 & 0.008 \\
\hline & & -0.64 & -2.82 & -2.07 & 0.52 & 0.15 & 0.34 \\
\hline \multirow[t]{2}{*}{ BM } & $-0.116^{* * *}$ & $-0.125 * * *$ & $-0.124^{* * *}$ & $-0.127 * * *$ & $-0.105^{* * *}$ & $-0.105^{* * *}$ & $-0.105^{* * *}$ \\
\hline & -7.71 & -7.36 & -7.54 & -7.62 & -6.82 & -6.85 & -6.82 \\
\hline \multirow[t]{2}{*}{ Lag Ret } & $0.065 * * *$ & $0.068^{* * *}$ & $0.063^{* * *}$ & $0.064 * * *$ & $0.064 * * *$ & $0.064^{* * *}$ & $0.064^{* * *}$ \\
\hline & 7.01 & 6.82 & 6.36 & 6.49 & 6.83 & 6.86 & 6.84 \\
\hline R-sq & 0.012 & 0.016 & 0.017 & 0.016 & 0.013 & 0.013 & 0.013 \\
\hline Nobs & 16,787 & 14,840 & 14,987 & 14,840 & 16,787 & 16,787 & 16,787 \\
\hline
\end{tabular}

Notes: We estimate: $R_{I A, i t+1}=\propto+\beta_{i} F S_{i t}+\beta_{2} X_{i t}+\beta_{3} F S_{i t} X_{i t}+\sum_{j=1}^{J} \gamma_{j} Z_{j i t}+\varepsilon_{i t}$

$\mathrm{R}_{\mathrm{IA}}$ is the annual industry-adjusted return. Returns are industry adjusted (IA) by the mean market adjusted return of firms in the same industry in the same year. Industry adjustment is at the ICB level 4 industry classification. FS is a financial strength indicator, either the F-Score (F) or F-rank (Frank). FS is a dummy for the F-Score which is 1 if F-Score is H, 0 if F-Score is M and -1 if F-Score is L. Frank is a dummy for the F-rank which is 1 if F-rank is $\mathrm{H}$ (top $20 \%$ each year), 0 if F-rank is $\mathrm{M}$ and -1 if F-rank is $\mathrm{L}$ (bottom $20 \%$ each year). $\mathrm{X}$ is either a liquidity or information uncertainty measures. $\mathrm{X}$ variables are continuous measures bounded between 0 and 1 . The measure is based on the percentile rank within each year. Amihud ratio (AMI) and Turnover ratio (ToR) are 0 for illiquid and 1 for liquid. SDF and MADF are 0 for low uncertainty and 1 for high uncertainty. Z covers control variables especially for book-market ratio (BM) and momentum effects (Lag Ret). BM is the book-market ratio is the percentile rank and is measured continuously where 0 is the highest BM and 1 is the lowest BM. Lag Ret is the annual market adjusted return in the previous year. Standard errors are adjusted for clusters at the firm level. Nobs is the number of observations. 
POOLED Regressions of RETURN on Liquidity and Information Uncertainty Panel A: SUB SAMPLE - F-Score low

$\mathrm{X}$

$\mathrm{BM}$

Lag Ret

R-sq

Nobs

2,500

2,507

2,500

2,695

2,695

2,695

\begin{tabular}{|c|c|c|c|c|c|c|}
\hline \multicolumn{2}{|c|}{ Panel C: SUB SAMPLE - F-Score high } & \multicolumn{2}{|c|}{ 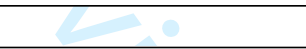 } & \multirow{3}{*}{$\begin{array}{l}\text { Model } 4 \\
\mathrm{X}=\mathrm{SDF}\end{array}$} & \multirow{3}{*}{$\begin{array}{c}\text { Model } 5 \\
\mathrm{X}=\mathrm{MADF}\end{array}$} & \multirow{3}{*}{$\begin{array}{l}\text { Model } 6 \\
\mathrm{X}=\text { AvIU }\end{array}$} \\
\hline \multirow{4}{*}{$\mathrm{X}$} & Model 1 & Model 2 & Model 3 & & & \\
\hline & $\mathrm{X}=\mathrm{AMI}$ & $\mathrm{X}=\mathrm{TOR}$ & $X=A v L Q$ & & & \\
\hline & 0.001 & 0.042 & 0.029 & 0.016 & 0.014 & 0.016 \\
\hline & 0.03 & 1.33 & 0.75 & 0.47 & 0.41 & 0.44 \\
\hline \multirow[t]{2}{*}{$\mathrm{BM}$} & $-0.205^{*}$ & $-0.078 * *$ & $-0.080 * *$ & $-0.093 * * *$ & $-0.093 * * *$ & $-0.093 * * *$ \\
\hline & -1.80 & -2.16 & -2.07 & -3.01 & -3.00 & -3.01 \\
\hline \multirow[t]{2}{*}{ Lag Ret } & 0.031 & 0.029 & 0.031 & $0.035^{*}$ & $0.035^{*}$ & $0.035^{*}$ \\
\hline & 1.49 & 1.42 & 1.47 & 1.80 & 1.80 & 1.80 \\
\hline R-sq & 0.00 & 0.00 & 0.00 & 0.00 & 0.00 & 0.00 \\
\hline Nobs & 2,628 & 2,640 & 2,628 & 3,081 & 3,081 & 3,081 \\
\hline \multicolumn{7}{|c|}{ Panel D: SUB SAMPLE - F-rank high } \\
\hline \multirow{4}{*}{$\mathrm{X}$} & Model 1 & Model 2 & Model 3 & Model 4 & Model 5 & Model 6 \\
\hline & $\mathrm{X}=\mathrm{AMI}$ & $\mathrm{X}=\mathrm{TOR}$ & $X=A v L Q$ & $\mathrm{X}=\mathrm{SDF}$ & $\mathrm{X}=\mathrm{MADF}$ & $\mathrm{X}=\mathrm{AvIU}$ \\
\hline & 0.009 & 0.050 & 0.039 & -0.031 & -0.038 & -0.035 \\
\hline & 0.21 & 1.41 & 0.92 & -0.90 & -1.11 & -1.01 \\
\hline \multirow[t]{2}{*}{$\mathrm{BM}$} & $-0.097 * *$ & $-0.101 * * *$ & $-0.103 * * *$ & $-0.088^{* * *}$ & $-0.088 * * *$ & $-0.088^{* * *}$ \\
\hline & -2.47 & -2.81 & -2.71 & -2.76 & -2.76 & -2.75 \\
\hline \multirow[t]{2}{*}{ Lag Ret } & 0.036 & 0.032 & 0.034 & 0.036 & 0.036 & 0.036 \\
\hline & 1.70 & 1.52 & 1.63 & 1.85 & 1.84 & 1.85 \\
\hline R-sq & 0.000 & 0.000 & 0.005 & 0.000 & 0.000 & 0.000 \\
\hline Nobs & 2,912 & 2,931 & 2,912 & 3,424 & 3,424 & 3,424 \\
\hline
\end{tabular}

Notes: See Table 11 for variable descriptions. Dependent variable is the market-adjusted return. The regressions are estimated for sub-samples of either low financial strength (panels A and B) or high financial strength (panels C and D) firms. 